\title{
The Ozone Monitoring Instrument: overview of 14 years in space
}

\author{
Pieternel F. Levelt $^{1,2}$, Joanna Joiner ${ }^{3}$, Johanna Tamminen ${ }^{4}$, J. Pepijn Veefkind ${ }^{1,2}$, Pawan K. Bhartia ${ }^{3}$, \\ Deborah C. Stein Zweers ${ }^{1}$, Bryan N. Duncan ${ }^{3}$, David G. Streets ${ }^{5}$, Henk Eskes ${ }^{1}$, Ronald van der $\mathbf{A}^{1}$, Chris McLinden ${ }^{6}$, \\ Vitali Fioletov $^{6}$, Simon Carn ${ }^{7}$, Jos de Laat ${ }^{1}$, Matthew DeLand ${ }^{8}$, Sergey Marchenko ${ }^{8}$, Richard McPeters ${ }^{3}$, \\ Jerald Ziemke $^{3,9}$, Dejian Fu ${ }^{10}$, Xiong Liu ${ }^{11}$, Kenneth Pickering ${ }^{3,12}$, Arnoud Apituley ${ }^{1}$, Gonzalo González Abad ${ }^{11}$, \\ Antti Arola ${ }^{4}$, Folkert Boersma ${ }^{1,13}$, Christopher Chan Miller ${ }^{11}$, Kelly Chance ${ }^{11}$, Martin de Graaf ${ }^{1}$, \\ Janne Hakkarainen ${ }^{4}$, Seppo Hassinen ${ }^{4}$, Iolanda Ialongo ${ }^{4}$, Quintus Kleipool ${ }^{1}$, Nickolay Krotkov ${ }^{3}$, Can Li $^{12}$, \\ Lok Lamsal $^{14}$, Paul Newman ${ }^{3}$, Caroline Nowlan ${ }^{11}$, Raid Suleiman ${ }^{11}$, Lieuwe Gijsbert Tilstra ${ }^{1}$, Omar Torres ${ }^{3}$, \\ Huiqun Wang ${ }^{11}$, and Krzysztof Wargan ${ }^{3,8}$ \\ ${ }^{1}$ Royal Netherlands Meteorological Institute, De Bilt, 3731 GA, the Netherlands \\ ${ }^{2}$ Faculty of Civil Engineering and Geosciences, University of Technology Delft, Delft, $2628 \mathrm{CN}$, the Netherlands \\ ${ }^{3}$ NASA Goddard Space Flight Center, Greenbelt, Maryland 20771, USA \\ ${ }^{4}$ Finnish Meteorological Institute, Helsinki, 00101, Finland \\ ${ }^{5}$ Energy Systems Division, Argonne National Laboratory, Argonne, Illinois 60439, USA \\ ${ }^{6}$ Air Quality Research Division, Environment and Climate Change Canada, Toronto, M3H 5T4, Canada \\ ${ }^{7}$ Geological and Mining Engineering and Sciences, Michigan Technological University, Houghton, Michigan 49931, USA \\ ${ }^{8}$ Science Systems and Applications, Inc., Lanham, Maryland 20706, USA \\ ${ }^{9}$ Goddard Earth Sciences Technology and Research (GESTAR), Morgan State University, Baltimore, Maryland, USA \\ ${ }^{10}$ NASA Jet Propulsion Laboratory, Pasadena, California 91109, USA \\ ${ }^{11}$ Harvard-Smithsonian Center for Astrophysics, Cambridge, Massachusetts 02138, USA \\ ${ }^{12}$ Department of Atmospheric and Oceanic Sciences, University of Maryland, College Park, Maryland 20742, USA \\ ${ }^{13}$ Department of Environmental Sciences, Wageningen University, Wageningen, 6708 PB, the Netherlands \\ ${ }^{14}$ Universities Space Research Association, Columbia, Maryland 21046, USA
}

Correspondence: Pieternel F. Levelt (levelt@knmi.nl)

Received: 29 May 2017 - Discussion started: 20 July 2017

Revised: 9 February 2018 - Accepted: 27 February 2018 - Published: 24 April 2018

\begin{abstract}
This overview paper highlights the successes of the Ozone Monitoring Instrument (OMI) on board the Aura satellite spanning a period of nearly 14 years. Data from OMI has been used in a wide range of applications and research resulting in many new findings. Due to its unprecedented spatial resolution, in combination with daily global coverage, OMI plays a unique role in measuring trace gases important for the ozone layer, air quality, and climate change. With the operational very fast delivery (VFD; direct readout) and near real-time (NRT) availability of the data, OMI also plays an important role in the development of operational services in the atmospheric chemistry domain.
\end{abstract}

\section{Introduction}

On 15 July 2004, the Dutch-Finnish Ozone Monitoring Instrument (OMI) was launched on board the US National Aeronautics and Space Administration (NASA) Earth Observing System (EOS) Aura spacecraft. After nearly 14 years of operations, OMI still continues to provide unique data for atmospheric research and applications. In this overview paper that is part of the ACP/AMT OMI special issue, we aim to highlight OMI's exceptional instrument design features, as well as some of OMI's accomplishments. Detailed results can be found in other contributions in this special issue, and in other publications. We note, given OMI's broad, worldwide user community, that it is impossible to provide a com- 
plete overview of all the achievements obtained using OMI data.

In addition to being a successful instrument, the OMI project has also brought together the research communities from the United States with expertise from the Total Ozone Mapping Spectrometer (TOMS; Heath et al., 1975; McPeters et al., 1998) and the Solar Backscatter Ultraviolet (SBUV; Cebula et al., 1988) instruments and European expertise based on the Global Ozone Monitoring Experiment (GOME; Burrows et al., 1999) and the SCanning Imaging Absorption spectroMeter for Atmospheric CHartographY (SCIAMACHY; Bovensmann et al., 1999).

This paper is organized as follows. In the introduction we present the OMI science questions, the data products, inflight performance, and the instrument design features. The sections after the introduction cover the following themes:

- air quality monitoring, air quality forecasting, pollution events, and trends;

- top-down emission estimates;

- monitoring of volcanoes;

- monitoring of the spectral solar irradiance;

- Montreal Protocol, total ozone, and UV radiation;

- tropospheric ozone;

- research data products;

- multi-platform products and analyses;

- aircraft and field campaigns.

\subsection{OMI scientific objectives met and exceeded}

At the start of the OMI project, the following four science questions were defined:

1. Is the ozone layer recovering as expected?

2. What are the sources of aerosols and trace gases that affect global air quality and how are they transported?

3. What are the roles of tropospheric ozone and aerosols in climate change?

4. What are the causes of surface ultraviolet B (UVB) change?

The first question was the main objective at the start of the OMI project. The OMI instrument has turned out to be very stable and provides a long-term data record for monitoring the ozone layer, which is critical for the assessment of the Montreal Protocol. As will be discussed in Sect. 6, the OMI data record covers a period during which further ozone depletion stopped and the probable onset of recovery is observable.
The second science question deals with air quality where OMI has clearly exceeded expectations. By its frequent observations of trace gases such as nitrogen dioxide $\left(\mathrm{NO}_{2}\right)$, sulfur dioxide $\left(\mathrm{SO}_{2}\right)$, and formaldehyde (HCHO), OMI contributed to research regarding the mapping of sources and transport of pollution. Note that this question focuses primarily on the sources and transport. It was not known prelaunch how well OMI would perform quantitatively in terms of estimating emissions and their trends. As we will show in Sects. 2 through 4, OMI has exceeded expectations with respect to estimating emissions and monitoring of trends. This has lead to the ability to link trends in air quality with policy measures. The OMI data show a steady decline in concentrations of $\mathrm{NO}_{2}$ in the United States, Europe, and Japan, whereas in China, first strong increases were observed, followed by decreases after 2014. These improvements can all be linked to the success of policy measures.

The third science objective considers the contribution of OMI to climate research by observing tropospheric ozone - a greenhouse gas - and aerosols, which mainly act as cooling agents, although OMI is best at detecting absorbing aerosol that can cause warming. Here again, OMI has exceeded expectations in terms of its ability to detect trends as part of longer multi-instrument data records. Tropospheric ozone can be derived from the OMI data alone (Sect. 7) or in combination with the Microwave Limb Sounder (MLS) and Tropospheric Emission Spectrometer (TES) instruments also on board the Aura platform as well as the Atmospheric Infrared Sounder (AIRS) on the EOS Aqua satellite that flies in formation with Aura. In both methods, it is important that a long-term data record of tropospheric ozone has been established. For aerosols, the focus has been on the absorption that can be derived using the ultraviolet (UV) channel. In combination with the TOMS, GOME, and SCIAMACHY data, this is one of the longest aerosol data records available. Observation of $\mathrm{SO}_{2}$ are also linked to aerosols as $\mathrm{SO}_{2}$ is an important precursor for aerosol particles. The observations show that in the many parts of the world $\mathrm{SO}_{2}$ is decreasing. However, in India we still observe strong increases due to the growing economy and the limited emissions control measures. Natural emissions of $\mathrm{SO}_{2}$ and aerosols from volcanoes have also been monitored by OMI in great detail (Sect. 4).

The last science question on the surface UVB change is strongly linked to the long-term total ozone record. Again, OMI has been successful particularly within the context of long-term records that span decades covered by a series of UV sensors. Research has focused on cases of high UV doses due to low total ozone (de Laat et al., 2010), showing a link in springtime polar ozone loss with UVB in the following summer in the extratropics (Karpechko et al., 2013), and on explaining the differences between UV dose derived from satellite and that measured on ground (Bernhard et al., 2015).

Although OMI was conceived as a research instrument, it also contributes to several operational applications. These applications make use of two data streams: the near real- 
time (NRT) data available within $3 \mathrm{~h}$ of sensing and veryfast-delivery (VFD) data available within $20 \mathrm{~min}$ of sensing via the direct readout capability. Although these data streams were experimental, they turned out to be very successful. Operational users include the European Centre for Medium-range Weather Forecasts (ECMWF) and the US National Oceanic and Atmospheric Administration (NOAA) for ozone and air quality forecasts, and the Volcanic Ash Advisory Centers (VAACs) for the rerouting of aircraft in case of a volcanic eruption. The NRT data are provided on the Tropospheric Emission Monitoring Internet Service (TEMIS) website (www.temis.nl, last access: 5 April 2018) for the scientific user community. The VFD images are distributed via the Satellite Measurements from Polar Orbit (SAMPO) website (sampo.fmi.fi, last access: 5 April 2018).

\subsection{Design features}

In this section we describe some of the important new design features of OMI. For a detailed description of the instrument and its in-flight performance, we refer to Levelt et al. (2006a), Dobber et al. (2006), van den Oord et al. (2006), and Schenkeveld et al. (2017) (this issue). OMI combines the spectral capabilities of the previously launched European spectrometers GOME and SCIAMACHY with the daily global mapping capability of NASA's SBUV and TOMS.

OMI is a nadir-looking, push broom ultraviolet/visible (UV/VIS) solar backscatter grating spectrometer that measures the Earth's radiance spectrum from 270 to $500 \mathrm{~nm}$ with a resolution of approximately $0.5 \mathrm{~nm}$ (Levelt et al., 2006a). The $114^{\circ}$ viewing angle of the telescope corresponds to a $2600 \mathrm{~km}$ wide swath on the Earth's surface that enables measurements with a daily global coverage. The light entering the telescope is depolarized using a scrambler and then split into two channels: the UV channel (wavelength range 270$380 \mathrm{~nm})$ and the VIS channel $(350-500 \mathrm{~nm})$. In the normal global operation mode, the OMI pixel size is $13 \times 24 \mathrm{~km}^{2}$ at nadir (along $x$ across track). In addition to observing the Earth, OMI measures the solar irradiance once per day through the solar port.

OMI uses 2-dimensional (2-D) detectors, where on one axis of the detector the across-track ground pixels are imaged and on the other axis the spectral information is recorded. This sensing technique allows for the simultaneous measurement of all the ground pixels in the swath; therefore, OMI does not have a scan mirror. The 2-D detectors enable the combinations of a wide swath, a good spatial resolution, and a high signal-to-noise ratio. The fact that most successor instruments, including the Ozone Mapping and Profiler Suite (OMPS) nadir mapper launched in 2012 on the NASA/NOAA National Polar-orbiting Partnership (NPP) satellite (Flynn et al., 2014), the TROPOspheric Monitoring Instrument (TROPOMI) launched in 2017 on the European Space Agency (ESA) Sentinel-5 Precursor (S5P; Veefkind et al., 2012), and the Environment Monitoring Instrument
(EMI) to be launched in 2018 on the Chinese GaoFen-5 satellite (China Daily, 2018) are using this 2-D imaging technique demonstrates the success of OMI. This technique is also used in the geostationary instruments that are currently in development, including the ESA Sentinel-4 Ultraviolet Visible Near-infrared (UVN) sensor (Ingmann et al., 2012), the Korean Geostationary Environmental Monitoring Spectrometer (GEMS; Kim, 2012), and the NASA Tropospheric Emissions: Monitoring of Pollution (TEMPO; Zoogman et al., 2016) mission. The high spatial resolution of OMI $\left(13 \times 24 \mathrm{~km}^{2}\right.$ at nadir $)$ was one of the key technical achievements that enabled significant advances in air quality research and emission monitoring from space and what motivates new air quality missions like TROPOMI to strive for even higher spatial resolution.

In addition to the 2-D imaging technique, a new feature of OMI compared to GOME and SCIAMACHY is that OMI incorporated the use of a polarization scrambler in a grating spectrometer. The polarization scrambler is applied in the OMI telescope before entering the polarization sensitive spectrograph; this makes the instrument almost insensitive to the polarization of the incoming light. In GOME and SCIAMACHY, the polarization sensitivity is dealt with by measuring the degree of polarization at several wavelengths and applying complex correction algorithms. The OMI approach does not require such corrections, which simplifies the retrieval algorithms. One drawback is that a polarization scrambler can produce small spectral features that affect retrievals, potentially leading to errors in trace gas concentrations. In addition, the use of a polarization scrambler causes uncertainties in the spatial registration of the ground pixels. During the design phase, a careful trade-off between the amount of polarization scrambling, the spectral features, and the spatial registration was made. For the in-flight OMI data, these aspects have never been an issue. In many of the follow-on instruments polarization scramblers are also applied.

Another special feature of the OMI instrument is the type of diffuser used to observe the Sun. Such diffusers are required to reduce the intensity of the solar radiance. In previous instruments, diffusers were made of aluminum or Spectralon. These materials are optically stable but exhibit spectral features that can interfere with trace gas absorptions and thus affect the data quality. OMI has three diffusers that are used separately. Two of them are made of aluminum, whereas one is a new type quartz volume diffuser (QVD). The new QVD had an unknown stability but was known to have smaller spectral features as compared with the aluminum diffusers. Because of its superior spectral behavior, the daily solar observations of OMI use the QVD diffuser that has proven to be very stable. Therefore, the TROPOMI instrument only uses QVD solar diffusers. 


\subsection{In-flight performance}

The in-flight performance is discussed in detail in Schenkeveld et al. (2017). Key aspects of the in-flight performance are the radiometric and spectral stability, the row anomaly, and detector degradation. The radiometric degradation of OMI ranges from $\sim 2 \%$ in the UV channel to $\sim 0.5 \%$ in the VIS channel, which is much lower than any other instrument of its kind. Although it is not possible to reconstruct the causes of the low degradation, we believe that several aspects are important: the cleanliness during the instrument build and integration, the extensive outgassing period after the launch, and the fact that the primary mirror is protected in the instrument housing, instead of located outside the instrument housing which is needed in the case of a scanning mirror.

The one major anomaly of OMI is the so-called rowanomaly (Schenkeveld et al., 2017). A row anomaly is an anomaly that affects the quality of the radiance data at all wavelengths for a particular viewing direction of OMI. This corresponds to a row on the 2-D detectors, and hence the term "row anomaly". The cause for the row anomaly is outside of the instrument; it is most likely caused by damage to the insolation blankets in which OMI is covered, blocking part of the field of view. Although early signs were observed starting in 2007 , the main row anomaly started in 2009. For TROPOMI, the lesson learned was to put an additional aluminum plate over the insolation blankets at the location where the fieldof-view is close to the housing of the instrument.

The OMI 2-D CCDs (charge coupled devices) show several effects due to their exposure to the harsh space environment. First of all, the dark current has increased substantially. Overall, this degradation is as expected and can be corrected by subtracting daily measured dark current maps. However, some of the detector pixels show erratic changes in dark current over time, which is referred to as random telegraph signals (RTS). When the dark current of these pixels changes significantly on timescales of less than 1 day, they cannot be used in retrievals. This effect was known before the launch of OMI from the Global Ozone Monitoring by Occultation of Stars (GOMOS; Betraux et al., 2010) instrument on Envisat. At a late stage of the OMI development the detector temperatures were lowered to $-8{ }^{\circ} \mathrm{C}$ and additional shielding was applied. It is recommended to further reduce the detector temperature to prevent significant effects of RTS. This is especially important for trace gas retrievals with small absorption features such as, for example, formaldehyde.

\subsection{OMI data products}

In Table 1, a list is given of the standard, NRT, and VFD data products. The standard products are available within 2 days after measurement. OMI also provides global NRT data for selected products that are available within $3 \mathrm{~h}$ after measure- ment. The VFD products are available for a limited region ${ }^{1}$ covering most of Europe $20 \mathrm{~min}$ after measurement. The algorithms used to generate the standard and NRT products are all published in peer reviewed papers.

For some OMI level 2 (L2) data products, two standard algorithms have been developed. For example, for ozone there is a differential optical absorption spectroscopy (DOAS) retrieval and a TOMS-type of retrieval. This was considered important to be able to extend the existing DOAS data records from GOME and SCIAMACHY as well as the TOMS data record. At the time OMI was launched, several $\mathrm{NO}_{2}$ retrieval approaches were in development. For OMI, we developed an off-line $\mathrm{NO}_{2}$ algorithm and an algorithm that runs in NRT to support air quality forecasting applications. OMI does not have a separate cloud channel, like the $\mathrm{O}_{2} \mathrm{~A}$ band, used by GOME and SCIAMACHY. Therefore, parallel development was started to ensure that at least one cloud data product would be ready. This resulted in two cloud products, one based on the $\mathrm{O}_{2}-\mathrm{O}_{2}$ absorption band in the VIS channel and the other on rotational-Raman scattering applied in the UV channel. Both turned out to be successful and yield complementary information. As there is a slight difference in alignment of the UV and VIS channels, it also turned out to be beneficial to have cloud retrievals from both channels. Although dual algorithm development might appear counterproductive, or seem confusing because users might not know which product to use, the experience within the OMI community has been of great benefit. A huge advantage of the development of two algorithms, using different physical approaches but the same OMI level 1B (L1B) data set, is the added possibility of verification of the accuracy of the algorithm used and errors related solely to the retrieval technique and not the instrument errors. Additionally, two algorithms can be viewed as a type of ensemble result, a technique widely used in the modeling community to get information on consistency between different modeling forecasts, and in turn the quality of the model forecast. This type of comparison has led to considerable improvements of both algorithms. In recent years, several OMI research data products have been developed, as well as some combined satellite data products (see Sects. 7, 8, and 9). OMI research data products are defined as being processed and applicable for the entire global extent. There are additional regional OMI data products including the European regional $\mathrm{NO}_{2}$ product called EOMINO (Zhou et al., 2010) and the Chinese regional $\mathrm{NO}_{2}$ product, POMINO (Lin et al., 2014). Thus, OMI data products can be classified as standard products (Table 1), research data products (Sect. 8), or as regional data products.

\footnotetext{
${ }^{1}$ VFD products cover roughly an area northwards from northern Italy and Spain and from Greenland in the west to the Ural mountains in the east.
} 
Table 1. OMI standard products along with their type (L1B: radiances and irradiances, L2: orbital data, L3: gridded data) delivery method (S: standard, NRT, or VFD), and principle investigator organization (the Royal Netherlands Meteorological Institute, KNMI; the Finnish Meteorological Institute, FMI; National Aeronautics and Space Administration, NASA; and the Smithsonian Astrophysical Observatory, $\mathrm{SAO})$.

\begin{tabular}{|c|c|c|c|c|}
\hline Product name & $\begin{array}{l}\text { Product } \\
\text { type }\end{array}$ & $\begin{array}{l}\text { Delivery } \\
\text { method }\end{array}$ & $\begin{array}{l}\text { Principal investigator } \\
\text { institute }\end{array}$ & References \\
\hline $\begin{array}{l}\text { Radiances and solar irradiances } \\
\text { (OML1BRUG, OML1BRVG, OML1BRR) }\end{array}$ & L1B & $\mathrm{S}, \mathrm{NRT}$ & KNMI, NASA & Dobber et al. (2007a, b, c, d, e) \\
\hline $\begin{array}{l}\text { Aerosol absorption optical thickness } \\
\text { and type (VIS) (OMAERO) }\end{array}$ & L2, L3 & $S$ & KNMI & Stein Zweers and Veefkind (2012a, b, c) \\
\hline $\begin{array}{l}\text { Aerosol absorption optical depth, and single } \\
\text { scattering albedo (UV) (OMAERUV) }\end{array}$ & L2, L3 & $S$ & NASA & Torres $(2006,2008,2015)$ \\
\hline BrO columns (OMBRO) & $\mathrm{L} 2$ & S & SAO & Chance (2007a) \\
\hline OClO slant column (OMCLO) & $\mathrm{L} 2$ & $\mathrm{~S}$ & SAO & Chance (2007b) \\
\hline $\begin{array}{l}\text { Cloud product } \mathrm{O}_{2}-\mathrm{O}_{2} \text { absorption } \\
\text { (OMCLDO2) }\end{array}$ & $\mathrm{L} 2$ & S, NRT & KNMI & Veefkind (2006a, c, 2007, 2012) \\
\hline $\begin{array}{l}\text { Cloud product rotational } \\
\text { Raman (OMCLDRR) }\end{array}$ & $\mathrm{L} 2$ & S, NRT & NASA & Joiner $(2006,2012)$ \\
\hline HCHO columns (OMHCHO) & $\mathrm{L} 2$ & S & SAO & Chance $(2007 \mathrm{c})$ \\
\hline $\begin{array}{l}\mathrm{NO}_{2} \text { column (standard) } \\
(\mathrm{OMNO} 2)\end{array}$ & $\mathrm{L} 2, \mathrm{~L} 3$ & S & NASA, KNMI & $\begin{array}{l}\text { Krotkov }(2012,2013) \\
\text { Krotkov and Veefkind (2016) }\end{array}$ \\
\hline $\begin{array}{l}\mathrm{NO}_{2} \text { columns } \\
\text { (DOMINO) }\end{array}$ & $\mathrm{L} 2, \mathrm{~L} 3$ & NRT & KNMI & $\begin{array}{l}\text { (http://www.temis.nl/airpollution/no2col, } \\
\text { last access: } 11 \text { April 2018) }\end{array}$ \\
\hline $\begin{array}{l}\mathrm{O}_{3} \text { total column, aerosol index* } \\
\text { (TOMS) (OMTO3) }\end{array}$ & $\mathrm{L} 2, \mathrm{~L} 3$ & S, NRT & NASA & Bhartia $(2005,2012 a, b, c)$ \\
\hline $\begin{array}{l}\mathrm{O}_{3} \text { total column (DOAS) } \\
(\mathrm{OMDOAO})\end{array}$ & $\mathrm{L} 2, \mathrm{~L} 3$ & S, NRT & KNMI & Veefkind $(2006 b, 2012 b, c)$ \\
\hline $\begin{array}{l}\mathrm{O}_{3} \text { profile } \\
(\mathrm{OMO} 3 \mathrm{PR})\end{array}$ & $\mathrm{L} 2$ & $S$ & KNMI & de Haan and Veefkind (2009) \\
\hline $\begin{array}{l}\text { Pixel corners } \\
\text { (OMPIXCOR) }\end{array}$ & $\mathrm{L} 2$ & S & NASA & Kurosu and Celarier $(2010 a, b)$ \\
\hline $\begin{array}{l}\mathrm{SO}_{2} \text { columns } \\
(\mathrm{OMSO} 2)\end{array}$ & $\mathrm{L} 2, \mathrm{~L} 3$ & S, NRT & NASA & $\begin{array}{l}\text { Li et al. (2006), } \\
\text { Krotkov et al. }(2014,2015)\end{array}$ \\
\hline $\begin{array}{l}\text { OMI MODIS merged cloud } \\
\text { (OMMYDCLD) }\end{array}$ & $\mathrm{L} 2$ & $S$ & NASA & Joiner (2014) \\
\hline $\begin{array}{l}\text { OMI indices collocated to MODIS } \\
\text { aerosol products (OMMYDAGEO) }\end{array}$ & $\mathrm{L} 2$ & S & NASA & Joiner (2017) \\
\hline $\begin{array}{l}\text { Surface reflectance } \\
\text { climatology (OMLER) }\end{array}$ & L3 & S & KNMI & Kleipool (2010) \\
\hline Surface UVB (OMUVB) & L2, L3 & S & FMI & Hovila et al. $(2007,2013,2014)$ \\
\hline Total $\mathrm{O}_{3}$ & $\mathrm{~L} 2$ & VFD & FMI, KNMI, NASA & (http://sampo.fmi.fi, last access: 5 April 2018) \\
\hline Effective cloud fraction & $\mathrm{L} 2$ & VFD & FMI, KNMI & (http://sampo.fmi.fi, last access: 5 April 2018) \\
\hline $\begin{array}{l}\text { UV index, erythemal } \\
\text { daily UV dose }\end{array}$ & $\mathrm{L} 2$ & VFD & FMI & (http://sampo.fmi.fi, last access: 5 April 2018) \\
\hline $\mathrm{SO}_{2}$ columns & $\mathrm{L} 2$ & VFD & FMI, NASA & (http://sampo.fmi.fi, last access: 5 April 2018) \\
\hline Aerosol index & L2 & VFD & FMI, KNMI, NASA & (http://sampo.fmi.fi, last access: 5 April 2018) \\
\hline
\end{tabular}

* The aerosol index is currently part of the OMTO3 product, but will transition soon to the OMAERUV product.

\section{Air quality monitoring, air quality forecasting, pollution events, and trends}

OMI collects information on several key pollutants including $\mathrm{NO}_{2}$, aerosols, $\mathrm{SO}_{2}$, and $\mathrm{HCHO}$ (an air toxin), all of which contribute to morbidity and mortality (WHO, 2014), as shown in Fig. 1 where they are averaged over the entire mission. Ozone $\left(\mathrm{O}_{3}\right.$; discussed in Sect. 6) and surface UVB amount are also shown in Fig. 1 for a single day (24 September 2006) when the Antarctic ozone hole reached a record minimum concentration. The amount of $\mathrm{O}_{3}$ and UV exposure are linked and tied to human health, specifically to the risk of vitamin D deficiency and melanoma (Lucas, 2010). Air pollution causes 1 in 9 deaths globally (WHO, 2016), costing the global economy USD 225 billion in lost labor income annually and more than USD 5 trillion in welfare losses (World Bank, 2016). By 2060, 6 to 9 million annual premature deaths are expected with annual global welfare costs projected to rise to USD 18-25 trillion. Ecosystem health is also degraded by air pollution, such as by acid rain, 
eutrophication of water bodies, and oxidation of plant tissue by ozone. Reduced global crop yields are estimated at about $10 \%$ annually (Van Dingenen et al., 2009; Fishman et al., 2010; Avnery et al., 2011), with some heavily polluted areas, like parts of India, experiencing a 50\% reduction (Burney and Ramanathan, 2014).

OMI's spatial coverage is far greater than can be provided by surface monitoring networks. This increases statistical power that strengthens inference of the relation between pollutants and health outcomes. For example, Clark et al. (2014) use $\mathrm{OMI} \mathrm{NO}_{2}$ data to estimate that reducing US nonwhites' exposure to $\mathrm{NO}_{2}$ concentrations to levels experienced by whites would reduce coronary heart disease mortality by about 7000 deaths $\mathrm{yr}^{-1}$. They argue that their results may aid policy-makers in identifying locations with high environmental injustice and inequality. The defining strength of OMI is that it currently provides the finest spatial resolution as compared with previous and present instruments that make measurements in the same spectral range. As an example, Fig. 2 illustrates the comprehensive global coverage of $\mathrm{OMI} \mathrm{NO} 2$ data, but also the unprecedented detail in air pollution changes, down to sub-urban scales (Duncan et al., 2016). Consequently, OMI data are being increasingly exploited for a wide variety of air quality and health applications and in decision making activities (e.g., Streets et al., 2013; Duncan et al., 2014).

Continuing refinements to the OMI retrieval algorithms have resulted in data products that are of sufficient maturity to allow for the reliable and quantitative estimation of concentrations, trends, and fluxes of surface pollutants. However, there are remaining challenges (Martin, 2008; Streets et al., 2013; Duncan et al., 2014; and references therein) that are being addressed. For instance, a fundamental challenge of using these data is the proper "translation" of the observed quantities to more useful surface quantities (Lamsal et al., 2008), such as emissions and concentrations. From the OMI spectra one infers a column density, which is typically reported in units of molecules $\mathrm{cm}^{-2}$. From a column density, one may infer a surface concentration or emission flux if the majority of the temporal variation within the column density is associated with near-surface sources. This is the case for $\mathrm{NO}_{2}, \mathrm{SO}_{2}$, and $\mathrm{HCHO}$ as their chemical lifetimes are short and their primary sources are located near the Earth's surface. As an example, Lamsal et al. (2015) show that the long-term trends and short-term monthly variations in $\mathrm{OMI} \mathrm{NO}_{2}$ column densities from 2005 to 2013 compare well (e.g., $r=0.68$ for trends) with those from the majority of surface concentration observations from the U.S. Environmental Protection Agency's (EPA) Air Quality System (AQS). Lamsal et al. (2015) argue that the spatial coverage afforded by the OMI satellite data in combination with the maturity of the current retrieval algorithm allows for a more representative estimation of $\mathrm{NO}_{2}$ trends within a city than observations from a sparse network of surface monitors. This is the case for many major US cities with typically less than five surface observation monitoring sites. Similar studies are expected to continue in the future with TROPOMI that will provide further improvements in the spatial resolution and per pixel sensitivity.

\subsection{Applications of OMI data for health and air quality studies}

The use of OMI data by the health and air quality communities has grown dramatically within the last few years. For instance, OMI total ozone column data have been used in several studies to understand the impact of UV exposure on human health (e.g., Beckett et al., 2016; Lucock et al., 2016) similar to the earlier TOMS records (e.g., Boscoe and Schymura, 2006; Chang et al., 2010). A consistent long-term global satellite UV radiation time series is useful for several health-related studies (Langston et al., 2017). For HCHO and $\mathrm{NO}_{2}$, the use of the data for health studies has definitely benefited from recent advances in data quality that are the direct result of ongoing OMI retrieval algorithm improvement (Boersma et al., 2011; Bucsela et al., 2013; González Abad, 2015; van Geffen et al., 2015; Marchenko et al., 2015; Krotkov et al., 2017).

\subsection{1 $\mathrm{NO}_{2}$}

OMI $\mathrm{NO}_{2}$ data have been used in a number of recent health studies (e.g., Hystad et al., 2011, 2012; Novotny et al., 2011; Prud'homme et al., 2013; Vienneau et al., 2013; Knibbs et al., 2014; Hoek et al., 2015; Belche et al., 2015; Crouse et al., 2015; de Hoogh et al., 2016; Young et al., 2016). For example, Belche et al. (2013) found that annual OMI $\mathrm{NO}_{2}$ column density data correlate well $(r=0.93)$ with surface data in southern California and provide a reliable measure of spatial variability for $\mathrm{NO}_{2}$ exposure assessment. $\mathrm{NO}_{2}$ has adverse health effects and is correlated with morbidity and mortality (Brook et al., 2007; WHO, 2014), though this correlation may occur because many short-lived air toxins are co-emitted with $\mathrm{NO}_{2}$ and it is a key player in the formation of unhealthy levels of surface ozone (Brook et al., 2007). In fact, Brook et al. (2007) concluded that $\mathrm{NO}_{2}$ is a better indicator than $\mathrm{PM}_{2.5}$ of a range of pollutants (e.g., volatile organic compounds (VOCs), aldehydes, oxidized nitrogen species, and particle-bound organics) from vehicle exhaust. The use of $\mathrm{OMI} \mathrm{NO}_{2}$ data for health studies is attractive given recent advances in the quality of the data that has improved agreement between the data and independent quantities, such as surface $\mathrm{NO}_{2}$ levels and $\mathrm{NO}_{x}$ emissions (e.g., Boersma et al., 2009; Knepp et al., 2013; Lamsal et al., 2015; Duncan et al., 2013, 2016), and improved techniques to infer surface concentrations from satellite data (Lamsal et al., 2008). For example, Ialongo et al. (2016) compared the weekly and seasonal cycle in satellite-based $\mathrm{NO}_{2}$ data and surface concentrations from an air quality station at a high-latitude urban site (i.e., Helsinki, Finland). Despite the challenging view- 

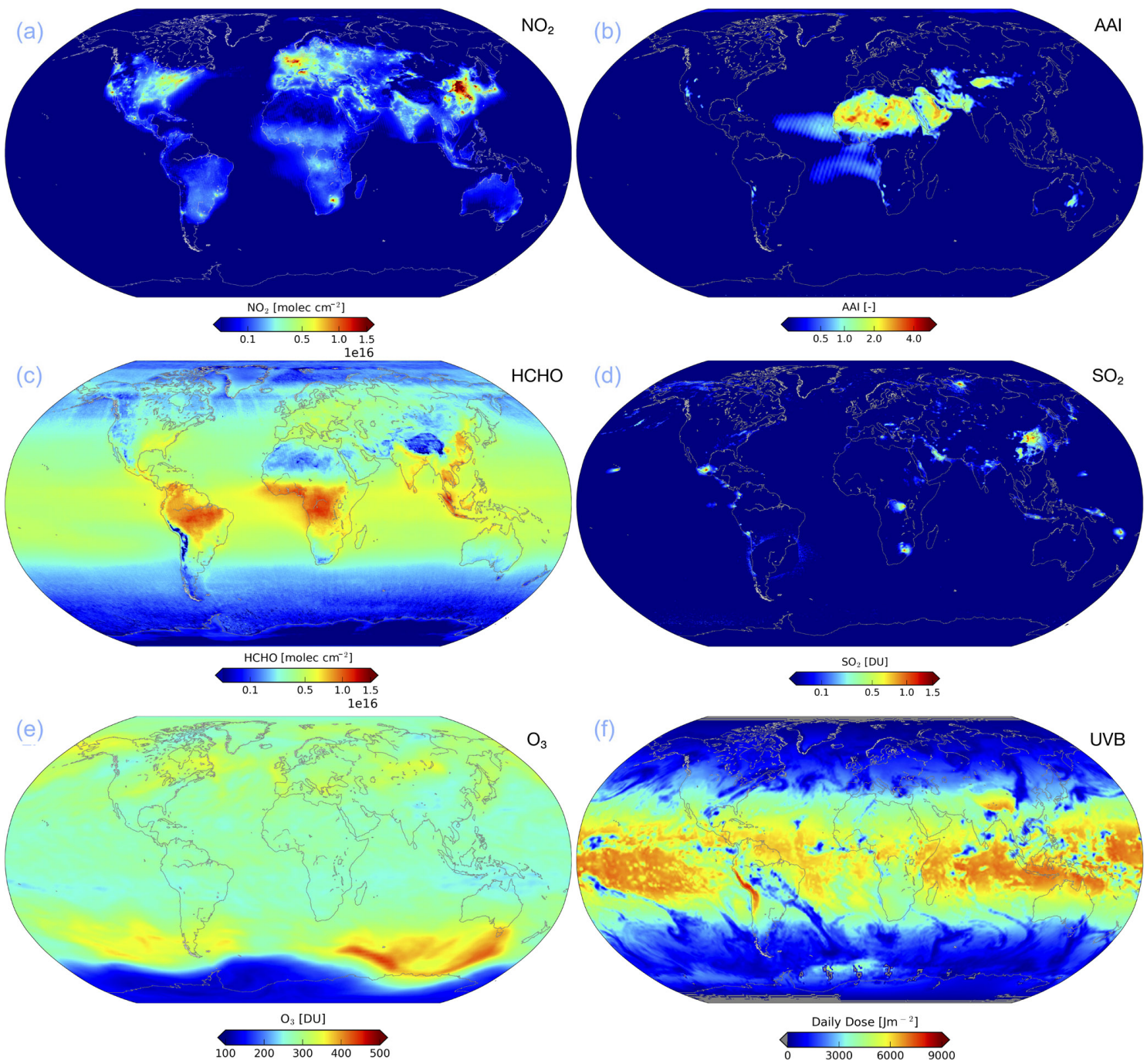

Figure 1. OMI mission averages (2004-2016) for $\mathrm{NO}_{2}$ (a), absorbing aerosol index (AAI; b), HCHO (c), and $\mathrm{SO}_{2}$ (d). Total ozone column $\left(\mathrm{O}_{3} ; \mathbf{e}\right)$ and surface UVB amount (f) are shown for 24 September 2006, the day with a record size ozone hole.

ing conditions and frequent cloud-contamination, $\mathrm{OMI} \mathrm{NO}_{2}$ observations have also shown their capability to describe air quality features at relatively high latitudes.

\subsubsection{HCHO}

$\mathrm{HCHO}$ is an important VOC, acts as an ozone precursor, is associated with the formation of organic aerosols, and is an important carcinogen in outdoor air. It is produced from oxidation of methane and isoprene, and is thus strongly linked to natural emissions. There are also important anthropogenic emissions associated with a range of industrial activities, mostly in the oil- and gas-refining sectors (e.g., Zhu et al., 2014). Trend studies with OMI formaldehyde retrievals indicate increases in $\mathrm{HCHO}$ columns over India and China, and a downward trend over the Amazonian forest, spatially cor- related with areas affected by deforestation (De Smedt et al. 2015)

OMI HCHO data have been used in a number of studies, including to infer health outcomes and to provide top-down constraints on the emissions of VOCs. For example, Zhu et al. (2017) use OMI HCHO data to estimate that 6600-12 200 people in the US will develop cancer over their lifetimes by exposure to outdoor $\mathrm{HCHO}$ derived from biogenic VOC emissions. However, the HCHO yield from VOC oxidation is proportional to $\mathrm{NO}_{x}$ level, so Zhu et al. (2017) note that $\mathrm{NO}_{x}$ emission controls to reduce $\mathrm{O}_{3}$ have the co-benefit of reducing HCHO-related cancer risks. Marais et al. (2012) used $\mathrm{OMI} \mathrm{HCHO}$ data to infer isoprene emissions from Africa and suggested that the MEGAN inventory may significantly overestimate emissions for the region. Millet et al. (2008) found a similar positive bias in MEGAN for North America as compared with OMI retrievals. Zhu et al. (2014) applied an over 


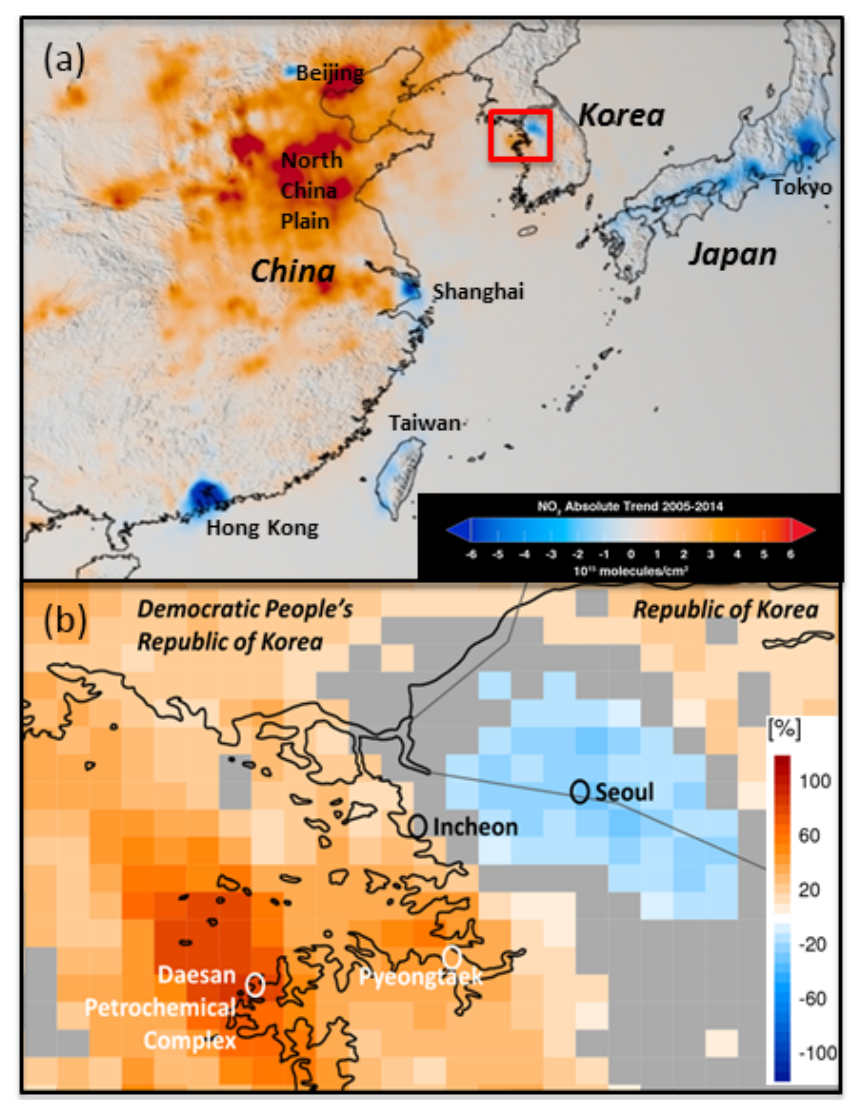

Figure 2. The world shows intriguing spatial heterogeneity and changes in air pollution from 2005 to 2014 in $\mathrm{OMI} \mathrm{NO}_{2}$ (Duncan et al., 2016), a common pollutant from power plants and automobiles. (Top panel) emission controls were implemented before 2010 in Japan, Taiwan, Beijing, Shanghai and Hong Kong, which led to decreasing trends in these regions and cities. Rapid growth until about 2011 in China's manufacturing heartland, the North China Plain, led to increases. Since 2011, levels there have begun to decrease following the gradual introduction of emission controls. The area outlined in red, the Seoul metropolitan area, is expanded in the bottom panel. (Bottom panel) ongoing retrieval algorithm work allows for unprecedented detail, including to sub-urban scales. The Seoul metropolitan area illustrates complex changes in $\mathrm{OMI} \mathrm{NO}_{2}$ from 2005 to 2014, which are likely associated with pollution emission controls in Seoul (decreases) and ambitious infrastructure development (increases) of the Incheon Free Economic Zone, Incheon International Airport, and the Daesan petrochemical complex.

sampling technique to OMI HCHO data, and suggested that anthropogenic emissions of highly reactive VOCs from the Houston area could be several times larger than the EPA estimates. These efforts are currently limited by relatively large uncertainties in satellite retrievals of $\mathrm{HCHO}$, as demonstrated by significant differences in top-down estimates using different sensors (e.g., Barkley et al., 2013). More validation efforts (e.g., Zhu et al., 2016) may help to improve the quality of OMI HCHO data in the future.

\subsection{3 $\mathrm{HCHO}$ and $\mathrm{NO}_{2}$ as $\mathrm{O}_{3}$ precursors}

OMI $\mathrm{NO}_{2}$ and $\mathrm{HCHO}$ data serve as effective proxies for $\mathrm{NO}_{x}\left(\mathrm{NO}+\mathrm{NO}_{2}\right)$ and VOCs, respectively, both necessary ingredients for the formation of unhealthy levels of surface ozone. Martin et al. (2004) demonstrated that the ratio of $\mathrm{HCHO}$ to $\mathrm{NO}_{2}$ column densities can be an effective indicator of ozone's production sensitivity to $\mathrm{NO}_{x}$ and VOC emission reductions. This information is important for the development of effective ozone pollution mitigation strategies. Duncan et al. (2010) used the ratio of OMI HCHO to $\mathrm{NO}_{2}$ columns to show that the chemical sensitivity of ozone formation was becoming more sensitive to $\mathrm{NO}_{x}$ levels in US cities, even cities that were typically considered to be more sensitive to VOCs (e.g., Los Angeles), as a result of substantial reductions in $\mathrm{NO}_{x}$ emissions. Over China, Jin and Holloway (2015) found a complex result owing to significant spatial heterogeneity of $\mathrm{NO}_{x}$ and $\mathrm{VOC}$ emission changes during the OMI record.

\subsection{Improving models and air quality forecasting}

OMI data are being used to improve air quality forecasting in a number of ways. For instance, $\mathrm{OMI} \mathrm{NO}_{2}$ data have been used in several recent studies to identify likely inaccuracies in the chemistry, dynamics, and emissions in air quality models. Travis et al. (2016) used a combination of OMI $\mathrm{NO}_{2}$ data, NASA SEAC ${ }^{4} \mathrm{RS}$ field campaign data, and an atmospheric model to show that industrial and mobile source $\mathrm{NO}_{x}$ emissions in the US EPA National Emission Inventory (NEI) are likely $30-60 \%$ too high. This finding has broad implications for identifying (with air quality models) the most effective and cost-effective strategies to improve AQ. Based on their evidence, Travis et al. (2016) adjusted the NEI NO${ }_{x}$ emissions in their atmospheric model, which reduced part of the high bias in simulated $\mathrm{O}_{3}$. A high bias in simulated $\mathrm{O}_{3}$ relative to observations has been a chronic problem of atmospheric models over the eastern United States. Canty et al. (2015) also used OMI data to diagnose a likely high bias in NEI $\mathrm{NO}_{x}$ emissions, but also in the chemical representation of alky nitrates in a chemical mechanism of an air quality model.

The European Copernicus Atmosphere Monitoring Service (CAMS; https://atmosphere.copernicus.eu/, last access: 4 April 2018) is an operational service providing validated (Eskes et al., 2015) analyses, reanalyses, and daily forecasts of aerosols, reactive gases, and greenhouse gases on a global scale, and air quality forecasts and reanalyses on a regional scale (Marécal et al., 2015). In CAMS, data assimilation techniques are applied to combine in situ and remote sensing observations with global and European-scale models of atmospheric reactive gases, aerosols, and greenhouse gases. The global component is based on the Integrated Forecast System of the ECMWF, and the regional component on an ensemble of seven European air quality models. OMI, and 
in the near future TROPOMI (Veefkind et al., 2012), is providing crucial data for the CAMS assimilation system. OMI data are extensively used in both the global and regional components of CAMS. In the global component, OMI observations of the total ozone column have been assimilated from September 2009 onwards using similar methods as described in Inness et al. (2013), and $\mathrm{OMI} \mathrm{NO}_{2}$ and $\mathrm{SO}_{2}$ are assimilated since July 2012 (Inness et al., 2015). OMI measurements have been used in the last reanalysis (2003-2012 period) produced in the MACC project, the precursor of CAMS (Inness et al., 2013). For the regional air quality service, all seven models have developed data assimilation capabilities for daily air pollution analyses and yearly reanalyses for Europe (Marécal et al., 2015). Here the prime focus is the assimilation of surface observations from the European regulatory network, but several regional models have included OMI $\mathrm{NO}_{2}$.

Figure 3 shows results of the assimilation of OMI $\mathrm{NO}_{2}$ data in the LOTOS-EUROS regional air quality model which is one of the CAMS ensemble members. Within the CAMS ensemble, LOTOS-EUROS is unique because it uses an ensemble Kalman filter approach which adjusts model parameters including the $\mathrm{NO}_{x}$ emissions, while the other models typically use 3D-Var type of approaches which adjust the $\mathrm{NO}_{2}$ concentrations. Figure 3 shows that, despite quite large error bars on the individual $\mathrm{OMI} \mathrm{NO}_{2}$ observations, the model is able to use the data to improve the tropospheric columns. The adjustment of the $\mathrm{NO}_{x}$ emissions significantly influences the chemistry in the boundary layer, and for this assimilation run it was shown that the ozone in the analysis was slightly improved against surface observations in comparison to the run without OMI data. However, the quality and success of such $\mathrm{NO}_{x}$ emission inversions is very sensitive to the quality of the model, the underlying meteorological analyses and to details in the setup of the ensemble Kalman filter. The LOTOS-EUROS model has also been used to study trends of $\mathrm{NO}_{2}$ over Europe (Curier et al., 2014).

A limited number of regional initiatives use OMI satellite products in air quality forecast systems to provide timely information to citizens. Over the US Pacific Northwest, OMI $\mathrm{NO}_{2}$ data have been mostly used to evaluate the air quality forecasting system (Herron-Thorpe et al., 2010). In France, a system was developed that assimilates $\mathrm{OMI} \mathrm{NO}_{2}$ with an optimal-interpolation method in an air quality model to improve $\mathrm{NO}_{2}$ forecasts in Europe (Wang et al., 2011). The assimilation results in an improved capacity of the system to predict $\mathrm{NO}_{2}$ pollution. A similar system was developed by Silver et al. (2013), who showed that the assimilation of OMI tropospheric $\mathrm{NO}_{2}$ columns leads to an improved agreement between predicted and observed surface $\mathrm{NO}_{2}$ concentrations over Europe; they also noted that the effect of assimilation is fairly small and local.

The spatial footprint of OMI aerosol optical depth (AOD) data is broader as compared to data from other instruments, though the OMI products include several important and unique quantities that give important information on aerosol absorption properties of species such as dust and smoke. These OMI data products include near UV (OMAERUV) aerosol record of AOD, single scattering albedo (SSA) and aerosol index (AI; Torres et al., 2007). Retrieved AOD and SSA products have been evaluated using ground-based observations (Ahn et al., 2014; Jethva et al., 2014a) as well as other satellite-based products (Ahn et al., 2008; Gasso and Torres, 2016). OMAERUV observations of aerosol UV absorption spectral dependence are being used to improve tropospheric photochemistry modeling capabilities (X. Wang et al., 2016). As shown by Hammer et al. (2016), when including brown carbon aerosol absorption in the simulation of OMI aerosol observations using an atmospheric model coupled with radiative transfer calculations, the observed discrepancies between simulated and observed hydroxyl radical $(\mathrm{OH})$ concentrations are significantly reduced. The inclusion of brown carbon aerosol decreases $\mathrm{OH}$ by up to $35 \%$ over South America in September, up to $25 \%$ over southern Africa in July, and up to $20 \%$ over other biomass burning regions. Modeled global annual mean $\mathrm{OH}$ concentrations decrease due to the presence of absorbing brown carbon aerosol, thus reducing the bias against observed values.

\subsection{Trends in pollutants and aerosol presence}

This section highlights the use of the long OMI data record for better understanding trends in pollutants including $\mathrm{SO}_{2}$ and $\mathrm{NO}_{2}$ particularly in China (e.g., Wang et al., 2012; Ling et al., 2017; Liu et al., 2016a, 2017; Zhang et al., 2017) and India (David and Nair, 2013; Ghosh et al., 2017), as well as for aerosol presence using the OMI aerosol index. OMI's data have been used to infer substantial trends that have occurred in $\mathrm{SO}_{2}$ and $\mathrm{NO}_{2}$ pollution around the world over the last decade (e.g., Duncan et al., 2016; Krotkov et al., 2016). These changes are largely consistent with the implementation of environmental regulations on emissions and changes in economic output, including changes resulting from the global economic recession of 2008-2009 (e.g., Castellanos and Boersma, 2012; Russell et al., 2012; Boersma et al., 2015; Duncan et al., 2016; Krotkov et al., 2016; de Foy et al., 2016a). For example, Fioletov et al. (2011), Zhou et al. (2012), and Duncan et al. (2013) used OMI SO 2 and $\mathrm{NO}_{2}$ column density data to quantify the substantial reductions in pollution over US and Spanish power plants, which primarily resulted from the implementation of emission control devices. They showed that the changes in the OMI column densities agree well with changes in power plant emissions reported to the US EPA Continuous Emissions Monitoring System (CEMS). Over urban areas, de Foy et al. (2016a) used OMI $\mathrm{NO}_{2}$ columns to show that there were regional differences in the impact of the recession as well as in the strength of the weekend effect.

Over the eastern US, both $\mathrm{NO}_{2}$ and $\mathrm{SO}_{2}$ levels decreased dramatically from 2005 to 2015 , by more than 40 and $80 \%$, 


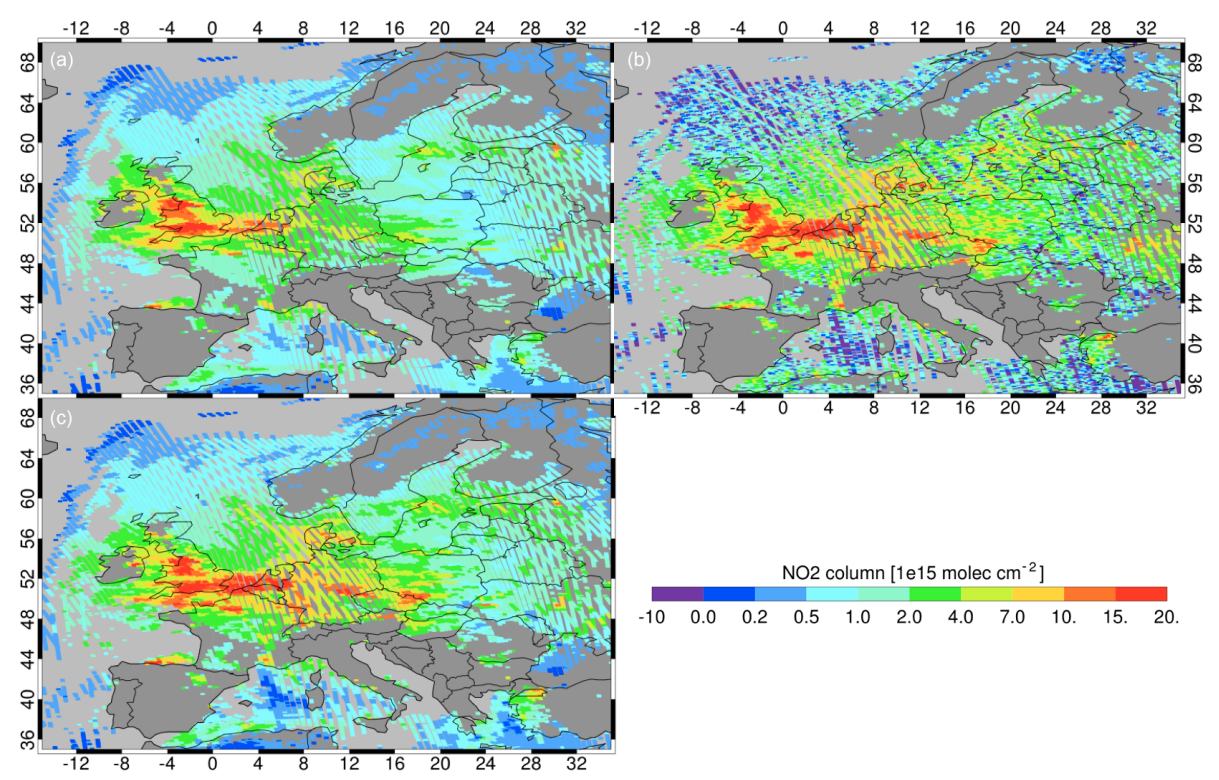

Figure 3. Example result of the assimilation of $\mathrm{OMI} \mathrm{NO}_{2}$ tropospheric column amounts (DOMINO-2 product, b) on 26 March 2007 in the LOTOS-EUROS regional air quality model (model simulation for OMI ground pixels is provided in a by spatial interpolation and by applying the averaging kernels). LOTOS-EUROS makes use of the ensemble Kalman filter to optimize model processes by assimilating observations. In this case, the surface $\mathrm{NO}_{x}$ emissions are adjusted to optimize the match with the tropospheric $\mathrm{NO}_{2}$ columns observed. The resulting analysis is shown in (c). OMI observations for cloud-covered scenes (cloud radiance fraction $>50 \%$ ) are removed.

respectively, as a result of both technological improvements and stricter regulations of emissions. Similarly, OMI confirmed large reductions in $\mathrm{SO}_{2}$ over eastern Europe's largest coal-fired power plants after installation of flue gas desulfurization devices. In stark contrast to decreasing surface pollution in the US and Europe, the booming Chinese and Indian economies and limited environmental regulation of emissions led to large increases in $\mathrm{NO}_{2}$ and $\mathrm{SO}_{2}$ levels indicated by OMI (e.g., Wang et al., 2012; Li et al., 2010; Lin and McElroy, 2011; Lu and Streets, 2012; Verstraeten et al., 2015). The North China Plain, China's manufacturing heartland, has the world's most severe $\mathrm{SO}_{2}$ pollution, but a decreasing trend has been observed since 2011 due to an economic slowdown and government efforts to restrain emissions from the power and industrial sectors thus leading to improvements in air quality (e.g., Krotkov et al., 2015; van der A et al., 2017; de Foy et al., 2016b; Wang et al., 2015). In contrast, India's $\mathrm{SO}_{2}$ and $\mathrm{NO}_{2}$ levels from coal power plants and smelters are growing at a fast pace, increasing by more than 100 and $50 \%$, respectively, from 2005 to 2015. In a recent study, Li et al. (2017a) showed that India is surpassing China as the world's largest emitter of anthropogenic $\mathrm{SO}_{2}$. Boersma et al. (2015) used OMI $\mathrm{NO}_{2}$ observations to derive the changes in polluting emissions from European shipping.

OMI data can also be used in combination with other satellite data sets to establish even longer data records useful for trend analysis, as has been carried out using aerosol data products (Popp et al., 2016; Dahutia et al., 2017) and total ozone column (see Sect. 6.1). As can be seen in Fig. 4, the aerosol index covers a period of nearly 40 years and brings together data from both the European and American communities (Nimbus-7 TOMS, GOME, SCIAMACHY, OMI, GOME-2A, and GOME-2B). This data record can be used to better understand regional and global trends in the presence of UV-absorbing aerosols including desert dust and biomass burning aerosols.

\section{Top-down emissions estimates}

OMI data have played a key role in the top-down estimation of $\mathrm{NO}_{x}, \mathrm{SO}_{2}$, and VOC emissions. Particulate matter (PM) emissions may be inferred via OMI AOD measurements, but a direct relationship with PM emissions is still elusive (e.g., Hoff and Christopher, 2009). Because statistical data needed by bottom-up inventories often take years to collect, the short-term availability of satellite data is often used to show the latest trends in emissions and the effectiveness of air quality regulations (e.g., de Foy et al., 2016a; Duncan et al., 2016; Krotkov et al., 2016; Liu et al., 2018). OMI observations allow the emission sources to be resolved at a higher resolution than before, which is a distinct advantage for point sources of short-lived gases, including $\mathrm{NO}_{2}$ and $\mathrm{SO}_{2}$, since their sources can be derived with relatively simple methods based on mass balance (e.g., Duncan et al., 2013; de Foy et al., 2015; Fioletov et al., 2015, 2016; Liu et al., 2016a; McLinden et al., 2016a). Complete emission maps from OMI observations have been derived using full inversion methods that involves the use of chemical trans- 

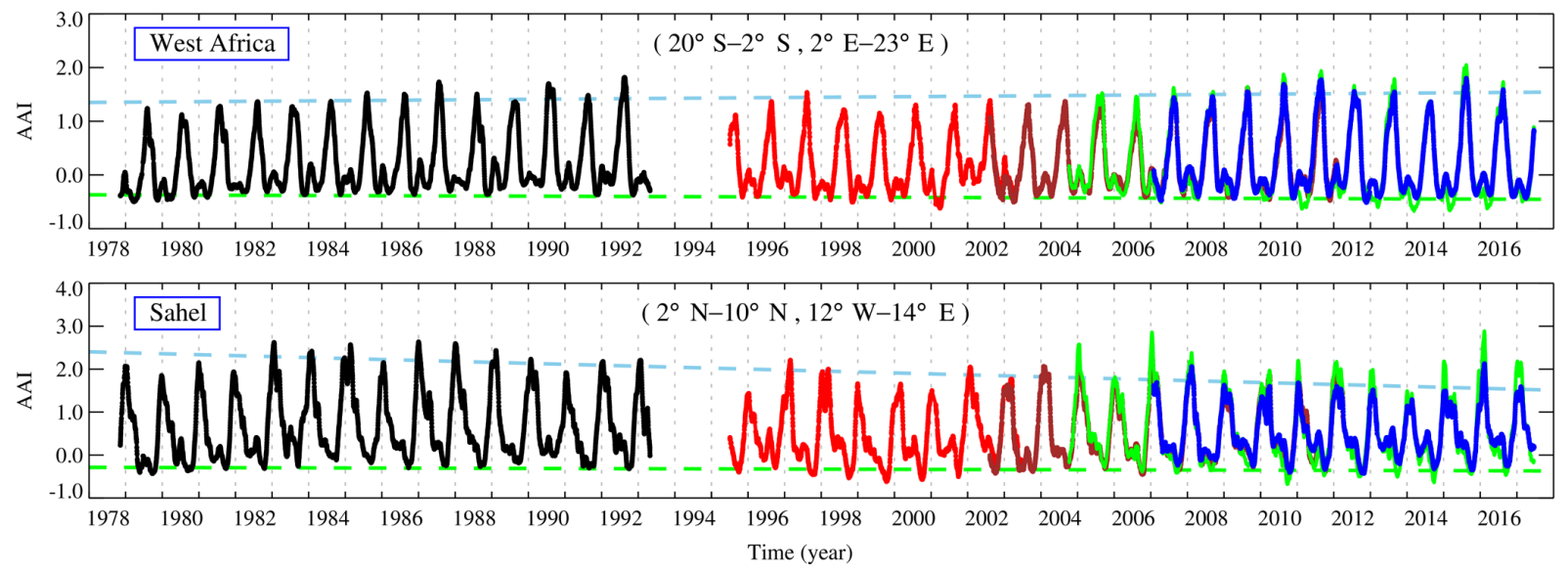

Figure 4. Time series of regional mean absorbing aerosol index (AAI) for two aerosol regions. The time series consists of data from TOMS (black), GOME (red), SCIAMACHY (brown), OMI (light green), and GOME-2 (blue). The latitude and longitude ranges that define the regions are provided in the plot windows. The dashed green lines indicate linear fits to the yearly minima of the time series, and illustrate the stability of the data records. The dashed blue lines represent linear fits to the yearly maxima of the time series. These describe trends in aerosol presence for the regions over the entire time range covered by the time series.

port models (Qu et al., 2017). Streets et al. (2013) reviewed the current capability to estimate emissions from space, and in this section we highlight studies of emissions using OMI data that have been published subsequently. We expect that such efforts will be continued with the higher spatial resolution afforded by the S5P TROPOMI that has the ability to detect even smaller sources per pixel than is currently possible with OMI.

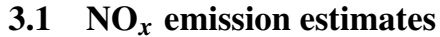

The top-down estimation of $\mathrm{NO}_{x}$ emission sources is especially successful because of the strength of the OMI signal and therefore its potential to detect low-intensity sources. Applications have included the detection of signal from ship emissions (Vinken et al., 2014a), the Canadian oil sands (McLinden et al., 2014), soil emissions (Vinken et al., 2014b), biomass burning (Castellanos et al., 2014), and from urban and industrial areas (Lin, 2012; Vienneau et al., 2013; Ghude et al., 2013; Liu et al., 2018). Another recent development has been the application of $\mathrm{OMI} \mathrm{NO}_{2}$ data to studies of nitrogen deposition flux (Nowlan et al., 2014; Han et al., 2017). Trend studies of $\mathrm{NO}_{x}$ point sources were performed by, for example, de Foy et al. (2015) who derived $\mathrm{NO}_{x}$ emissions from 29 isolated power plants in the US. $\mathrm{Lu}$ et al. (2015) estimated summertime $\mathrm{NO}_{2}$ emissions from 35 US urban areas. A slightly different method was used by Liu et al. (2016b) to estimate emissions and lifetimes for 17 power plants and 53 cities located in non-mountainous regions across China and the USA.

Full inversion emission estimates for $\mathrm{NO}_{x}$ from OMI observations using a chemical transport model (CTM) continue to be improved by various research groups. Stavrakou et al. (2013) applied a 4DVAR inversion on OMI $\mathrm{NO}_{2}$ ob- servation using a global CTM. Miyazaki et al. (2012) and Miyazaki and Eskes (2013) applied an ensemble Kalman filter scheme on observations of multiple species retrieved with OMI. Mijling and van der A (2012) further developed their Daily Emission estimates Constrained by Satellite Observations (DECSO) algorithm for high-resolution regional emission estimates using an extended Kalman filter. DECSO has been applied for Europe, eastern China, India, South Africa, and the Middle East.

Figure 5 shows $\mathrm{NO}_{x}$ emissions in the Middle East based on the latest bottom-up inventory, the Emission Database for Global Atmospheric Research (EDGAR) v4.3 and the DECSO algorithm version $3 \mathrm{~b}$. Because of the fast availability of satellite-derived emissions, the DECSO results show the change of ship routes along the coast of Somalia as a result of the increased number of piracy cases. Notably in the DECSO emission map is the dispersion of ships east of Yemen and the more realistic stronger economic activity in the Persian Gulf region. With the improved DECSO algorithm version 5 even ship tracks hidden under the strong outflow of pollution along the Chinese coast became clearly visible (Ding et al., 2017a). The possibilities of high-resolution emissions are demonstrated by Ding et al. (2015) who showed the temporal effect of air quality regulations on city emissions during the Youth Olympic Games in Nanjing. Trends in these $\mathrm{NO}_{x}$ emissions based on 12 years of OMI observations have been analyzed by Mijling et al. (2013) for China, by van der A et al. (2017) for China including the relation with air quality regulations, and by Miyazaki et al. (2017) on a global scale. Emission inventories over China were validated by a detailed intercomparison of five bottom-up inventories and four satellite-derived emission inventories using GOME-2 and OMI (Ding et al., 2017b). 

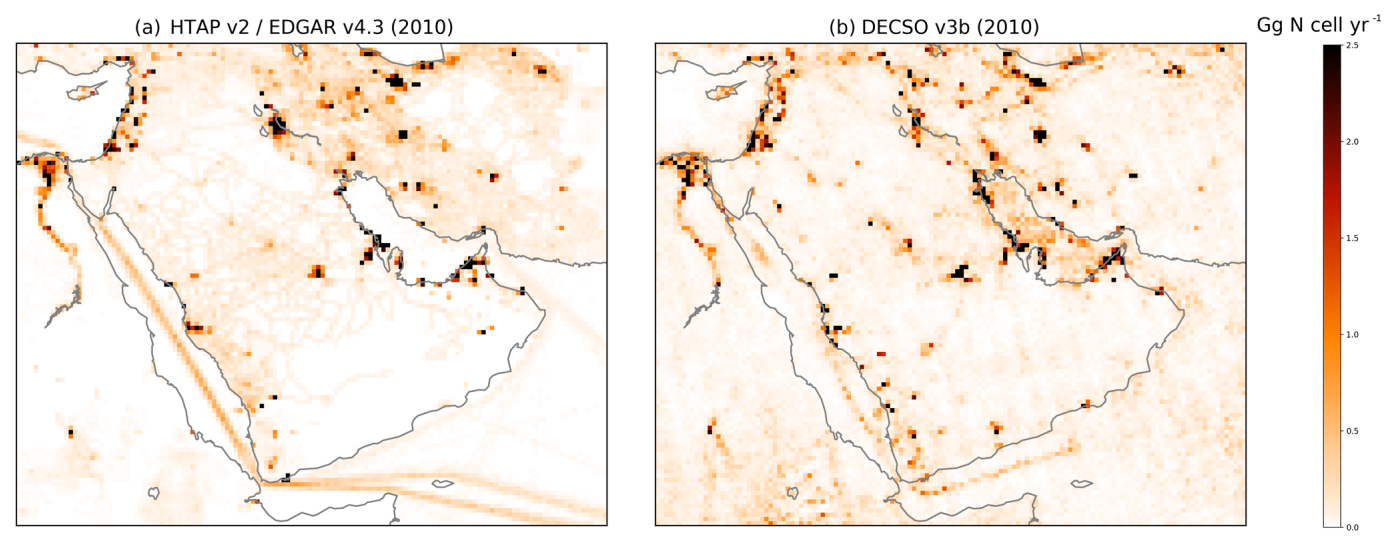

Figure 5. $\mathrm{NO}_{x}$ emissions in the Middle East in 2010 derived from (a) the bottom-up inventory EDGAR v4.3 and (b) the DECSO algorithm v3b applied to $\mathrm{OMI} \mathrm{NO}_{2}$ observations.

\section{2 $\mathrm{SO}_{2}$ emission estimates}

Though the $\mathrm{SO}_{2}$ signal from OMI is 2 to 3 orders of magnitude weaker than the $\mathrm{NO}_{2}$ signal, oversampling ${ }^{2}$ and other data enhancement techniques have enabled valuable new studies of $\mathrm{SO}_{2}$ emissions from refineries and volcanoes (de Foy et al., 2009) and the Canadian oil sands (McLinden et al., 2014). Also, using specific sampling techniques, OMI observations were used as the first satellite observation of $\mathrm{SO}_{2}$ ship track emissions (Theys et al., 2015). Fioletov et al. (2013) reviewed the ability of OMI to detect large $\mathrm{SO}_{2}$ sources worldwide, including power plants, oil fields, metal smelters, and volcanoes. Work continues on the challenge of developing reliable quantitative relationships between OMI observations and emissions for large isolated sources. Previous work had only moderate success in correlating observations with emissions.

An alternative approach, well-suited for deriving emissions from continuously emitting (near-) point sources that does not require the use of atmospheric chemistry models, is based on merging OMI measurements of tropospheric columns with wind information and examining the downwind decay of the pollutants (Beirle et al., 2011). This approach spawned several studies on $\mathrm{SO}_{2}$ emissions (Fioletov et al., 2011, 2015; de Foy et al., 2015; Lu et al., 2013, 2015; Wang et al., 2015) utilizing increasingly complex analysis methods in which an estimate of the total mass near the source and its lifetime or, more accurately, decay time were derived. Assuming a steady state, the emission strength can be obtained from the ratio between mass and decay time. The mass can be derived directly from satellite measurements, while the lifetime can either be prescribed using known emissions (Fioletov et al., 2013, 2016) or estimated from the mea-

\footnotetext{
${ }^{2}$ The fact that daily pixels do not match spatially can be used to sample data to a grid that is smaller than the pixel size. This is called oversampling. Oversampling was first applied to OMI data by de Foy et al. (2009) and Russell et al. (2010).
}

surements based on the rate of decay of vertical column density (VCD) with distance downwind (Beirle et al., 2014; Carn et al., 2013; de Foy et al., 2015).

OMI $\mathrm{SO}_{2}$ data, significantly improved with a principal component analysis algorithm (Li et al., 2013), was combined with a new emission-source detection algorithm (Fioletov et al., 2015) to compile the first global, satellite-based emissions inventory of point $\mathrm{SO}_{2}$ emission sources (Fioletov et al., 2016). The inventory contains estimates of annual emissions for 491 medium to large sources (volcanoes, power plants, oil- and gas-related sources, and smelters) that emit from $30 \mathrm{kt} \mathrm{yr}^{-1}$ and is completely independent of conventional information sources. It was used for verification of traditional "bottom-up" $\mathrm{SO}_{2}$ emission inventories and identification of missing sources. Nearly 40 of the sources identified by this new method were found to be missing from leading emission inventories, representing about $12 \%$ of the global total (McLinden et al., 2016b). Regionally, emissions can be off by factors of 2 or 3. Many of the missing $\mathrm{SO}_{2}$ sources were located in the Middle East and related to the oil and gas sector (Fig. 6). OMI is also able to capture annual variability of $\mathrm{SO}_{2}$ emissions for all detected sources of magnitude 30-4000 $\mathrm{kt} \mathrm{yr}^{-1}$ when averaged over 2005-2015 (Fioletov et al., 2016).

\subsection{VOC emission estimates}

OMI detects the small organic molecules formaldehyde and glyoxal. OMI formaldehyde data have been used to infer natural emissions of isoprene, a key contributor to $\mathrm{O}_{3}$ production in many parts of the world and the largest VOC source globally (e.g., Millet et al., 2008; Duncan et al., 2009, 2010; Curci et al., 2010; Marais et al., 2012, 2014; Barkley et al., 2013; Zhu et al., 2014; Stavrakou et al., 2015; Bauwens et al., 2016). More recently, Valin et al. (2016) investigated the influence of the hydroxyl radical $(\mathrm{OH})$ and VOC variability on the OMI HCHO column, which is important when inferring fluxes of VOCs using OMI HCHO columns. They 


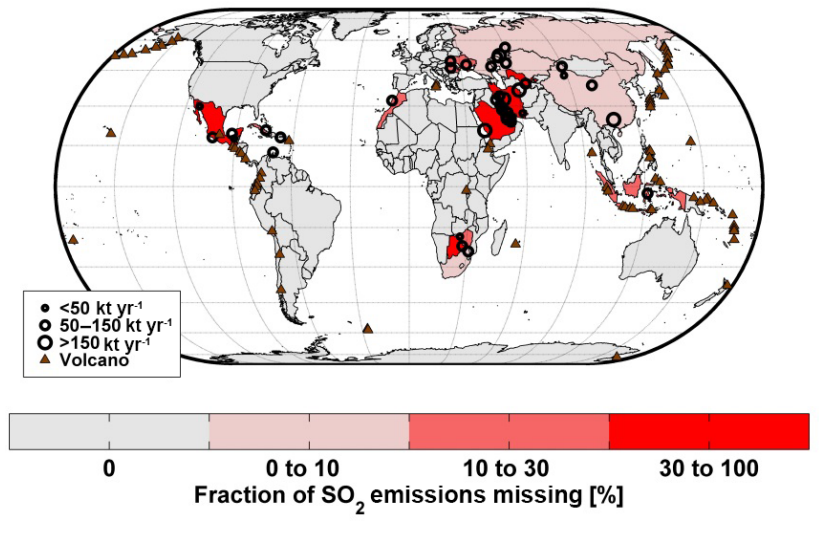

Figure 6. Point sources of $\mathrm{SO}_{2}$ identified that were found to be missing from three leading bottom-up inventories (from McLinden et al., 2016b). Each nation is color-coded according to its total fraction of $\mathrm{SO}_{2}$ emissions that are missing, relative to its total national emissions (the sum of Hemispheric Transport of Air Pollution, HTAP, emissions and missing sources).

conclude that the column primarily depends on $\mathrm{OH}$ production rates $(\mathrm{POH})$ at low $\mathrm{OH}$ concentrations, on both $\mathrm{POH}$ and VOC reactivity (VOCR) at moderate $\mathrm{OH}$, and on VOCR at high $\mathrm{OH}$. OMI observations have also been used to estimate anthropogenic emissions of highly reactive VOCs over the southeast US (Zhu et al., 2014). VOC emissions derived from OMI HCHO observations showed that crop burning in the North China Plain was underestimated by a factor of 2 in traditional emission inventories (Stavrakou et al., 2016). The combination of OMI HCHO and OMI glyoxal measurements (see Sect. 8.3) can provide useful information on VOC speciation (DiGangi et al., 2012; Chan Miller et al., 2016) and can constrain VOC emissions (Stavrakou et al., 2009).

\section{4 $\mathrm{NO}_{2}$ as indicator for anthropogenic $\mathrm{CO}_{2}$ emissions}

OMI observations are being synergistically combined with observations from other satellite instruments to provide information, such as the quantification of emissions, inference of co-emitted trace gases, and the identification of source regions and types, that neither instrument could do alone. These recent developments in the combined interpretation of $\mathrm{NO}_{2}$ and carbon dioxide $\left(\mathrm{CO}_{2}\right)$ satellite emissions have gained much scientific attention. Duncan et al. (2016) showed that $\mathrm{OMI} \mathrm{NO}_{2}$ can differentiate individual power plant sources even in complex source regions and proposed that $\mathrm{NO}_{2}$ may be used to infer $\mathrm{CO}_{2}$ emissions assuming a characteristic $\mathrm{CO}_{2}: \mathrm{NO}_{2}$ emission ratio. Hakkarainen et al. (2016) show that $\mathrm{OMI} \mathrm{NO}_{2}$, an indicator of atmospheric pollution, may be used to aid in the interpretation of the NASA Orbiting Carbon Observatory-2 (OCO-2) carbon dioxide data (see also Eldering et al., 2017). The spatial distribution of OMI tropospheric $\mathrm{NO}_{2}$ matched the features observed in the maps of OCO-2 $\mathrm{CO}_{2}$ anomalies over the main polluted regions. Furthermore, the results of a cluster analysis between $\mathrm{OMI} \mathrm{NO}$ and OCO-2 $\mathrm{CO}_{2}$ confirmed the spatial correlation over areas with different amounts of pollution. Konovalov et al. (2016) found that $\mathrm{OMI} \mathrm{NO}_{2}$ data can provide a better constraint than IASI CO data for anthropogenic $\mathrm{CO}_{2}$ emissions. This is important as inferring emissions with current satellite $\mathrm{CO}_{2}$ data sets (e.g., OCO-2, GOSAT) is challenging for a variety of reasons.

\section{Volcanic monitoring with OMI}

OMI can lay claim to being the first satellite instrument to be used for daily monitoring of volcanic emissions (e.g., Carn et al., 2008, 2013; McCormick et al., 2013; Flower and Carn, 2015), heralding a new era where satellite measurements have become an indispensable tool for volcanic gas monitoring in many regions. While instruments such as TOMS have been measuring $\mathrm{SO}_{2}$ and ash emissions by major eruptions since 1978 (e.g., Krueger, 1983; Carn et al., 2016), and GOME first demonstrated the potential for detection of tropospheric volcanic $\mathrm{SO}_{2}$ from space by hyperspectral UV sensors (Eisinger and Burrows, 1998), the "volcano-scale" pixel size $\left(13 \times 24 \mathrm{~km}^{2}\right.$ at nadir $)$ of OMI was a critical factor. OMI's ability to detect volcanic $\mathrm{SO}_{2}$ at all levels from the planetary boundary layer (PBL) to the stratosphere, derived from volcanic activity of varying intensity from passive degassing to major stratospheric eruptions, has required the development of $\mathrm{SO}_{2}$ retrieval algorithms capable of spanning several orders of magnitude of $\mathrm{SO}_{2}$ column amount (e.g., from 0.2-2000 Dobson units (DU); Krotkov et al., 2006; Yang et al., 2007, 2009b, 2010; Li et al., 2013, 2017b; Theys et al., 2014) and direct retrieval of $\mathrm{SO}_{2}$ altitude from UV radiances (e.g., Yang et al., 2009a, 2010).

Unlike the 1978 to 2005 period of TOMS measurements, which featured the major $\mathrm{SO}_{2}$-rich eruptions of El Chichón (Mexico) in 1982 (Krueger, 1983) and Pinatubo (Philippines) in 1991 (Bluth et al., 1992), the decade since the OMI launch has seen no eruptions of comparable magnitude (Carn et al., 2016). The largest tropical eruption occurred at Nabro (Eritrea) in June 2011, but was an order of magnitude smaller than Pinatubo (Goitom et al., 2015). Nevertheless, the OMI era has been notable for a number of large, highlatitude eruptions (e.g., 2008 Okmok, 2008 Kasatochi, 2009 Sarychev Peak, 2009 Redoubt, 2014 Holuhraun), with the eruption of Kasatochi (Aleutian Islands, US) in August 2008 representing one of the largest stratospheric $\mathrm{SO}_{2}$ injections of the last decade (e.g., Krotkov et al., 2010; Wang et al., 2013). Although none of these eruptions were large enough to impact climate (due to the high latitude and insufficient $\mathrm{SO}_{2}$ release), they have presented several opportunities for OMI $\mathrm{SO}_{2}$ validation, owing to the limited latitudinal spread of the volcanic clouds and the abundance of ground stations at midto high-latitudes (e.g., Spinei et al., 2010; Carn and Lopez, 2011; Lopez et al., 2013; Ialongo et al., 2015). Operation 
of Aura in the A-train constellation has facilitated validation by providing critical observations of volcanic cloud altitude (e.g., from the Cloud-Aerosol Lidar and Infrared Pathfinder Satellite Observation, CALIPSO; Spinei et al., 2010; Carn and Lopez, 2011).

Despite the lack of major, climate-forcing eruptions, the OMI era has been far from volcanically quiescent (e.g., Prata et al., 2010; Carn and Prata, 2010; Carn et al., 2016). The absence of significant volcanic perturbations to stratospheric AOD in the post-Pinatubo period to date has focused attention on the impacts of smaller, more frequent volcanic eruptions on "background" stratospheric AOD and related subtle climate impacts (e.g., Solomon et al., 2011; Vernier et al., 2011; Santer et al., 2014). Although the implication of increased rates of volcanic activity in 2000-2010 in a putative "global warming hiatus" is now deemed unlikely, accurate $\mathrm{OMI}$ and A-train observations of volcanic $\mathrm{SO}_{2}$ loading and altitude for all significant volcanic eruptions (e.g., Carn, 2015; Carn et al., 2016) continue to play a crucial role in unraveling the major natural sources of stratospheric AOD variability. OMI observations of reactive halogens (e.g., $\mathrm{BrO}$, OClO) in volcanic eruption clouds (e.g., Theys et al., 2014) also permit improved understanding of volcanic impacts on stratospheric ozone.

Since the first demonstration of OMI's ability to quantify volcanic $\mathrm{SO}_{2}$ degassing (Carn et al., 2007b, 2008), an important indicator of impending eruptions, OMI observations have been adopted by many volcano observatories worldwide as an essential tool for volcano surveillance. OMI data have subsequently been used to investigate or monitor volcanoes in most volcanic regions of the globe, including east Africa (e.g., Sawyer et al., 2008; Ferguson et al., 2010; Goitom et al., 2015), Indonesia (Surono et al., 2012; Kushendratno et al., 2012), Papua New Guinea (McCormick et al., 2012), Vanuatu (Bani et al., 2009a, b, 2012), Central America (Campion et al., 2012), the West Indies (Carn and Prata, 2010; Flower and Carn, 2015), Ecuador (Carn et al., 2008), Chile (Theys et al., 2014), Russia (Telling et al., 2015), Alaska, US (Lopez et al., 2013), and Iceland (Sigmarsson et al., 2013; Schmidt et al., 2015). Satellite measurements of elevated $\mathrm{SO}_{2}$ emissions (including from $\mathrm{OMI}$ ) were decisive in providing advance warning of a major eruption at Merapi (Indonesia) in 2010, permitting evacuation of the flanks of the volcano and saving many lives (Surono et al., 2012).

Recent improvements in $\mathrm{SO}_{2}$ algorithm sensitivity (Li et al., 2013, 2017b; Theys et al., 2015) have increased the sensitivity of OMI measurements to weak volcanic $\mathrm{SO}_{2}$ degassing. Coupled with new $\mathrm{SO}_{2}$ emission estimation techniques (Fioletov et al., 2011), these data have permitted the identification of $\sim 100$ volcanic $\mathrm{SO}_{2}$ emission sources (roughly two-thirds of the $\sim 150$ degassing volcanoes known worldwide), including some sources in remote regions with no prior measurements, which will comprise a new volcanic $\mathrm{SO}_{2}$ emissions inventory (Fioletov et al., 2016; Carn et al., 2017). This inventory will improve constraints on volcanic emissions of other important gases, such as $\mathrm{CO}_{2}$, which are difficult to measure directly.

A significant increase in demand for NRT satellite observations of volcanic clouds occurred following the Eyjafjallajökull eruption in Iceland in April-May 2010, which disrupted aviation operations on a global scale. UV measurements have some unique advantages for volcanic ash detection, notably the ability to detect ash (and $\left.\mathrm{SO}_{2}\right)$ when located above or mixed with clouds (e.g., Carn et al., 2009; Carn and Krotkov, 2016). Timeliness of observations and data delivery is critical for aviation safety, and this has been optimized by using satellite direct broadcast/readout (DR) capabilities. The operational OMI VFD service (Hassinen et al., 2008) for NRT detection of volcanic $\mathrm{SO}_{2}$ and ash emissions was implemented at FMI in 2011. The existing SAMPO service (http://sampo.fmi.fi/volcanic.html, last access: 5 April 2018) utilizes the DR capability of the Aura/OMI and SNPP/OMPS instruments and the ozone, cloud reflectivity, volcanic $\mathrm{SO}_{2}$ and aerosol index (AI) products are available to users, including the Support to Aviation Control Service (SACS; http: //sacs.aeronomie.be/nrt, last access: 5 April 2018; Brenot et al., 2014) and Volcanic Ash Advisory Centers (VAACs), within $20 \mathrm{~min}$ after the satellite overpass over a ground station.

The two ground stations, one in Sodankylä (northern Finland, used for both OMI and OMPS) and the second in Fairbanks (Alaska, US, used for OMPS), ensure spatial coverage over busy airspace in the north Atlantic and north $\mathrm{Pa}$ cific with many active volcanoes. The ongoing NASA Applied Sciences Project will enhance the decision support system services and tools used at VAACs by combining realtime satellite DR observations with volcanic cloud dispersion modeling to provide improved forecasts of the $\mathrm{SO}_{2}$ and ash together with the observations.

The Sodankylä VFD system proved its usefulness during two recent Icelandic eruptions: Grimsvötn in 2011 (Kerminen et al., 2011) and Holouraun-Bárðarbunga in 2014-2015 (Ialongo et al., 2015) as shown in Fig. 7. These recent eruptions also demonstrated that, in addition to aviation hazard mitigation, the OMI DR data could be used to anticipate and monitor air quality impacts due to low-altitude volcanic $\mathrm{SO}_{2}$ and ash clouds.

\section{Solar spectral irradiance monitoring}

OMI collects solar spectral irradiance (SSI) data primarily to provide long-term on-orbit calibration, in particular for characterization of throughput degradation and wavelength calibration. These goals have been met very well, as described in detail by Schenkeveld et al. (2017). Most OMI level 2 products use a constant solar irradiance reference spectrum to produce Earth reflectance data that are used in the actual retrieval processing. This "fixed" irradiance spectrum comes from either an external high-resolution composite data set 

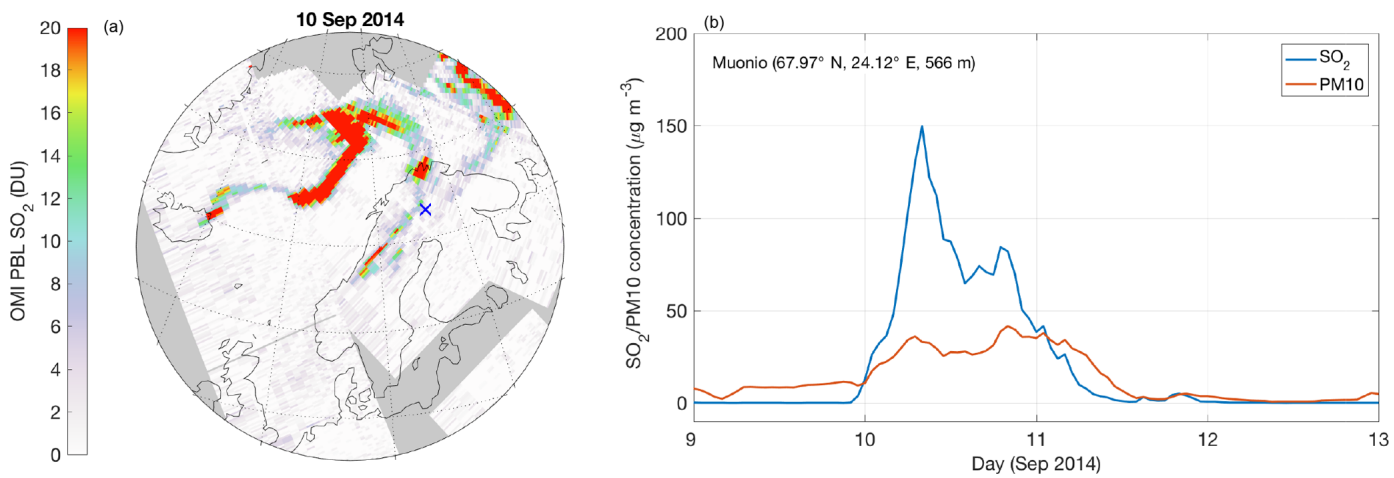

Figure 7. (a) Detection of $\mathrm{SO}_{2}$ emissions from the Holuhraun (Iceland) eruption by the OMI very fast delivery (VFD) system on 10 September 2014. (b) Ground-based $\mathrm{SO}_{2}$ measurements and breathable aerosols $\left(\mathrm{PM}_{10}\right)$ over Muonio measurement station (Finland; location indicated by a cross on the VFD image) from 9 September up until and 13 September 2014.

(e.g., Dobber et al., 2008a) or from the early epoch (20042005) OMI irradiance measurements. However, numerous observations show substantial solar variability (up to $\sim 2 \%$ in strong spectral lines at the OMI spectral resolution, and larger for higher-resolution measurements; see Fig. 8) for the spectral region below $300 \mathrm{~nm}$ on both solar rotational ( $\sim 27$ day) and solar cycle ( 11-year) timescales (e.g., DeLand and Cebula, 2008). Similar variations are also clearly seen in the cores of selected Fraunhofer lines longward of $300 \mathrm{~nm}$ (Fig. 8). More importantly, results from the SIM (Spectral Irradiance Monitor) instrument on the SORCE (Solar Radiation and Climate Experiment) satellite (Harder et al., 2009) and their implications for climate response (Haigh et al., 2010) have led to ongoing debate regarding the magnitude of solar cycle variability across the entire OMI spectral region (e.g., DeLand and Cebula, 2012; Lean and DeLand, 2012; Ermolli et al., 2013; Morrill et al., 2014; Ball et al., 2016). Thus, developing an independent SSI data set from OMI has significant potential benefits for both solar physics and climate studies.

Creating a SSI data set from OMI measurements requires a comprehensive correction for instrument response degradation, which can have a complex spectral and temporal dependence (e.g., Floyd et al., 1998; DeLand and Cebula, 2008). A first step in this process is to demonstrate that OMI fully captures solar activity variations by creating a proxy index that is insensitive to most instrument degradation effects. This can be done using core-to-wing ratios for absorption features such as Mg II $h$ and $k(280 \mathrm{~nm})$, Ca II K $(393.4 \mathrm{~nm})$, and Ca II H (396.8 nm). DeLand and Marchenko (2013) describe the creation of $\mathrm{Mg}$ II index and Ca II index products from OMI irradiance data and show that these products agree very well with concurrent solar activity data sets from GOME, SORCE SOLSTICE (Solar-Stellar Irradiance Comparison Experiment), and the US National Solar Observatory.

Since OMI does not carry an end-to-end onboard calibration system, some form of external information is necessary to develop a long-term degradation correction. Marchenko and DeLand (2014) and Marchenko et al. (2016) created accurate $(\sim 0.1-0.3 \%$ per $0.5-1.0 \mathrm{~nm}$ spectral bin; available on-line at https://sbuv2.gsfc.nasa.gov/solar/omi/, last access: 5 April 2018) degradation corrected daily OMI irradiance data. These data serve as a valuable, independent source for detailed comparisons with both SORCE measurements and widely used solar spectral irradiance models, thus providing important constraints on solar variability in the near-UV and visible regions. Continuation of these solar irradiance measurements by TROPOMI will be a valuable contribution in the coming years.

\section{The Montreal Protocol, total ozone, and UV radiation}

In 1987, the Montreal Protocol was established in an effort to protect the ozone layer. Ozone measurements by satellite are an important means to assess the Montreal Protocol's effectiveness to enable the ozone layer recovery from the effects of ozone depleting substances. NASA's contribution was a series of ozone monitoring instruments, beginning with the SBUV/TOMS instrument on Nimbus 7 in 1978. The Aura instruments and a series of SBUV/2 instruments on NOAA satellites have continued this critical monitoring function. The Antarctic ozone hole has proven to be a very sensitive indicator of the state of the ozone layer. The high spatial resolution measurements, first by TOMS and continued by OMI, have been particularly important in mapping the development of the Antarctic ozone hole each year. These current and recent results are a prominent aspect of the quadrennial ozone depletion assessment that is written for the parties to the Montreal Protocol. In Fig. 9, the most recent ozone hole from 2017 is shown as measured by OMI, based on the monthly average from October. 

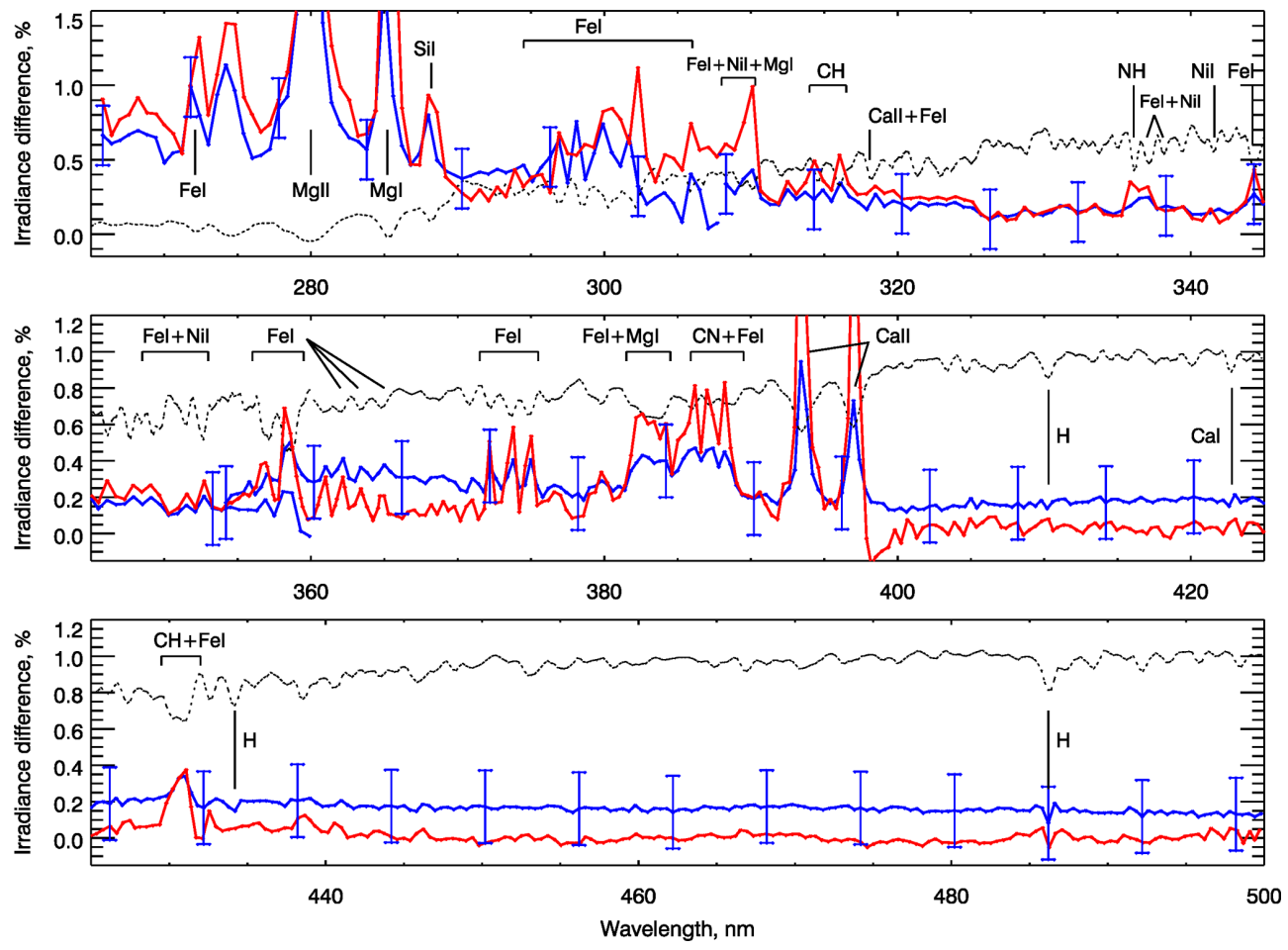

Figure 8. Solar spectral irradiance (SSI) variability in cycle 24. The blue line shows the normalized long-term difference (2012-2014 vs. 2007-2009, i.e., the solar maximum vs. solar minimum) as observed by OMI with representative $\pm 0.2 \%$ errors. The red line follows the properly normalized GOME-2 data derived from the rotational ( $\sim 27$ days, the local maximum flux vs. the adjacent minimum) variability in 2012-2013. The GOME-2 data were adjusted to the OMI SSI by a multiplicative factor that matches the 27-day and solar cycle amplitudes in the 325-335 $\mathrm{nm}$ range. Note that the $\sim 3$ times higher GOME-2 spectral resolution leads to substantially higher SSI amplitudes at prominent spectral lines and blends (e.g., CaII 393, $396 \mathrm{~nm}$ ). For reference, the scaled solar spectrum is shown as a dotted line.

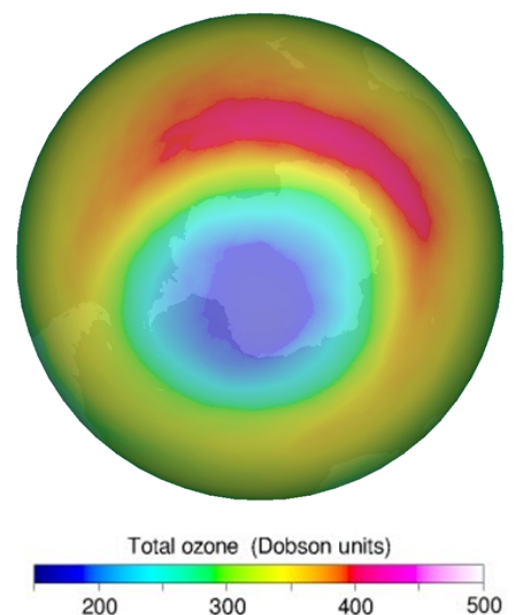

Figure 9. October 2017 monthly average OMI total ozone column over Antarctica.

\subsection{The OMI long-term ozone data record}

The data record of total column ozone from OMI has proven to be very stable over the 10 plus years of operation. This sta- bility is shown three ways (McPeters et al., 2015): by direct monitoring of instrument performance, by comparing OMI ozone with that from ground-based measurements, and by comparison with ozone from other satellite systems.

OMI instrument stability is monitored by tracking instrument parameters such as onboard measured solar flux (see Dobber et al., 2008b and Schenkeveld et al., 2017). Stability is also monitored by tracking changes in geophysical parameters like average ice reflectivity in Greenland and Antarctica. All these parameters show that OMI has been far more stable than any of the previous TOMS instruments. Two distinct algorithms have been used to compute total column ozone from OMI, a TOMS-type algorithm and a DOAS algorithm (Veefkind et al., 2006). A variation of the version 8 TOMS algorithm (Bhartia, 2007) used to process data from the series of TOMS instruments has been used for the OMITOMS retrieval. Designated the v8.5 algorithm, the most significant enhancement is that the longer wavelengths measured by OMI are used to infer cloud height on a sceneby-scene basis. OMI-TOMS ozone results are shown here. A comparison of OMI-TOMS and OMI-DOAS total ozone products can be found in Kroon et al. (2008). 


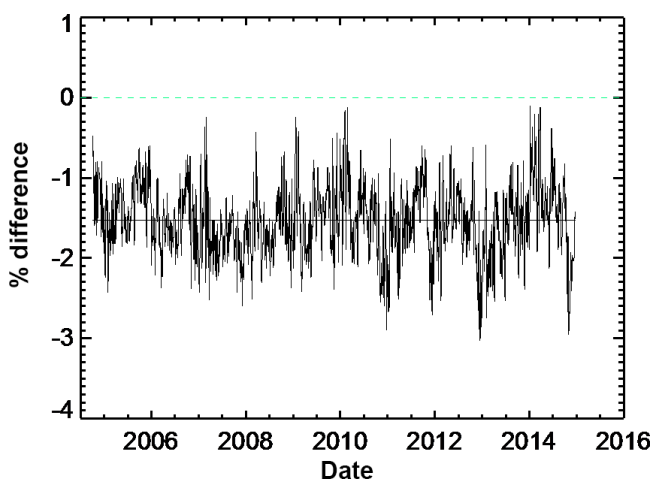

Figure 10. Weekly mean percent difference of OMI ozone minus ground-based averages from an ensemble of 76 Northern Hemisphere Dobson-Brewer stations with linear fit (from McPeters et al., 2015).

Comparisons with ground-based observations show that OMI has been very stable (see Fig. 10). Such comparisons have been shown to be capable of detecting instrument changes of a few tenths of a percent (Labow et al., 2013). The linear fit in Fig. 10 shows that OMI has almost no drift in ozone relative to the ground observations $(0.05 \%$ per decade). The offset of about $-1.5 \%$ is mostly caused by the use of the older Bass and Paur (1984) ozone cross sections in the OMI retrievals rather than the newer Brion-DaumontMalicet ozone cross sections (Brion et al., 1993).

Figure 11 shows comparisons of OMI ozone with data from a series of SBUV/2 instruments flying on NOAA spacecraft. The radiances from SBUV instruments on NOAA 16, 17,18 , and 19 were carefully analyzed and adjusted to create a consistent ozone data series. Here global average ozone from $60^{\circ} \mathrm{S}$ to $60^{\circ} \mathrm{N}$ is plotted as well as percent difference for each instrument. The first thing to note is the high degree of consistency of the four NOAA instruments. There is a small trend of OMI relative to SBUV of about $+0.4 \%$ per decade and an average bias of $-0.9 \%$. While this trend might be considered statistically significant, at the half percent per decade level, it is not possible to say whether one trend is more accurate than the other.

Similar comparisons with ozone from instruments on European satellites can be used to see if the behavior of OMI ozone displays similar patterns. The GTO (GOMEtype Total Ozone) merged ozone data record is based on data from sensors on GOME/ERS-2 (1995-2011), SCIAMACHY/ENVISAT (2002-2012), and GOME- 2/METOPA (2007-present). The GTO analysis combines these measurements into a continuous and homogeneous monthly mean time series (Coldewey-Egbers et al., 2015). In Fig. 12, OMI ozone averaged from $60^{\circ} \mathrm{S}$ to $60^{\circ} \mathrm{N}$ is compared with the v8.6 merged ozone data (MOD) time series based on a best effort merger of the NASA SBUV/2 data shown in Fig. 11 (Frith et al., 2014) and with this GTO time series. The OMI bias relative to GTO is a bit larger, $-1.7 \%$ vs. $-1.0 \%$

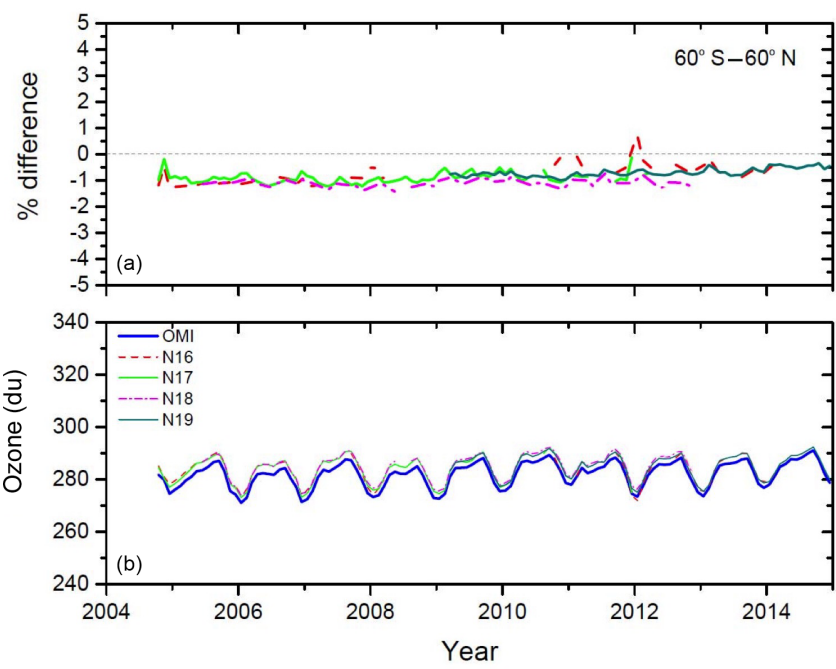

Figure 11. Total column ozone from OMI and four NOAA SBUV instruments (b) and differences in percent of OMI minus each SBUV instrument (a; adapted from McPeters et al., 2015).

for MOD over the same time period, again mostly due to cross section differences. OMI has a small positive trend relative to MOD over the 2004-2011 time period, and a small negative trend relative to GTO of $-0.85 \%$ per decade. Given the difficulty of maintaining long-term calibration of multiinstrument data sets, differences of $1 \%$ or so per decade are probably the best one can do, and these differences should be considered within the range of uncertainty. An accuracy of $1 \%$ is sufficient to detect decadal trends in stratospheric ozone recovery, which are of the same order of magnitude, and is more than sufficient to detect recovery of ozone in the Antarctic ozone hole (Eyring et al., 2010; Chipperfield et al., 2017). Note that for monitoring long-term changes in stratospheric ozone, assimilated total ozone columns are often used, which have the benefit that long-term drifts in satellite measurements and inter-satellite differences are accounted for (van der A et al., 2010, 2015).

With regard to the first OMI science question (is the ozone layer recovering as expected?), OMI has contributed as expected. However, to fully address this question, data from other instruments that are designed to provide high vertical resolution ozone sounding and other constituents in the stratosphere (such as the Aura MLS) are needed (e.g., Strahan and Douglass, 2017). In addition, future UV nadir mappers such as GOME-2, OMPS mapper and profiler, and TROPOMI will be needed to continue the long-term total ozone record later into this century as the ozone layer continues to recover.

OMI total ozone column measurements have also been used as an integral part of the Multi Sensor Reanalysis (MSR) data sets version 1 (MSR-1; van der A et al., 2010) and version 2 (MSR-2; van der A et al., 2015). The MSR-2 data set is a 43-year total ozone column assimilation data set 

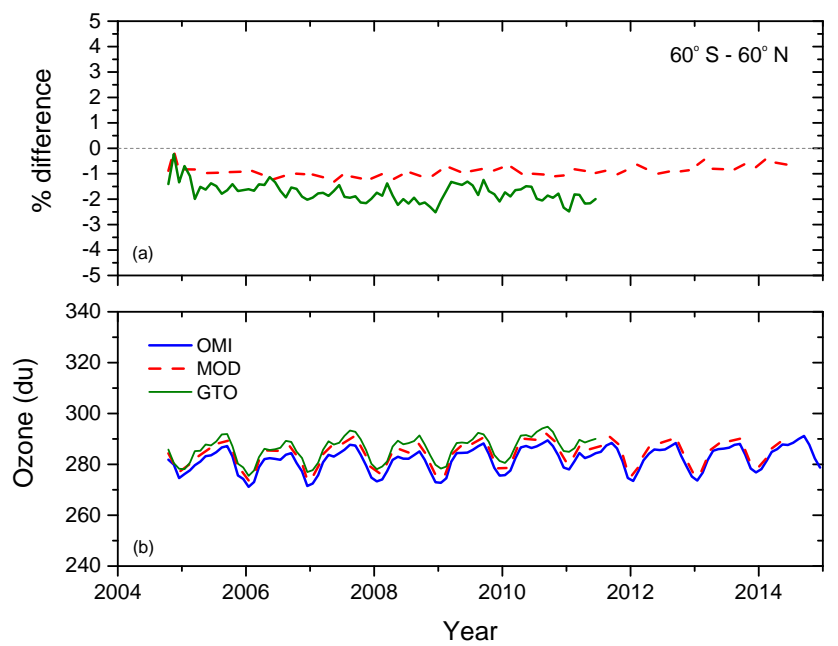

Figure 12. Total column ozone from OMI, the MOD (merged ozone data) based on SBUV/2 instruments, and the GTO (GOME-type Total Ozone) merged ozone based on GOME instruments and SCIAMACHY (b) and differences in percent of OMI minus each (a; from McPeters et al., 2015).

for 1970-2012 based on a multitude of satellite instruments measuring total ozone columns and provides global daily fields of total ozone columns. In Fig. 13, a time series is given with ozone hole images (for selected years) of the September mean total ozone column over Antarctica based on the MSR2 assimilated total ozone column data (van der A et al., 2015) for 1979-2012 in blue, and OMI assimilated total ozone columns for 2013-2017 indicated in grey. The red colors denote the 6 years that are known to have been disturbed by naturally occurring planetary wave activity, which lead to reduced seasonal Antarctic stratospheric ozone destruction (de Laat et al., 2017). Images and daily total ozone column data are obtained from the TEMIS website (http://www.temis.nl, last access: 5 April 2018). The MSR data sets have been used to monitor atmospheric processes affecting long-term local total ozone column variability (Knibbe et al., 2014) as well as long-term changes in Antarctic stratospheric ozone (ozone hole) and recovery (Knibbe et al., 2014; de Laat et al., 2015, 2017). Detection of recovery of Antarctic stratospheric ozone has turned out to be complicated due to ambiguities in Antarctic ozone hole metrics and analysis methods (Knibbe et al., 2014; de Laat et al., 2015). However, de Laat et al. (2017), using more robust Antarctic ozone hole metrics like the ozone mass deficit (OMD), show that after the year 2000, Antarctic stratospheric ozone recovery appears to be well under way. After reaching maximum ozone destruction around the year 2000, current levels of seasonal Antarctic stratospheric ozone destruction appear to have returned to early 1990s levels. In addition, the MSR data are also used for the annual World Meteorological Organization (WMO) Antarctic ozone bulletins that provide regular seasonal analy- ses of the status of the Antarctic ozone hole of that particular year (e.g., Braathen, 2015).

\subsection{Global surface UV radiation}

Surface UV estimates based on OMI satellite data continue the long-term TOMS UV record. The OMI UV algorithm (Tanskanen et al., 2006) was further developed from the TOMS algorithm (Eck et al., 1995; Krotkov et al., 1998, 2001). It consists of a calculation for the clear-sky case with corrections for clouds (or non-absorbing aerosols). Several validation studies of both TOMS and OMI-UV data have shown a positive bias in many locations affected significantly by absorbing aerosols (e.g., Arola et al., 2005; Tanskanen et al., 2007; Zempila et al., 2016). Correction for the absorbing aerosols was suggested by Arola et al. (2009), which exploits monthly aerosol climatology of Kinne et al. (2013). This correction is currently also implemented in the OMI UV product. Figure 14 gives an example of the OMI UV product, showing the long-term seasonal mean of the fall season (September-November) UV index, calculated from the 10-year OMI record (2005-2015). OMI UV data records have also provided valuable information for UV chapters of the WMO Scientific Assessment of Ozone Depletion both in 2006 and 2010 (Bais et al., 2007; Douglass et al., 2011). Note that the MSR-1 data set has also been used to provide a global daily UV-related information for the clear-surface clear-sky UV index and the clear-sky UV daily dose (van Geffen et al., 2017).

\section{Tropospheric ozone from OMI: overview of different methods}

Tropospheric ozone is an important pollutant at ground level, plays a critical role in oxidation and atmospheric chemistry, and is a greenhouse gas in the upper troposphere. As the retrieval of tropospheric ozone is a challenging (strongly ill posed) task, several approaches have been developed to overcome the challenges. OMI has fostered a large number of tropospheric ozone data products, both as ozone column amounts and ozone profiles. These products, as shown in Fig. 15, have been developed using either OMI measurements alone or in conjunction with other satellite measurements to improve sensitivity to near-surface ozone (e.g., Bowman, 2013; Cuesta et al., 2013; Hache et al., 2014) as summarized below. They have been used in tropospheric research (e.g., Sauvage et al., 2007; Ziemke et al., 2010; Cooper et al., 2014), for example to show evidence of decadal increases or trends in global tropospheric ozone, El Nino events during Aura (e.g., Chandra et al., 2009; Blunden and Ardnt, 2016), the 1-2 month Madden-Julian oscillation (Ziemke et al., 2015, and references therein), and urban pollution (Kar et al., 2010). It will be possible to employ similar approaches with other advanced sensors such as TROPOMI 


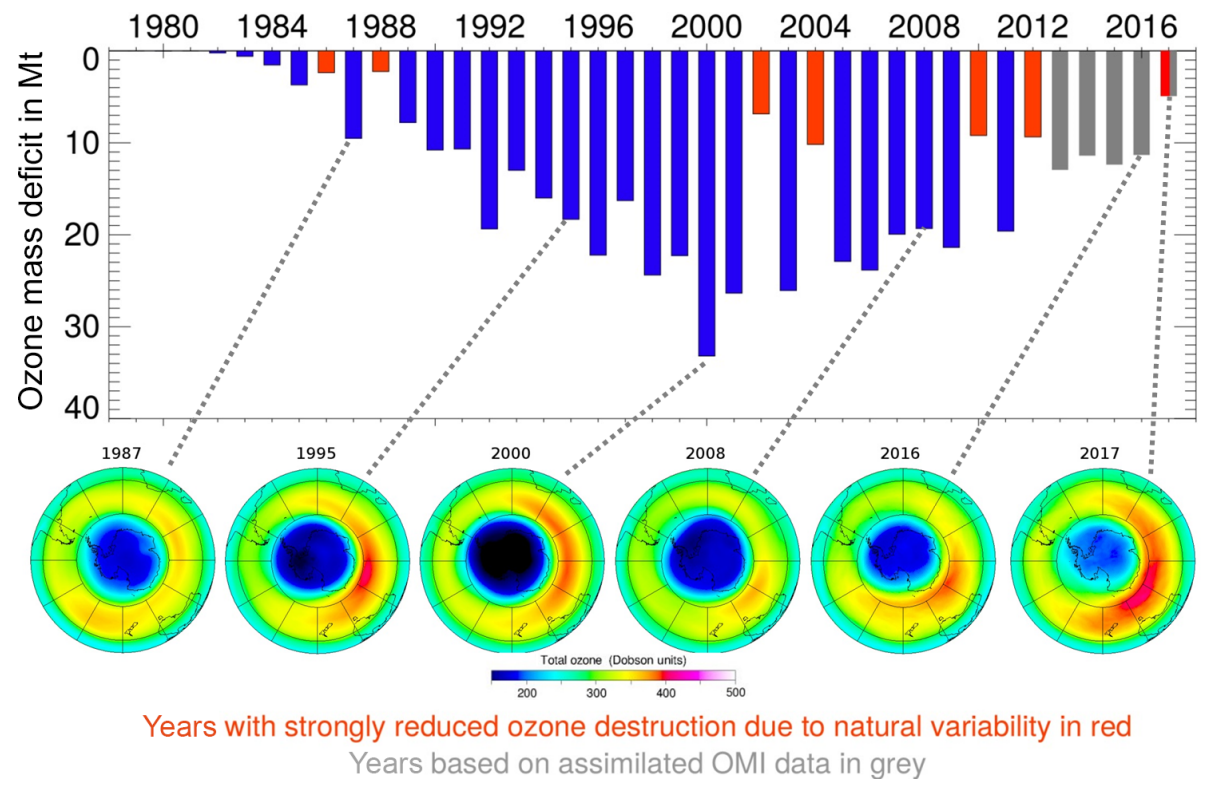

Figure 13. Annual September average daily ozone mass deficit (OMD) over Antarctic relative to the 220 DU total ozone column level, the most common total ozone column threshold value for calculating the OMD (see Sect. 6.1 for an explanation of OMD).

(a) OMI UV index mean at local noon time for Autumn 2013

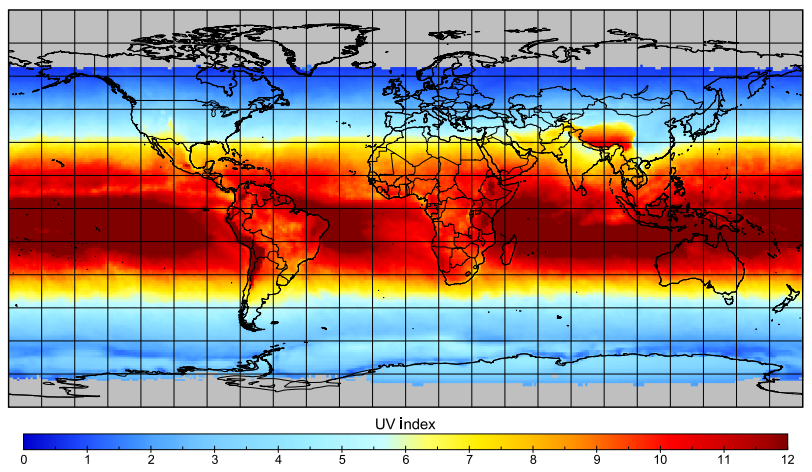

(b) OMI UV index mean at local noon time on 16/10/2013

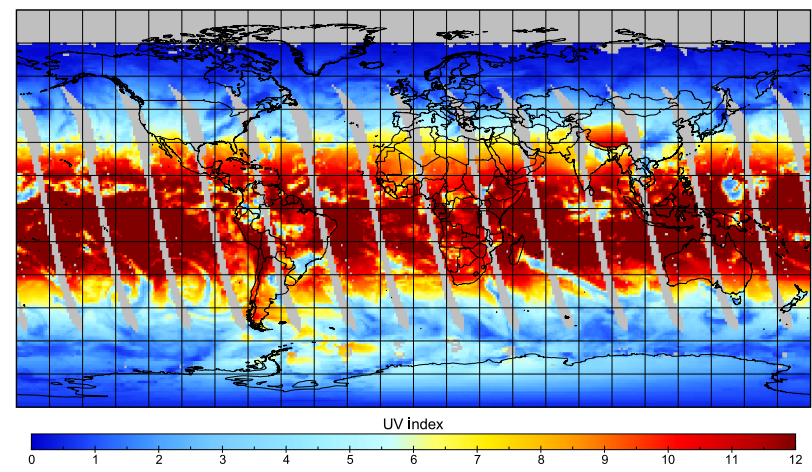

Figure 14. (a) Three-month mean UV index from OMUVB in the boreal fall season 2013 (September-November). (b) Global map of daily UV index on 16 October 2013 showing exceptionally high UV index values in Patagonia due to the stretched ozone hole.

and the OMPS limb profiler as well as the future geostationary sensors. This will allow for continued monitoring of global long-term trends in tropospheric ozone.

Regional biases in tropospheric ozone are up to 5-10 DU between the three products and the Global Modeling Initiative (GMI) model in Fig. 15. Ziemke et al. (2014) included an extensive ozonesonde analysis to estimate both biases and precision uncertainties. Figures 2-7 of Ziemke et al. (2014) indicate biases and precisions (all in DU) of $-4.0 \pm 6.3$ for ASSIM, $+1.7 \pm 7.0$ for PROF, $-7.1 \pm 7.0$ for TRAJ, and $-0.2 \pm 6.6$ for GMI, as calculated from daily coincident ozonesonde measurements. Biases between the three products and the GMI model in some regions, such as the tropical Pacific (Fig. 15), may exceed both monthly and seasonal precisions (i.e., standard error of the means) of $\sim 1-2$ DU from the ozonesondes. Despite biases of up to $5 \mathrm{DU}$ or greater in Fig. 15, all three products and the GMI model correctly prescribe the large zonal wave-1 pattern of $\sim 20 \mathrm{DU}$ in the tropics and very similar regional amplitudes and gradients in both hemispheres.

\subsection{Cloud slicing}

The convective-cloud differential method (Ziemke et al., 1998) uses the differences between OMI total column ozone and OMI above-cloud column ozone under conditions of high reflectivity (i.e., deep convective clouds) to estimate a tropospheric column ozone residual. The convective-cloud differential algorithm is simple to apply but not very effective for measuring tropospheric ozone outside the tropics. 

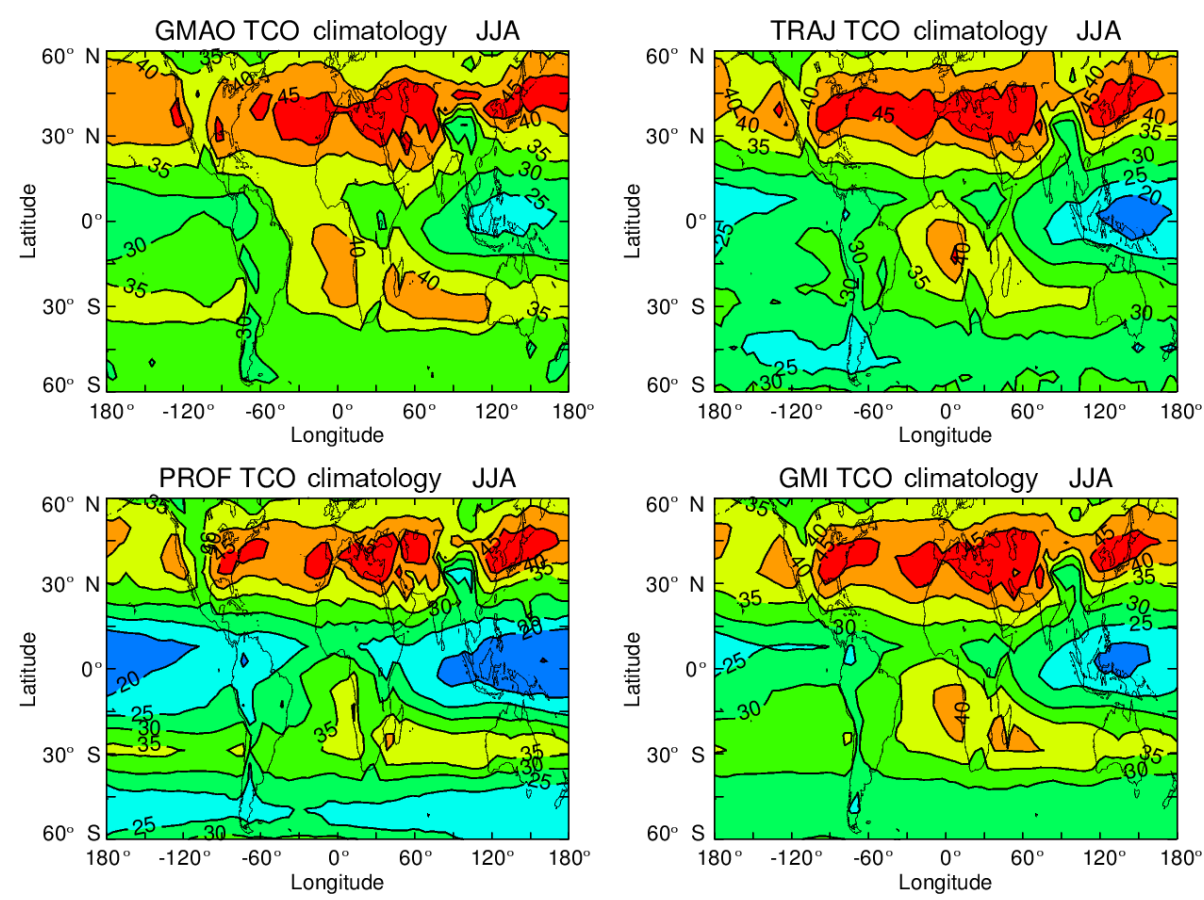

Figure 15. June-July-August (JJA) seasonal climatology of tropospheric column ozone (in Dobson units) for three OMI/MLS products and the Global Modeling Initiative (GMI) chemical transport model. GMAO denotes assimilated OMI/MLS, TRAJ is trajectory-mapped OMI/MLS, and PROF is derived from the OMI-only profile retrieval method of Liu et al. (2010a) and Huang et al. (2017). This figure is from Ziemke et al. (2014) which includes references and detailed descriptions for these three products and the GMI model.

Measuring tropospheric ozone outside tropical latitudes is possible to accomplish by using either an OMI-only profile algorithm, or the neural network approach (Sellitto et al., 2011), or by combining OMI with other satellite measurements. Some of these are discussed in more detail below.

\subsection{Profile retrieval algorithms}

Strong spectral variation in both ozone absorption (decrease by $\sim 4$ orders of magnitude from the Hartley to Huggins bands) and Rayleigh scattering $\left(\sim \lambda^{-4}\right)$ lead to wavelengthdependent photon penetration, and therefore provide vertical discrimination of ozone in the atmosphere (Bhartia et al., 1996). Temperature-dependent ozone absorption in the Huggins bands adds additional tropospheric ozone information (Chance et al., 1991). Based on these principles, two ozone profile algorithms were implemented: the operational algorithm (OMO3PR) at KNMI (Kroon et al., 2011; Mielonen et al., 2015) and the research algorithm (PROFOZ) at the US Smithsonian Astrophysical Observatory (SAO; Liu et al., 2010a, b; Kim et al., 2013). Both retrieve ozone profiles from the spectral region $270-330 \mathrm{~nm}$ using the optimal estimation method, but they differ significantly in implementation details including radiometric calibration, radiative transfer model simulation, a priori constraint, retrieval grids, and retrieval parameters. Typically, the retrievals have 5-7 degrees of freedom (DOF) for signals of ozone with up to $\sim 1.5 \mathrm{DOF}$ in the troposphere. It has been shown that tropospheric ozone column can be directly and accurately retrieved in the few Dobson units range from OMI data alone on the spatial pixelto-pixel basis, but successful retrievals of tropospheric ozone and further capture of tropospheric ozone trends require accurate forward model simulation, well-characterized prior information, and consistently accurate radiometric calibration over the entire record (Liu et al., 2010a, b; Mielonen et al., 2015).

Validation of the OMO3PR product by Kroon et al. (2011) showed that the operational retrieval agrees well with high vertical resolution limb viewing satellite observations, including MLS, TES, GOMOS, the Stratospheric Aerosol and Gas Experiment (SAGE-II), the Optical Spectrograph and InfraRed Imaging System (OSIRIS), and ozone soundings to within $20 \%$ but with some biases. These biases can be slightly reduced using a different a priori constraint and surface albedo assumptions; most of the biases are likely caused by systematic biases in radiative-transfer modeling and radiometric calibrations (Mielonen et al., 2015). Tang and Prather (2012) indicated that this product has some skill in identifying stratosphere-troposphere folds. The methods employed by the TROPOMI ozone profile algorithm will be used to update the current OMI ozone profile algorithm (de Haan, 2015).

For PROFOZ, early versions were partially evaluated against ozonesonde, aircraft, MLS, surface measurements, 
model simulations, and tropospheric ozone derivations from other methods (Pittman et al., 2009; Liu et al., 2010b, 2013a; Zhang et al., 2010; Walker et al., 2010; Tarasick et al., 2010; Sellitto et al., 2011; Wang et al., 2011, 2013; Bak et al., 2013a, b, 2015; Flynn et al., 2014; Foret et al., 2014; Ziemke et al., 2014). The analyses generally showed good agreement with other correlative data but revealed limited sensitivity to ozone in the lower troposphere and near the surface. In addition to these evaluations, the PROFOZ product has been used to study dynamical and chemical features associated with stratospheric-tropospheric exchange, to evaluate the transport of anthropogenic pollution (Pittman et al., 2009; Liu et al., 2010a, 2013b; Walker et al., 2010; Su et al., 2011), to constrain tropospheric ozone sources (Zhang et al., 2010; Kim et al., 2013), to initialize boundary conditions for air quality modeling (Pour-Biazare et al., 2011), and to study ozone enhancement in the lower troposphere over central and eastern China (Hayashida et al., 2015, 2016).

\subsection{Multi-instrument retrievals}

The Aura MLS measures ozone profiles along an orbital track from the top of the atmosphere down to the tropopause or upper troposphere. Several schemes have been used to derive tropospheric ozone by combining OMI and MLS. Jing et al. (2006) and Ziemke et al. (2006) subtracted MLS stratospheric column ozone from OMI total column ozone to derive tropospheric column ozone residual. While Jing et al. (2006) applied a criterion for near-coincidence between OMI and MLS along orbital track, Ziemke et al. (2006) used a 2-D interpolation technique to fill in missing MLS measurements between orbital tracks and improve horizontal coverage. Schoeberl et al. (2007) further used a wind trajectory mapping technique of MLS ozone profiles and Yang et al. (2007) used potential vorticity mapping to obtain better signal-to-noise ratio and horizontal coverage for the OMI/MLS tropospheric column ozone. Wargan et al. (2015) discusses an OMI/MLS ozone profile product derived using data assimilation; it is noted that current MERRA-2 (Gelaro et al., 2017; Wargan et al., 2017) analyses include ozone profiles determined similarly via data assimilation of Aura MLS and OMI ozone. A comparison of several OMI/MLS tropospheric column ozone products (data assimilation, trajectory mapping, and profile retrieval methods) is described by Ziemke et al. (2014). They concluded that the assimilation was overall the best science product when considering temporal and spatial coverage and ability to provide an entire ozone profile for both troposphere and stratosphere.

Theoretical studies point towards the potential of combining UV Hartley-Huggins (270-330 nm) and thermal infrared (TIR) $\mathrm{O}_{3}(9.6 \mu \mathrm{m})$ bands for retrieving ozone profiles (Landgraf and Hasekamp, 2007; Worden et al., 2007). The physical basis for the improved resolution is that the reflected sunlight radiances are sensitive to the tropospheric column, whereas the TIR sounders are primarily sensitive to the free- troposphere. The "subtraction" of the free tropospheric column from the total column results in an estimate of nearsurface concentrations. The theory has been demonstrated by a suite of retrieval algorithms: GOME-2/IASI (Cuesta et al., 2013) and OMI/TES (Fu et al., 2013) for ozone profile retrievals. The MUlti-SpEctra, MUlti-SpEcies, MUltiSEnsorS (MUSES) tropospheric ozone retrieval algorithm is implemented to extend the joint TES/OMI retrievals to the AIRS/OMI combination (Fu et al., 2016, 2018; Miyazaki et al., 2018).

\section{Research data products}

Several new products have been developed after launch that were not part of the initial suite of standard products described in Levelt et al. (2006b). Here we describe some of these research and new standard products. Most of these are available through the Aura Validation Data Center (AVDC), https://avdc.gsfc.nasa.gov (last access: 5 April 2018). While these products have been demonstrated with OMI, they can be continued with instruments such as TROPOMI and UV/VIS sensors on geostationary satellites.

\subsection{Aerosol above cloud}

Contrary to the known cooling effects of these aerosols in cloud-free scenarios over dark surfaces, the overlapping situation of absorbing aerosols over cloud can potentially exert a significant level of atmospheric absorption and produces a positive radiative forcing (warming) at the top of the atmosphere. The magnitude of direct radiative effects of aerosols above cloud directly depends on the aerosol loading, microphysical and optical properties of the aerosol layer, and the underlying cloud deck and geometric cloud fraction. The optical depth of carbonaceous and desert dust aerosol layers located above clouds (ACAOD) has been retrieved with OMI (Torres et al., 2012) leading to a global daily product spanning the OMI ACAOD record (OMACA). OMACA can be used to improve our understanding of aerosol-cloud interaction. OMACA provides both the above-cloud aerosol optical depth as well as the optical depth of the underlying clouds layer using OMI measurements at 354 and $388 \mathrm{~nm}$ (Jethva et al., 2016). Evaluation of the product using highquality measurements from the first phase of the NASA Earth Venture Suborbital (EV-S) ObseRvations of Aerosols above CLouds and their intEractionS (ORACLES) field campaign is in progress.

\subsection{Water vapor column}

Water vapor has a very important role in the atmosphere as being the most important natural greenhouse gas and the driver of the hydrological cycle. Water vapor has a set of absorption bands in the visible region of the spectra measured by OMI. Despite being much weaker than other bands 
at longer wavelengths, they can be used to retrieve water vapor, as demonstrated first by Wagner et al. (2013). A new column water vapor product (OMH2O) has been developed, evaluated, and implemented (Wang et al., 2014). Wang et al. $(2014,2016)$ show global maps and comparisons with other independent global data sets. The version 1.0 product, retrieved using a fitting window of 430-480 nm, compared reasonably well with GPS, AERONET, SSMIS and GlobVapour data, but had a significant low bias over the ocean. The version 2 OMI water vapor product was developed using a fitting window of $427.7-465 \mathrm{~nm}$ and improved the agreement with the reference data sets (Wang et al., 2016). The evaluation results show that the OMI data track the seasonal and interannual variability of the water vapor column for a wide range of climate regimes. A new version of the OMI water vapor product is expected in the near future that will make use of updated spectroscopic data on water vapor and liquid water absorption.

\subsection{Glyoxal column}

Glyoxal (CHO-CHO) is a short-lived product of nonmethane volatile organic compound (NMVOC) atmospheric oxidation, a process that is important for both air quality and climate. The combination of formaldehyde and glyoxal measurements can provide useful information on NMVOC speciation (DiGangi, 2012; Chan Miller et al., 2016) and can constrain NMVOC emissions (Stavrakou et al., 2009). Glyoxal has been retrieved from OMI (Chan Miller et al., 2014, 2016) using wavelengths $435-461 \mathrm{~nm}$. The retrieval of glyoxal is challenging due to its very weak absorption (optical depths on the order of $10^{-4}$ to $10^{-3}$ ). The OMI glyoxal research product is optimized to minimize interferences from stronger absorbers. The retrieval consists of three steps, (1) slant column density (SCD) fitting in the visible spectral region (435$461 \mathrm{~nm}$ ), (2) air mass factor calculations to convert SCDs into vertical column densities, and (3) de-striping using a reference sector over the Sahara (Chan Miller et al., 2014). Nearly 10 years of glyoxyl data (up to 2014) are available. Given the challenging nature of glyoxal retrievals, detector degradation affects the quality of the retrievals after 2013 (Chan Miller et al., 2016).

\section{$8.4 \mathrm{NO}_{2}$ cloud slicing}

The use of cloud pressure information from OMI has led to so-called cloud slicing approaches to retrieve profile information about trace gases. While this approach has most commonly been applied to ozone (see Sect. 7), it has also been applied to $\mathrm{NO}_{2}$ with OMI to derive information about its concentration in the free troposphere (Choi et al., 2014; Belmonte Rivas et al., 2015). In addition, other approaches have been applied to isolate $\mathrm{NO}_{2}$ generated from lightning (Bucsela et al., 2010; Pickering et al., 2016).

\subsection{Specialized data sets}

As the first generation of OMI trace gas products typically used static databases for profile information, specialized products emerged to meet various needs of the user community. Several examples apply to $\mathrm{NO}_{2}$ and $\mathrm{SO}_{2}$ and in some cases these were enabled by information provided in the standard products (e.g., Lamsal et al., 2008, 2015; Yang et al., 2010; Lee et al., 2011; Russell et al., 2011, 2012; McLinden et al., 2014; Theys et al., 2014; De Smedt et al., 2015). At the same time, this research has driven improvements in the standard products.

\subsection{Polar mesospheric clouds}

Another valuable but unplanned data product is the detection and characterization of polar mesospheric clouds (PMCs). These clouds (also called noctilucent clouds) are observed at $80-85 \mathrm{~km}$ altitude and high latitudes $\left(>50^{\circ}\right)$ during summer in each hemisphere and are potentially another indicator of long-term climate change (Thomas, 1996). Backscatter ultraviolet instruments such as OMI detect PMCs as an enhanced signal at short wavelengths (DeLand et al., 2010). The broad cross-track coverage of OMI makes it possible to directly characterize local time variations in PMC occurrence frequency and intensity (DeLand et al., 2011). PMCs can also affect derived values of profile ozone in the upper stratosphere, so that a correction is required to obtain better results (Bak et al., 2016).

\section{Multi-platform product and analyses using several instruments across platforms}

The development of the so-called "A-train", a constellation of satellites in a common afternoon orbit all flying within about $15 \mathrm{~min}$ of each other, has provided unique opportunities to combine data from different instruments into new products, to incorporate additional information to enhance existing OMI products, and to cross validate other products with OMI. Among the satellites used in conjunction with the OMI, the A-train includes the NASA Aqua satellite, that hosts MODIS, AIRS, and the Clouds and the Earth's Radiant Energy System (CERES); the CALIPSO, a joint US (NASA) and French (CNES) satellite mission that includes the Cloud-Aerosol Lidar with Orthogonal Polarization (CALIOP) instrument; the millimeter-wavelength cloud radar aboard the NASA CloudSat; and the CNES Polarization \& Anisotropy of Reflectances for Atmospheric Sciences coupled with Observations from a Lidar (PARASOL) that carried the Polarization and Directionality of the Earth's Reflectances (POLDER) instrument that was operational from 2004-2013. Data from other satellites not in a common orbit provide additional opportunities to enhance and eventually extend OMI data. Similar approaches are possible with sensors in other constellations such as the Suomi NPP platform 
that hosts the Visible Infrared Imaging Radiometer Suite (VIIRS) and OMPS that will fly in tandem with the S5P TROPOMI and multiple geostationary hosting UV/VIS spectrometers (TEMPO, GEMS, Sentinel-4 UVN) along with higher spatial resolution visible imagers such as the Japan Aerospace Exploration Agency (JAXA) Geostationary Meteorological Satellite (GMS) Himawari, the Geostationary Operational Environmental Satellite (GOES) R Series Advanced Baseline Imager (ABI), and Meteosat Third Generation Flexible Combined Imager (FCI).

In addition to the examples provided below, there are numerous works that employ cross-platform comparisons for evaluation of OMI and other satellite data sets and algorithms. For example, Veefkind et al. (2011) used spatial and temporal correlations between concurrent satellite observations of aerosol optical thickness (AOT) from MODIS and OMI tropospheric columns of $\mathrm{NO}_{2}, \mathrm{SO}_{2}$, and $\mathrm{HCHO}$ to infer information on the global composition of aerosol particles. Other studies that use cross-platform data sets together for synergetic analyses for volcanic eruption and studies of air pollution include Carn et al., 2007a; Witte et al., 2011; Hsu et al., 2012; Wang et al., 2013. Studies specifically for aerosol include Carboni et al. (2012), Chen et al. (2012), Lacagnina et al. (2015), and Jethva et al. (2014b), and Zhu et al. (2016) for HCHO. Examples of combining ozone information from different platforms are given in Sect. 7.3.

\subsection{OMI field of view for collocation}

To aid in the interpretation of OMI data and use them in conjunction with other instruments, it is important to have a precise estimate of its field of view (FOV). To this end, in depth comparisons of collocated OMI and MODIS radiances have been conducted (de Graaf et al., 2016; Sihler et al., 2017). Results show that the OMPIXCOR product $75 \mathrm{FoV}$ corner coordinates are accurate as the full width at half maximum (FWHM) of a super-Gaussian FOV model when this function is assumed. These studies are anticipated to help expand the work of de Graaf et al. (2012) by allowing for the use of collocated OMI and MODIS data to compute the aerosol direct effect over clouds among other applications.

\subsection{A-train collocated products}

The OMI team has developed collocated products that aid in algorithm development and validation. These include a new standard product that contains both OMI cloud products as well as many Aqua MODIS statistical cloud parameters collocated to OMI footprints known as OMMYDCLD. Over the past 2 years, working closely with aerosol algorithm developers, the team also produced a new level 2 orbital track product (OMMYDAGEO) that collocates OMI geo-coordinates (row and scan number) onto the MODIS granule on 3 and $10 \mathrm{~km}$ scales. This product assists users with the computationally burdensome task of collocating data from these two instru- ments, providing a direct link between the MODIS and OMI aerosol data products at two different spatial resolutions.

\subsection{Aerosol products}

Aerosol products have benefitted from the A-train in several ways. For example, in the OMAERUV aerosol product, data from the CALIOP have been used to constrain the aerosol layer heights, and carbon monoxide (CO) data from AIRS have been used to help distinguish different types of absorbing aerosol, i.e., smoke from dust (Torres et al., 2013). MODIS data (OMMYDCLD) have been used to evaluate the effect of subpixel cloud contamination (Gassó and Torres, 2016). AOTs from MODIS have also been combined with OMI measurements to estimate aerosol layer height (Satheesh et al., 2009; Chimot et al., 2017).

Another important science application of the OMI and A-train aerosol products is the first global estimate of the shortwave direct radiative effect of aerosols at the top of the atmosphere (TOA-DREA) over land and ocean (Lacagnina et al., 2016). This work was carried out using data based on global satellite observations of SSA, phase function, and AOD from PARASOL, in synergy with OMI SSA retrievals. Aerosol information from these two sensors is combined with the land-surface bidirectional reflectance distribution function (BRDF) and cloud properties from MODIS to produce monthly mean TOA-DREA global monthly averages in 2006. The estimated global mean TOA-DREA is $-4.6 \pm 1.5 \mathrm{~W} \mathrm{~m}^{-2}$ for cloud-free and $-2.1 \pm 0.7 \mathrm{~W} \mathrm{~m}^{-2}$ for all-sky conditions. All-sky TOA-DREA is less negative than its cloud-free counterpart, because of enhanced planetary albedo by clouds and cloud masking effects on aerosol radiation interactions. These are the first DREA estimates constrained by satellite-based aerosol absorption observations.

The instantaneous TOA-DREA over clouds can be obtained by combining level 1 radiance measurements in the shortwave from OMI with radiance measurements from MODIS on the A-train. The instantaneous TOA-DREA over clouds can be estimated very accurately using hyper spectral radiances of aerosol and clouds scenes (de Graaf et al., 2014), which can be achieved by combining OMI and MODIS radiances. The instantaneous TOA-DREA over clouds can reach values up to $130 \pm \mathrm{W} \mathrm{m}^{-2}$, which results in strong warming of the atmosphere at the location of the aerosol layer.

\subsection{Clouds and radiation}

The two OMI cloud algorithms are based on oxygen dimer absorption at $477 \mathrm{~nm}$ (Acarreta et al., 2004; Veefkind et al., 2016) and rotational-Raman scattering at $350 \mathrm{~nm}$ (Joiner and Vasilkov, 2006), both related to photon path lengths in the atmosphere (Stammes et al., 2008). The A-train has provided unique opportunities to help interpret and evaluate these measurements. Radiative transfer calculations using collocated cloud extinction profiles from MODIS and CloudSat 
have been used to evaluate the OMI retrievals (Vasilkov et al., 2008). In addition, a third photon path length type measurement (from PARASOL measurements of oxygen absorption in the $\mathrm{O}_{2} \mathrm{~A}$ band) provided additional measurements for evaluation (Sneep et al., 2008).

These works demonstrated that the cloud pressures derived from OMI and similar path length type measurements do not measure the physical cloud top but rather an average pressure reached by solar photons inside a cloud. This pressure has been referred to as the optical centroid cloud pressure (OCCP) where the centroid relates to the vertical distribution of cloud reflectance. This led to the development of fast simulators that can be used to estimate OCCP based on vertical extinction profiles from either models or measurements such as those provided by CloudSat/MODIS (Joiner et al., 2012).

The OMI OCCPs were shown to be distinct from estimates of the physical cloud top provided by infrared, radar, or lidar (e.g., Joiner et al., 2006; Ziemke et al., 2009; Avery et al., 2010). This then led to the development of an approach to detect multi-layer clouds using OMI OCCP in combination with cloud top pressures from Aqua MODIS (Joiner et al., 2010). Vasilkov et al. (2010) showed that optically thick clouds over snow and ice can be detected using the difference between retrieved OMI OCCP and the surface pressure. Finally, it has been noted that the effective cloud fraction (ECF), a standard parameter in the OMI cloud products, is nearly linearly related to top of the atmosphere shortwave radiative flux (TOA-SWF; Gupta et al., 2016). They used nearly coincident estimates of TOA-SWF from the Aqua CERES along with OMI and other ancillary parameters to train an artificial neural network (ANN) to estimate TOASWF. This relationship is also exploited by the surface solar irradiance product from OMI (http://www.temis.nl/ssi, last access: 5 April 2018), which is validated against the globally distributed Baseline Surface Radiation Network (BSRN) measurements (Wang et al., 2014).

\subsection{Trace gases}

Besides the work on volcano monitoring (Sect. 4) and estimated emissions using data from multiple platforms (Sect. 3.4), deriving trace gas concentrations from polarorbiting satellite platforms that have different equator crossing times can provide information about diurnal variability. It is important that these types of cross-platform analyses use a common algorithm. This has been accomplished for $\mathrm{NO}_{2}$ using OMI and SCIAMACHY (Boersma et al., 2008).

DeSmedt et al. (2015) have studied the diurnal variability of formaldehyde (HCHO) by joint analysis of GOME-2 morning and OMI afternoon measurements using the same retrieval algorithm for both instruments ${ }^{3}$. They find that in the morning the formaldehyde observations are higher than

\footnotetext{
${ }^{3}$ Data are available at the TEMIS website (http://h2co. aeronomie.be, last access: 5 April 2018).
}

in the afternoon over tropical rainforests in the Amazon basin, Africa, and Indonesia. In urban areas at mid-latitudes higher formaldehyde values are found in the afternoon; however, the authors point out that this is probably partly driven by the better spatial resolution of the afternoon observations by OMI.

Joint analysis of stratospheric $\mathrm{NO}_{2}$ measured by the Odin/OSIRIS limb viewing instrument (Haley and Brohede, 2007) and OMI column $\mathrm{NO}_{2}$ to improve the tropospheric $\mathrm{NO}_{2}$ column have been demonstrated by Adams et al. (2016) by analyzing 1 year of data from OSIRIS along with a photochemical box model to account for diurnal variations of stratospheric $\mathrm{NO}_{2}$ and the temporal mismatch in observations. The authors conclude that in order to fully exploit the advantage of the methodology, further work is needed to understand all biases between the instruments. This work shows the potential to combine information from polar and geostationary platforms.

Over eastern Asia, Verstraeten et al. (2015) showed that strong increases between 2005 and 2010 in $\mathrm{OMI} \mathrm{NO}_{2}$ columns can been used to quantify the contribution of photochemical ozone formation to the rapid increase in midtropospheric ozone concentrations over and downwind of that region. Their study demonstrated that the good vertical sensitivity of OMI to ozone precursors down to the Earth's surface can be combined with the sensitivity of the TES instrument to mid-tropospheric ozone, to arrive at a more comprehensive understanding of spatio-temporal patterns in tropospheric ozone.

\subsection{Geometry-dependent Lambertian equivalent reflectivity}

For most OMI algorithms, it is important to have accurate estimates of surface reflectance. Surface reflectance is complex because it varies with the sun-satellite viewing geometry as well as with time and space. Vasilkov et al. (2017) constructed a global time-varying geometry-dependent Lambertequivalent reflectivity (GLER) product (i.e., for each OMI pixel) based on MODIS data and ocean models. This allows for integration into existing algorithms based on Lambertequivalent reflectivity models without any major modifications to the algorithms. The GLER was tested within OMI $\mathrm{NO}_{2}$ and cloud retrievals and found to have a significant impact (Vasilkov et al., 2017). The GLER approach can also be applied to other UV/VIS instruments.

\section{OMI validation using field campaign data}

OMI data have been used to support flight planning for many international field campaigns and conversely data from these campaigns has helped to validate OMI retrievals. Successful OMI validation field campaigns provide data to aid in relating surface observations to retrieved OMI column in- 
formation. Campaigns including a series of Aura Validation Experiments (AVE; Schoeberl et al., 2008), DANDELIONS (Brinksma et al., 2008), and INTEX-B (Singh et al., 2009) have achieved this using vertically integrated aircraft and lidar data, and also by using measurements from a multi-axis differential optical absorption spectroscopy (MAX-DOAS) type instrumentation that produce OMI-comparable column amounts of trace gases and aerosols. Some examples of OMI retrieval improvements derived directly from using validation campaign data include Lee et al. (2009) for $\mathrm{SO}_{2}$ and Hains et al. (2010) for $\mathrm{NO}_{2}$.

There are several challenges common to most field campaign data when applied to satellite validation. One of the biggest issues for an airborne campaign is measurement repeatability, that is, does the aircraft measure over the same locations within an acceptable proximity to satellite overpass time for multiple days? Often flight patterns are designed to capture specific types of air pollution plumes and thus are sporadic in both time and space. The recent Atmospheric Tomagraphy Mission (ATom) is a notable exception to this approach with a fixed global flight circuit covering multiple seasons and years (Prather et al., 2018).

OMI validation is also heavily reliant upon wellestablished ground networks of instruments measuring columns of $\mathrm{NO}_{2}, \mathrm{SO}_{2}, \mathrm{HCHO}, \mathrm{O}_{3}, \mathrm{UV}$, and aerosols. AERONET for aerosol optical depth (Torres et al., 2007; Ahn et al., 2014), Brewer-Dobson network for total ozone column (Labow et al., 2013; McPeters et al., 2015), SHADOZ for ozone profiles (Thompson et al., 2012), the Pandora spectrometer network (Tzortziou et al., 2013), the Pandonia network (Müller et al., 2017), and many other networks have all been used for measuring a wide range of OMI-relevant trace gases and aerosols useful for OMI validation. It is essential for these networks to have consistent standards in site setup, retrieval method, and data processing.

Here, we discuss the Deriving Information on Surface Conditions from Column and Vertically Resolved Observations Relevant to Air Quality (DISCOVER-AQ) campaign relevant to $\mathrm{OMI} \mathrm{NO}_{2}$ and $\mathrm{O}_{3}$ and the Cabauw Intercomparison campaign for Nitrogen Dioxide measuring Instruments (CINDI and CINDI-2) campaigns in more depth. These campaigns address these challenges by including consistent, repeatable sampling (DISCOVER-AQ) and in the case of CINDI-2, a rigorous instrument intercomparison protocol.

\subsection{DISCOVER-AQ}

The DISCOVER-AQ project was a 4-year NASA Earth Venture Suborbital mission to improve the use of satellites to monitor air quality for public health and environmental benefit. Through targeted airborne and ground-based observations, DISCOVER-AQ aimed at improving the interpretation of satellite observations to diagnose near-surface conditions relating to air quality. Deployments took place over the Washington, DC and Baltimore, MD metropolitan area in July 2011, in the San Joaquin Valley of California in winter 2013, and two warm season campaigns followed in Houston, Texas in September 2013 and in the Denver/Front Range region of Colorado in July/August 2014. Two aircraft were used: the NASA P-3B for in situ sampling typically from 0.3 to $3 \mathrm{~km}$ altitude in a spatially consistent pattern of spiral ascents and descents and the NASA UC-12 flying at $\sim 8 \mathrm{~km}$ with remote sensing instruments for trace gases and aerosols. Extensive ground observations were used to measure air pollution at the surface using in situ observations, and aloft using balloons and remote sensing instruments including a network of Pandora spectrometers. They provided continuous (every $20 \mathrm{~s}$ ) high-resolution measurements of total column $\mathrm{NO}_{2}$ and $\mathrm{O}_{3}$ amounts at a minimum of 12 urban and rural locations.

The OMI standard product tropospheric $\mathrm{NO}_{2}$ retrieval version 2.1 was compared with the vertical integration of the Baltimore/Washington DISCOVER-AQ P-3B aircraft data and the ground-based Pandora retrievals (Lamsal et al., $2014)$. OMI agreed with the aircraft data to within $\pm 20 \%$ in $60 \%$ of the cases at four of six sites, while there was a greater difference at two sites near coastal areas that have complex vertical and horizontal distributions of $\mathrm{NO}_{2}$. On average the OMI columns were less than those from the aircraft by 6 to $22 \%$ except at the two coastal sites, where the aircraft column was often a factor of 2 greater. OMI total column $\mathrm{NO}_{2}$ was less than Pandora by $<6 \%$ at three sites and greater than Pandora by $9-13 \%$ at two sites.

Pandora total columns of $\mathrm{O}_{3}$ and $\mathrm{NO}_{2}$ were compared with those from OMI at all 12 sites in the Baltimore/Washington region by Tzortziou et al. (2013). Pandora total column $\mathrm{NO}_{2}$ varied by an order of magnitude spatially and temporally with distinct diurnal and weekly patterns in polluted areas. The $\mathrm{NO}_{2}$ column average difference between Pandora and OMI ranged from -0.17 to +0.05 DU with OMI mostly showing underestimates, particularly in urbanized areas where pollution sources were located close to measurement sites. For total column $\mathrm{O}_{3}$ the average differences were $<12$ DU (or $3.9 \%$ ) with OMI greater than Pandora. Reed et al. (2015) also compared Pandora with OMI during the Baltimore/Washington campaign and found that OMI pixel size, clouds, and aerosols affected OMI retrievals causing differences between Pandora and OMI of up to $65 \%$ for total column $\mathrm{NO}_{2}$ and $23 \%$ for total column $\mathrm{O}_{3}$.

The Airborne Compact Atmospheric Mapper (ACAM) flew on the NASA UC-12 aircraft during the Baltimore/Washington DISCOVER-AQ campaign, yielding highresolution $\left(1.5 \times 1.1 \mathrm{~km}^{2}\right)$ DOAS $\mathrm{NO}_{2}$ retrievals for columns below the aircraft. Slant columns are converted to vertical columns (Lamsal et al., 2017) using $\mathrm{NO}_{2}$ profiles from a high-resolution regional air quality model and bidirectional reflectivity distribution function data from MODIS. ACAM retrievals compared well with vertically integrated in situ data (See Fig. 16). ACAM demonstrated intra-urban spatial variability that cannot be captured with OMI, revealing a factor of 4 subpixel variability seen within some OMI pixels. 


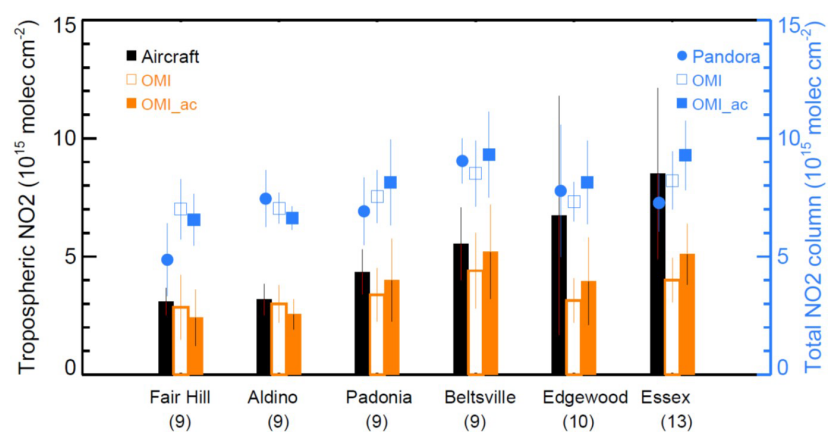

Figure 16. Comparison of average tropospheric (orange bars) and total (blue squares) $\mathrm{NO}_{2}$ columns determined from in situ aircraft (black bars) measurements and total columns retrieved from Pandora (filled blue circles) at the six locations in Maryland during the DISCOVER-AQ field campaign (from Lamsal et al., 2014). Open bars and squares represent the operational retrievals and filled bars and squares represent the retrievals performed using collocated aircraft-measured $\mathrm{NO}_{2}$ vertical profiles. The vertical lines represent the standard deviation of the average.

Ozonesondes were launched typically twice a day during DISCOVER-AQ flight days from two sites in the Baltimore/Washington area. Total column $\mathrm{O}_{3}$ from the sondes averaged $3 \%$ greater than OMI columns (Thompson et al., 2014), which considering the $5 \%$ sonde uncertainty is not statistically significant. The sonde data were also compared with trajectory-mapped OMI minus MLS tropospheric $\mathrm{O}_{3}$ residual (surface to $200 \mathrm{hPa}$; Schoeberl et al., 2008), yielding a statistically significant average discrepancy of $10 \%$.

The KNMI patented $\mathrm{NO}_{2}$ sonde, known as the $\mathrm{NO}_{2}$-sonde, (Sluis et al., 2010) was operated on a tethered balloon platform and was used to fill a critical gap between the ground level and the lowest extent of the NASA P3-B aircraft that regularly made spiral flights over the $\mathrm{NO}_{2}$-sonde site. The $\mathrm{NO}_{2}$-sonde data can be combined with the $\mathrm{NO}_{2}$ measurement from the NCAR NOxyO3 instrument on board the P3$\mathrm{B}$ as both use chemiluminescence and have a sampling rate of $1 \mathrm{~Hz}$. The combined vertical profiles of $\mathrm{NO}_{2}$ in the nearsurface layer offer the opportunity to test the assumptions of $\mathrm{NO}_{2}$ profile shape that are used in both models and the OMI retrieval of $\mathrm{NO}_{2}$.

These data sets were used in two ways to examine OMI $\mathrm{NO}_{2}$ retrievals. The combined aircraft-sonde data were first used to create a pseudo-column for comparison with OMI and Pandora located at the Huron, CA site in January 2013. Second, a combined aircraft-sonde profile was created for the afternoon profile taken on 22 January 2013 compared to the a priori model profile shape to analyze the possible error in assumed profile shape as compared to the "actual" profile shape measured by the sonde and aircraft. The well-mixed afternoon boundary layer in this case led to a small calculated error in column amount of $8 \%$ as shown in Fig. 17.

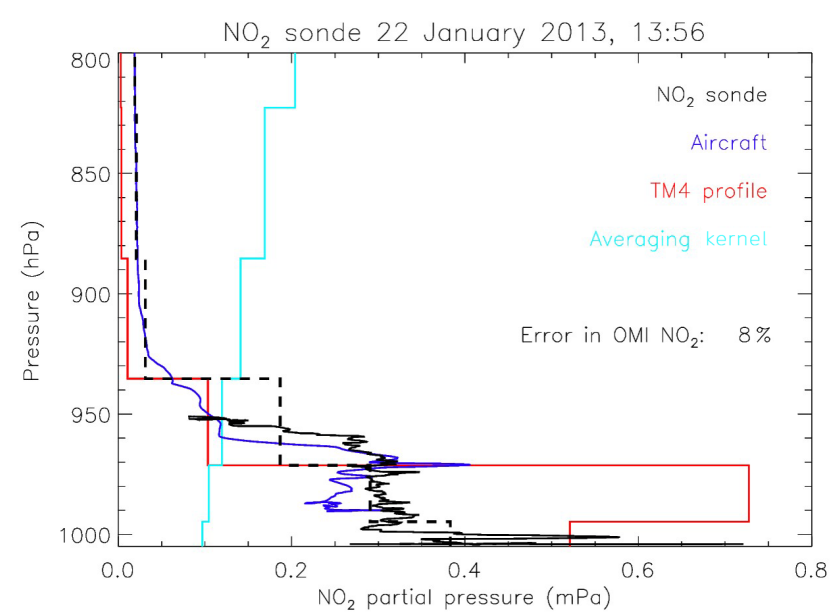

Figure 17. Comparison of $\mathrm{NO}_{2}$ vertical profile obtained from KNMI $\mathrm{NO}_{2}$-sonde to in situ aircraft profile, TM4 model profile and OMI (DOMINO) averaging kernel for OMI pixel covering the DISCOVER-AQ site in Huron, California on 22 January 2013.

\subsection{CINDI and CINDI-2}

For the validation of space-borne observations of $\mathrm{NO}_{2}$ and other trace gases from hyperspectral imagers like OMI, ground-based instruments using the MAX-DOAS technique (Hönniger et al., 2004; Wittrock et al., 2004) are an excellent choice, since they rely on similar retrieval techniques employed for observations from orbit. In both cases, retrievals take into account the light path of scattered sunlight though the entire atmosphere. To ensure proper traceability of the MAX-DOAS observations, a thorough intercomparison is mandatory, which is one of the goals of both the Cabauw Intercomparison campaign for Nitrogen Dioxide measuring Instruments (CINDI) and CINDI-2 campaigns.

The Cabauw Experimental Site for Atmospheric Research (CESAR; Apituley et al., 2008) site in the center of the Netherlands was the stage for CINDI in June-July 2009 (Piters et al., 2012). The location is under the influence of both clean and polluted air masses. Here, a wide range of observations were routinely carried out that fulfill the requirement to provide the background necessary to unravel the differences between the observations from different MAXDOAS instruments that can be quite diverse in design and data treatment. These observations include observations to understand the light paths, i.e., in situ aerosol observations of optical and microphysical properties, as well as vertical profiles of aerosol optical properties by (Raman) lidar (Apituley et al., 2009; Donovan and Apituley, 2013; de Haij et al., 2007). In addition, vertical profiles of $\mathrm{NO}_{2}$ were measured during CINDI using the then newly developed $\mathrm{NO}_{2}-$ sonde (Sluis et al., 2010), and a $\mathrm{NO}_{2}$ lidar system (Volten et al., 2009). This approach proved to be highly successful and results were described in papers collected in a special issue (Roscoe et al., 2010). Although no direct OMI validation was 
performed using data collected during CINDI, the campaign was crucial in establishing the performance and requirements of the ground-based instruments (e.g., Lamsal et al., 2014; Irie et al., 2012).

With the Sentinel-5 Precursor TROPOMI and its nadir pixel size of $7.0 \times 3.5 \mathrm{~km}^{2}$, together with recent developments in MAX-DOAS instruments (e.g., Ortega et al., 2015), there was a need for a follow-up MAX-DOAS intercomparison campaign. Thus CINDI-2, which was completed in September 2016, had the following goals: (1) to assess the consistency of slant column measurements of key target species $\left(\mathrm{NO}_{2}, \mathrm{O}_{3}, \mathrm{O}_{4}\right.$, and $\left.\mathrm{HCHO}\right)$ relevant for the validation of TROPOMI and the future ESA atmospheric Sentinels using a large number of DOAS and MAX-DOAS instruments from all over the world, (2) to study the relationship between remote sensing column and profile measurements of those species and reference measurements of the same species, and (3) to investigate the horizontal representativeness of MAXDOAS measuring systems in view of their use for the validation of satellite tropospheric measurements on the scale of 25-50 km². During CINDI-2, 36 MAX-DOAS instruments participated. A feature of recent MAX-DOAS developments is the ability to use azimuthal scanning, in addition to elevation scanning, such as in, for example, the Pandora type of instruments (Herman et al., 2009).

To support the campaign goals, $\mathrm{NO}_{2}$ profiles were again provided by $\mathrm{NO}_{2}$-sondes and lidar, as well as through in situ observations and other ancillary observations situated in and around the Cabauw meteorological tower as depicted in Fig. 18. Extensive aerosol information was gathered using Raman lidar as well as by in situ samplers. The rigorous semi-blind comparison methods and strict data protocol for all instruments that participated in CINDI-2 as described in Kreher et al. (2017) ensure that this group of MAX-DOAS type instruments will form a reliable global network for both OMI and TROPOMI validation.

\section{Conclusions}

OMI was successfully launched on NASA's EOS-Aura satellite on 15 July 2004 and continues to deliver a huge amount of satellite data for studying the ozone layer, air quality, and climate change. In this paper, we have given an overview of the instrument's exceptional capabilities and we have highlighted the scientific and operational applications obtained using OMI data. Detailed results can be found in the papers in this OMI special issue and other publications. Due to the broad user community and worldwide use of OMI data in the scientific as well as the operational domain, the complete set of results obtained with OMI data extend far beyond the reach of this special issue.

OMI is the first instrument that is able to obtain daily global coverage combined with unprecedented spatial resolution, sensing a high-resolution spectrum per ground pixel.

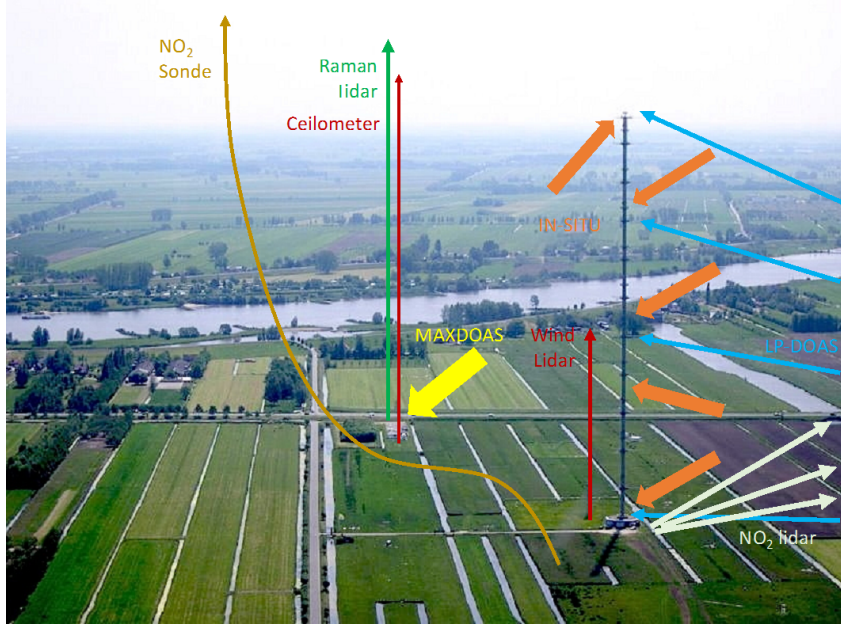

Figure 18. Schematic layout of the CINDI-2 campaign superimposed on an aerial picture of the CESAR site. Main instrument classes are indicated. The $\mathrm{NO}_{2}$-sondes were launched from close to the tower. A long-path DOAS was placed at a distance of about $4 \mathrm{~km}$ from the tower that was able to scan several retroreflectors at different altitude levels.

This technique, based on the use of a 2-dimensional detector and a unique optical design, is now being used in follow-on satellite instrumentation by European, American, and Asian space programs. Furthermore, OMI is exceptionally stable, more so than any previous UV/VIS satellite instrument.

In the unique trans-Atlantic collaboration between the Netherlands, Finland, and the United States, we were able to obtain a very successful international co-operation that enabled us to learn and improve our different techniques of analyses and interpret the satellite measurements. In this cooperation, the instrument and retrieval knowledge built up over the last 20 to 40 years, between the US and Europe, was exchanged and lead to mutual improvement and understanding of the measurements and their interpretation, with important outcomes for research on the chemical composition of the atmosphere. In particular, the development of retrievals with different approaches and application to the same instrumental data led not only to improvements of the retrieval algorithms but also to enormous advances in our understanding of the data and its accuracy.

The scientific exploitation of OMI data led to new insights and findings, especially in the air quality domain, mostly related to the high-resolution $\mathrm{NO}_{2}$ and $\mathrm{SO}_{2}$ measurements and their use for air quality forecasts, emission estimations, source attribution, and trend monitoring. Due to the development of the NRT and VFD data streams, the operational use of OMI data was much greater than expected. Examples include the use of OMI NRT data in the EU Copernicus CAMS project for ozone layer and air quality products, and the use of the NRT and VFD data for the VAACs for aviation rerouting in case of volcanic eruptions. 
There were also many positive unanticipated results with OMI data, such as the first ever observation of glyoxal from space, the use of the extremely stable OMI solar irradiance product by the solar irradiance community for monitoring the sun in relation to climate change, the development of highresolution emission source monitoring, and the unexpected strong correlation of OMI tropospheric $\mathrm{NO}_{2}$ column measurements with in situ, near-surface monitoring instruments in regional domains. In conclusion, as OMI extends far beyond its planned mission lifetime with more than 13 years of data, the impact of this broad-reaching data set will only continue to grow due to OMI's stability and owing to its connection with both past and future satellite missions.

Data availability. The data sets for all OMI standard products are listed in Table 1 with corresponding DOIs or URLs. There are several locations for accessing and downloading OMI data. The majority of level $1 \mathrm{~b}$, level $2(\mathrm{~g})$, and level 3 data products can be obtained via NASA archives including the Goddard Earth Sciences Data and Information Services Center (GES DISC; https://disc.sci.gsfc.nasa.gov/Aura/data-holdings/OMI; NASA, 2018) and the accompanying MIRADOR data search tool (https://mirador.gsfc.nasa.gov/; MIRADOR, 2018). OMI data can also be found at TEMIS (www.temis.nl; TEMIS, 2018). Additional, detailed level $1 \mathrm{~b}$ and instrument quality information can be found on the KNMI OMI website (http: //projects.knmi.nl/omi/research/calibration/instrument_status_v3/; KNMI OMI, 2018). VFD products produced by FMI can be found on the SAMPO site (http://sampo.fmi.fi/; SAMPO, 2018). The OMI Data User's Guide detailing all data products can be found with the following link: https://docserver.gesdisc.eosdis.nasa.gov/ repository/Mission/OMI/3.3_ScienceDataProductDocumentation/ 3.3.2_ProductRequirements_Designs/README.OMI_DUG.pdf (last access: 18 April 2018).

Competing interests. Bryan N. Duncan is a member of the ACP editorial board. Other than that, the authors declare that they have no conflict of interest.

Special issue statement. This article is part of the special issue "Ten years of Ozone Monitoring Instrument (OMI) observations (ACP/AMT inter-journal SI)". It is not associated with a conference.

Acknowledgements. The authors of this paper wish to thank everyone who has contributed to the successful OMI project (too numerous to mention them all), and especially the international OMI Science Team. The KNMI activities for OMI are funded by the Netherlands Space Office. US investigators acknowledge funding from several NASA programs including the Aura Science Team (NNH13ZDA001N-AURAST) and the NASA Solar Irradiance Science Team (NNH15CN67C). The Finnish co-authors are thankful for the funding from Tekes and the Academy of Finland, including the recent projects INQUIRE (267442), ILMApilot
(303876), CoE (312125), and SPARK.

Edited by: Michel Van Roozendael

Reviewed by:two anonymous referees

\section{References}

Acarreta, J. R., de Haan, J. F., and Stammes, P.: Cloud pressure retrieval using the $\mathrm{O}_{2}-\mathrm{O}_{2}$ absorption band at $477 \mathrm{~nm}$, J. Geophys. Res., 109, D05204, https://doi.org/10.1029/2003JD003915, 2004.

Adams, C., Normand, E. N., McLinden, C. A., Bourassa, A. E., Lloyd, N. D., Degenstein, D. A., Krotkov, N. A., Belmonte Rivas, M., Boersma, K. F., and Eskes, H.: Limb-nadir matching using non-coincident $\mathrm{NO}_{2}$ observations: proof of concept and the OMI-minus-OSIRIS prototype product, Atmos. Meas. Tech., 9, 4103-4122, https://doi.org/10.5194/amt-9-4103-2016, 2016.

Ahn C., Torres, O., and Bhartia, P. K.: Comparison of OMI UV Aerosol Products with Aqua-MODIS and MISR observations in 2006, J. Geophys. Res, 113, D16S27, https://doi.org/10.1029/2007JD008832, 2008.

Ahn, C., Torres, O., and Jethva, H.: Assessment of OMI near-UV aerosol optical depth over land, J. Geophys. Res., 119, 24572473, https://doi.org/10.1002/2013JD020188, 2014.

Apituley, A., Russchenberg, H., van der Marel, H., Boers, R., ten Brink, H., de Leeuw, G., Uijlenhoet, R., Arbresser-Rastburg, B., and Röckmann, T.: Overview of research and networking with ground based remote sensing for atmospheric profiling at the Cabauw experimental site for atmospheric research (CESAR) the Netherlands, in: Proceedings IGARSS 2008, Boston, Massachusetts, III, 903-906, 2008.

Apituley, A., Wilson, K. M., Potma, C., Volten, H., and de Graaf. M.: Performance assessment and application of Caeli - a highperformance Raman lidar for diurnal profiling of water vapour, aerosols and clouds, in: Proceedings of the 8th ISTP, edited by: Apituley, A., Russchenberg, H. W. J., and Monna, W. A. A., S06O10, 2009.

Arola, A., Kazadzis, S., Krotkov, N., Bais, A., Grübner, J., and Herman, J. R.: Assessment of TOMS UV bias due to absorbing aerosols, J. Geophys. Res., 110, D23211, https://doi.org/10.1029/2005JD005913, 2005.

Arola, A., Kazadzis, S., Lindfors, A., Krotkov, N., Kujanpää, J., Tamminen, J., Bais, A., di Sarra, A., Villaplana, J. M., Brogniez, C., Siani, A. M., Janouch, M., Weihs, P., Webb, A., Koskela, T., Kouremeti, N., Meloni, D., Buchard, V., Auriol, F., Ialongo, I., Staneck, M., Simic, S., Smedley, A., and Kinne, S.: A new approach to correct for absorbing aerosols in OMI UV, Geophys. Res. Lett., 36, L22805, https://doi.org/10.1029/2009GL041137, 2009.

Avery, M., Twohy, C., McCabe, D., Joiner, J., Severance, K., Atlas, E., Blake, D., Bui, T. P., Crounse, J., Dibb, J., Diskin, G., Lawson, P., McGill, M., Rogers, D. Sachse, G., Scheuer, E., Thompson, A. M., Trepte, C., Wennberg, P., and Ziemke, J.: Convective distribution of tropospheric ozone and tracers in the Central American ITCZ region: Evidence from observations during TC4, J. Geophys. Res., 115, D00J21 https://doi.org/10.1029/2009JD013450, 2010. 
Avnery, S., Mauzerall, D. L., Liu, J., and Horowitz, L. W.: Global crop yield reductions due to surface ozone exposure: 1. Year 2000 crop production losses and economic damage, Atmos. Environ., 45, 2284-2296, https://doi.org/10.1016/j.atmosenv.2010.11.045, 2011.

Bais, A. F., Lubin, D., Arola, A., Bernhard, G., Blumthaler, M., Chubarova, N., Erlick, C., Gies, H. P., Krotkov, N., Lantz, K., Mayer, B., McKenzie, R. L., Piacentini, R. D., Seckmeyer, G., Slusser, J. R., and Zerefos, C. S.: Surface Ultraviolet Radiation: Past, Present, and Future, WMO/UNEP ozone assessment, WMO, 2007.

Bak, J., Kim, J. H., Liu, X., Chance, K., and Kim, J.: Evaluation of ozone profile and tropospheric ozone retrievals from GEMS and OMI spectra, Atmos. Meas. Tech., 6, 239-249, https://doi.org/10.5194/amt-6-239-2013, 2013a.

Bak, J., Liu, X., Wei, J. C., Pan, L. L., Chance, K., and Kim, J. H.: Improvement of OMI ozone profile retrievals in the upper troposphere and lower stratosphere by the use of a tropopausebased ozone profile climatology, Atmos. Meas. Tech., 6, 22392254, https://doi.org/10.5194/amt-6-2239-2013, 2013b.

Bak, J., Liu, X., Kim, J. H., Chance, K., and Haffner, D. P.: Validation of OMI total ozone retrievals from the SAO ozone profile algorithm and three operational algorithms with Brewer measurements, Atmos. Chem. Phys., 15, 667-683, https://doi.org/10.5194/acp-15-667-2015, 2015.

Bak, J., Liu, X., Kim, J. H., Deland, M. T., and Chance, K.: Improvement of OMI ozone profile retrievals by simultaneously fitting polar mesospheric clouds, Atmos. Meas. Tech., 9, 45214531, https://doi.org/10.5194/amt-9-4521-2016, 2016.

Ball, W. T., Haigh, J. D., Rozanov, E. V., Kuchar, A., Sukhodolov, T., Tummon, F., Shapiro, A. V., and Schmutz, W.: High solar cycle spectral variation inconsistent with stratospheric ozone observations, Nat. Geosci., 9, 206-209, https://doi.org/10.1038/ngeo2640, 2016.

Bani, P., Oppenheimer, C., Varekamp, J. C., Quinou, T., Lardy, M., and Carn, S. A.: Remarkable geochemical changes and degassing at Voui crater lake, Ambae volcano, Vanuatu, J. Volcanol. Geoth. Res., 188, 347-357, https://doi.org/10.1016/j.jvolgeores.2009.09.018, 2009a.

Bani, P., Oppenheimer, C., Tsanev, V. I., Carn, S. A., Cronin, S. J., Crimp, R., Calkins, J. A., Charley, D., Lardy, M., and Roberts, T. R.: Surge in sulfur and halogen degassing from Ambrym volcano, Vanuatu, B. Volcanol., 71, 1159-1168, https://doi.org/10.1007/s00445-009-0293-7, 2009b.

Bani, P., Oppenheimer, C., Allard, P., Shinohara, H., Tsanev, V., Carn, S., Lardy, M., and Garaebeti, E.: First arc-scale volcanic $\mathrm{SO}_{2}$ budget for the Vanuatu archipelago, J. Volcanol. Geoth. Res., 211-212, 36-46, https://doi.org/10.1016/j.jvolgeores.2011.10.005, 2012.

Barkley, M. P., De Smedt, I., Van Roozendael, M., Kurosu, T. P., Chance, K., Arneth, A., Hagberg, D., Guenther, A., Paulot, F., Marais, E., and Mao, J.: Top-down isoprene emissions over tropical South America inferred from SCIAMACHY and OMI formaldehyde columns, J. Geophys. Res., 118, 6849-6868, https://doi.org/10.1002/jgrd.50552, 2013.

Bass, A. M. and Paur, R. J.: The ultraviolet cross-sections of ozone. I. The measurements, in: Proc. Quadrenniel Ozone Symp., Halkidiki, Greece, 3-7 September 1984, edited by: Zerefos, C. and Ghazi, A., Reidel, Dordecht, 606-616, 1984.
Bauwens, M., Stavrakou, T., Müller, J.-F., De Smedt, I., Van Roozendael, M., van der Werf, G. R., Wiedinmyer, C., Kaiser, J. W., Sindelarova, K., and Guenther, A.: Nine years of global hydrocarbon emissions based on source inversion of OMI formaldehyde observations, Atmos. Chem. Phys., 16, 1013310158, https://doi.org/10.5194/acp-16-10133-2016, 2016.

Bechle, M. J., Millet, D. B., and Marshall, J. D.: National Spatiotemporal Exposure Surface for $\mathrm{NO}_{2}$ : Monthly Scaling of a Satellite-Derived Land-Use Regression, 2000-2010, Environ. Sci. Technol., 49, 12297-12305, https://doi.org/10.1021/acs.est.5b02882, 2015.

Beckett, E. L., Duesing, K. Martin, C., Jones, P., Furst, J., King, K., Niblett, S., Yates, Z., Veysey, M., and Lucock, M.: Relationship between methylation status of vitamin D-related genes, vitamin D levels, and methyldonor biochemistry, J. Nutrit. Intermed. Metabol., 8-15, https://doi.org/10.1016/j.jnim.2016.04.010, 2016.

Beirle, S., Boersma, K. F., Platt, U., Lawrence, M. G., and Wagner, T.: Megacity emissions and lifetimes of nitrogen oxides probed from space, Science, 333, 1737-1739, https://doi.org/10.1126/science.1207824, 2011.

Beirle, S., Hörmann, C., Penning de Vries, M., Dörner, S., Kern, C., and Wagner, T.: Estimating the volcanic emission rate and atmospheric lifetime of $\mathrm{SO}_{2}$ from space: a case study for $\mathrm{Ki}$ lauea volcano, Hawai'i, Atmos. Chem. Phys., 14, 8309-8322, https://doi.org/10.5194/acp-14-8309-2014, 2014.

Belmonte Rivas, M., Veefkind, P., Eskes, H., and Levelt, P.: OMI tropospheric $\mathrm{NO}_{2}$ profiles from cloud slicing: constraints on surface emissions, convective transport and lightning $\mathrm{NO}_{x}$, Atmos. Chem. Phys., 15, 13519-13553, https://doi.org/10.5194/acp-1513519-2015, 2015.

Bernhard, G., Arola, A., Dahlback, A., Fioletov, V., Heikkilä, A., Johnsen, B., Koskela, T., Lakkala, K., Svendby, T., and Tamminen, J.: Comparison of OMI UV observations with ground-based measurements at high northern latitudes, Atmos. Chem. Phys., 15, 7391-7412, https://doi.org/10.5194/acp-157391-2015, 2015.

Bertaux, J. L., Kyrölä, E., Fussen, D., Hauchecorne, A., Dalaudier, F., Sofieva, V., Tamminen, J., Vanhellemont, F., Fanton d'Andon, O., Barrot, G., Mangin, A., Blanot, L., Lebrun, J. C., Pérot, K., Fehr, T., Saavedra, L., Leppelmeier, G. W., and Fraisse, R.: Global ozone monitoring by occultation of stars: an overview of GOMOS measurements on ENVISAT, Atmos. Chem. Phys., 10, 12091-12148, https://doi.org/10.5194/acp-10-12091-2010, 2010.

Bhartia, P. K.: OMI/Aura Ozone (O3) Total Column 1-Orbit L2 Swath 13x24 km V003, Greenbelt, MD, USA, Goddard Earth Sciences Data and Information Services Center (GES DISC), https://doi.org/10.5067/Aura/OMI/DATA2024, 2005.

Bhartia, P. K.: Total ozone from backscattered ultraviolet measurements, in: Observing Systems 20 for Atmospheric Composition, L'Aquila, Italy, 20-24 September, 2004, edited by: Visconti, G., Di Carlo, P., Brune, W., Schoeberl, M., and Wahner, A., Springer, 48-63, 2007.

Bhartia, P. K.: OMI/Aura Ozone (O3) Total Column Daily L2 Global Gridded 0.25 degree x 0.25 degree V3, , Goddard Earth Sciences Data and Information Services Center (GES DISC), https://doi.org/10.5067/Aura/OMI/DATA2025, 2012a. 
Bhartia, P. K.: OMI/Aura TOMS-Like Ozone, Aerosol Index, Cloud Radiance Fraction L3 1 day 1 degree x 1 degree V3, NASA Goddard Space Flight Center, Goddard Earth Sciences Data and Information Services Center (GES DISC), https://doi.org/10.5067/Aura/OMI/DATA3001, 2012b.

Bhartia, P. K.: OMI/Aura TOMS-Like Ozone and Radiative Cloud Fraction L3 1 day 0.25 degree x 0.25 degree V3, NASA Goddard Space Flight Center, Goddard Earth Sciences Data and Information Services Center (GES DISC), https://doi.org/10.5067/Aura/OMI/DATA3002, 2012c.

Bhartia, P. K., McPeters, R. D., Mateer, C. L., Flynn, L. E., and Wellemeyer, C.: Algorithm for the estimation of vertical ozone profiles from the backscattered ultraviolet technique, J. Geophys. Res., 101, 18793-718806, 1996.

Blunden, J., and Arndt, D. S. (Eds.): State of the Climate in 2015, B. Am. Meteorol. Soc., 97, S1-S275, 2016.

Bluth, G. J. S., Doiron, S. D. , Schnetzler, C. C., Krueger, A. J., and Walter, L. S.: Global tracking of the $\mathrm{SO}_{2}$ clouds from the June 1991 Mount Pinatubo eruptions, Geophys. Res. Lett., 19, 151-154, 1992.

Boersma, K. F., Jacob, D. J., Eskes, H. J., Pinder, R. W., Wang, J., and van der A, R. J.: Intercomparison of SCIAMACHY and OMI tropospheric $\mathrm{NO}_{2}$ columns: Observing the diurnal evolution of chemistry and emissions from space, J. Geophys. Res., 113, D16S26, https://doi.org/10.1029/2007JD008816, 2008.

Boersma, K. F., Jacob, D. J., Trainic, M., Rudich, Y., DeSmedt, I., Dirksen, R., and Eskes, H. J.: Validation of urban NO2 concentrations and their diurnal and seasonal variations observed from the SCIAMACHY and OMI sensors using in situ surface measurements in Israeli cities, Atmos. Chem. Phys., 9, 3867-3879, https://doi.org/10.5194/acp-9-3867-2009, 2009.

Boersma, K. F., Eskes, H. J., Dirksen, R. J., van der A, R. J., Veefkind, J. P., Stammes, P., Huijnen, V., Kleipool, Q. L., Sneep, M., Claas, J., Leitão, J., Richter, A., Zhou, Y., and Brunner, D.: An improved tropospheric $\mathrm{NO}_{2}$ column retrieval algorithm for the Ozone Monitoring Instrument, Atmos. Meas. Tech., 4, 19051928, https://doi.org/10.5194/amt-4-1905-2011, 2011.

Boersma, K. F., Vinken, G. C. M., and Tournadre, J.: Ships going slow in reducing their $\mathrm{NO}_{x}$ emissions: changes in 2005-2012 ship exhaust inferred from satellite measurements over Europe, Environ. Res. Lett., 10, 074007, https://doi.org/10.1088/17489326/10/7/074007, 2015.

Boscoe, F. P. and Schymura, M. J.: Solar ultraviolet-B exposure and cancer incidence and mortality in the United States, 1993-2002, BMC Cancer, 6, 264, https://doi.org/10.1186/1471-2407-6-264, 2006.

Bovensmann, H., Burrows, J. P., Buchwitz, M., Frerick, J., Noel, S., Rozanov, V. V., Chance, K. V., and Goede, A. P. H.: SCIAMACHY: Mission Objectives and Measurement Modes, J. Atmos. Sci., 56, 127-150, https://doi.org/10.1175/15200469(1999)056(0127:SMOAMM)2.0.CO;2, 1999.

Bowman, K. W.: Toward the next generation of air quality monitoring: Ozone, Atmos. Environ., 80, 571-583, https://doi.org/10.1016/j.atmosenv.2013.07.007, 2013.

Braathen, G.: WMO Antarctic Ozone Bulletin no. 5, Tech. Report, https://doi.org/10.13140/RG.2.1.1303.8165, 2015.

Brenot, H., Theys, N., Clarisse, L., van Geffen, J., van Gent, J., Van Roozendael, M., van der A, R., Hurtmans, D., Coheur, P.-F., Clerbaux, C., Valks, P., Hedelt, P., Prata, F., Rasson, O., Siev- ers, K., and Zehner, C.: Support to Aviation Control Service (SACS): an online service for near-real-time satellite monitoring of volcanic plumes, Nat. Hazards Earth Syst. Sci., 14, 10991123, https://doi.org/10.5194/nhess-14-1099-2014, 2014.

Brinksma, E. J., Pinardi, G., Volten, H., Braak, R., Richter, A., Schönhardt, A., van Roozendael, M., Fayt, C., Hermans, C., Dirksen, R. J., Vlemmix, T., Berkhout, A. J. C., Swart, D. P. J., Oetjen, H., Wittrock, F., Wagner, T., Ibrahim, O. W., de Leeuw, G., Moerman, M., Curier, R. L., Celarier, E. A., Cede, A., Knap, W. H., Veefkind, J. P., Eskes, H. J., Allaart, M., Rothe, R., Piters, A. J. M., and Levelt, P. F.: The 2005 and 2006 DANDELIONS $\mathrm{NO}_{2}$ and aerosol intercomparison campaigns, J. Geophys. Res., 113, D16S46, https://doi.org/10.1029/2007JD008808, 2008.

Brion, J., Chakir, A., Daumont, D., Malicet, J., and Parisse, C.: High resolution laboratory absorption cross section of $\mathrm{O}_{3}$ temperature effect, Chem. Phys. Lett., 213, 610-612, 1993.

Brook, J. R., Burnett, R. T., Dann, T. F., Cakmak, S., Goldbert, M. S., Fan, Z., and Wheeler, A. J.: Further interpretation of the acute effect of nitrogen dioxide observed in Canadian time-series studies, J. Expo. Sci. Env. Epid., 17, S36-S44, https://doi.org/10.1038/sj.jes.7500626, 2007.

Bucsela, E. J., Pickering, K. E., Huntemann, T. L., Cohen, R. C., Perring, A., Gleason, J. F., Blakeslee, R. J., Albrecht, R. I., Holzworth, R., Cipriani, J. P., Vargas-Navarro, D., MoraSegura, I., Pacheco-Hernández, A., and Laporte-Molina, S.: Lightning-generated $\mathrm{NO}_{x}$ seen by the Ozone Monitoring Instrument during NASA's Tropical Composition, Cloud and Climate Coupling Experiment (TC4), J. Geophys. Res., 115, D00J10, https://doi.org/10.1029/2009JD013118, 2010.

Bucsela, E. J., Krotkov, N. A., Celarier, E. A., Lamsal, L. N., Swartz, W. H., Bhartia, P. K., Boersma, K. F., Veefkind, J. P., Gleason, J. F., and Pickering, K. E.: A new stratospheric and tropospheric $\mathrm{NO}_{2}$ retrieval algorithm for nadir-viewing satellite instruments: applications to OMI, Atmos. Meas. Tech., 6, 26072626, https://doi.org/10.5194/amt-6-2607-2013, 2013.

Burney, J. and Ramanathan, V.: Recent climate and air pollution impacts on Indian agriculture, P. Natl. Acad. Sci. USA, 1111, 16319-16324, https://doi.org/10.1073/pnas.1317275111, 2014.

Burrows, J. P., Weber, M., Buchwitz, M., Rozanov, V., LadstätterWeißenmayer, A., Richter, A., Debeek, R., Hoogen, R., Bramstedt, K., Eichmann, K.-U., Eisinger, M., and Perner, D.: The Global Ozone Monitoring Experiment (GOME): Mission concept and first results, J. Atmos. Sci., 56, 151-175, 1999.

Campion, R., Martinez-Cruz, M., Lecoq, T., Caudron, C., Pacheco, J., Pinardi, G., Hermans, C., Carn, S. A., and Bernard, A.: Spaceand ground-based measurements of sulfur dioxide emissions from Turrialba volcano (Costa Rica), B. Volcanol., 74, 17571770, https://doi.org/10.1007/s00445-012-0631-z, 2012.

Canty, T. P., Hembeck, L., Vinciguerra, T. P., Anderson, D. C., Goldberg, D. L., Carpenter, S. F., Allen, D. J., Loughner, C. P., Salawitch, R. J., and Dickerson, R. R.: Ozone and NOx chemistry in the eastern US: evaluation of CMAQ/CB05 with satellite (OMI) data, Atmos. Chem. Phys., 15, 10965-10982, https://doi.org/10.5194/acp-15-10965-2015, 2015.

Carboni, E., Thomas, G. E., Sayer, A. M., Siddans, R., Poulsen, C. A., Grainger, R. G., Ahn, C., Antoine, D., Bevan, S., Braak, R., Brindley, H., DeSouza-Machado, S., Deuzé, J. L., Diner, D., Ducos, F., Grey, W., Hsu, C., Kalashnikova, O. V., Kahn, R., North, P. R. J., Salustro, C., Smith, A., Tanré, D., Torres, O., 
and Veihelmann, B.: Intercomparison of desert dust optical depth from satellite measurements, Atmos. Meas. Tech., 5, 1973-2002, https://doi.org/10.5194/amt-5-1973-2012, 2012.

Carn, S. A.: Multi-Satellite Volcanic Sulfur Dioxide L4 Long-Term Global Database V2, version 2, Greenbelt, MD, USA, Goddard Earth Science Data and Information Services Center (GES DISC), https://doi.org/10.5067/MEASURES/SO2/DATA402, 2015.

Carn, S. A. and Krotkov, N. A.: UV Satellite Measurements of Volcanic Ash, in: Volcanic Ash: Hazard Observation, edited by: Mackie, S., Cashman, K., Ricketts, H., Rust, A., and Watson, I. M., Elsevier, 217-231, https://doi.org/10.1016/B978-008-100405-0.00018-5, 2016.

Carn, S. A. and Lopez, T. M.: Opportunistic validation of sulfur dioxide in the Sarychev Peak volcanic eruption cloud, Atmos. Meas. Tech., 4, 1705-1712, https://doi.org/10.5194/amt-4-17052011, 2011.

Carn, S. A. and Prata, A. J.: Satellite-based constraints on explosive $\mathrm{SO}_{2}$ release from Soufrière Hills volcano, Montserrat, Geophys. Res. Lett., 37, L00E22, https://doi.org/10.1029/2010GL044971, 2010.

Carn, S. A., Krotkov, N. A., Yang, K., Hoff, R. M., Prata, A. J., Krueger, A. J., Loughlin, S. C., and Levelt, P. F.: Extended observations of volcanic $\mathrm{SO}_{2}$ and sulfate aerosol in the stratosphere, Atmos. Chem. Phys. Discuss., 7, 2857-2871, https://doi.org/10.5194/acpd-7-2857-2007, 2007a.

Carn, S. A., Krotkov, N. A., Krueger, A. J., Yang, K., and Levelt, P. F.: Sulfur dioxide emissions from Peruvian copper smelters detected by the Ozone Monitoring Instrument, Geophys. Res. Lett., 34, L09801, https://doi.org/10.1029/2006GL029020, 2007b.

Carn, S. A., Krueger, A. J., Krotkov, N. A., Arellano, S., and Yang, K.: Daily monitoring of Ecuadorian volcanic degassing from space, J. Volcanol. Geoth. Res., 176, 141-150, https://doi.org/10.1016/j.jvolgeores.2008.01.029, 2008.

Carn, S. A., Krueger, A. J., Krotkov, N. A., Yang, K., and Evans, K.: Tracking volcanic sulfur dioxide clouds for aviation hazard mitigation, Nat. Hazards, 51, 325-343, https://doi.org/10.1007/s11069-008-9228-4, 2009.

Carn, S. A., Froyd, K., Anderson, B. E., Wennberg, P., Crounse, J., Spencer, K., Dibb, J., Krotkov, N. A., Browell, E. V., Hair, J. W., Diskin, G., Sachse, G., and Vay, S.: Insitu measurements of tropospheric volcanic plumes in Ecuador and Colombia during TC4, J. Geophys. Res., 116, D00J24, https://doi.org/10.1029/2010JD014718, 2011.

Carn, S. A., Krotkov, N. A., Yang, K., and Krueger, A. J.: Measuring global volcanic degassing with the Ozone Monitoring Instrument (OMI), in: Remote Sensing of Volcanoes and Volcanic Processes: Integrating Observation and Modeling, edited by: Pyle, D. M., Mather, T. A., and Biggs, J., Geol. Soc. Lon, Special Publications, 380, https://doi.org/10.1144/SP380.12, 2013.

Carn, S. A., Clarisse, L., and Prata, A. J.: Multidecadal satellite measurements of global volcanic degassing, J. Volcanol. Geoth. Res., 311, 99-134, https://doi.org/10.1016/j.jvolgeores.2016.01.002, 2016.

Carn, S. A., Fioletov, V. E., McLinden, C. A., Li, C., and Krotkov, N. A.: A decade of global volcanic $\mathrm{SO}_{2}$ emissions measured from space, Sci. Rep., 7, 44095, https://doi.org/10.1038/srep44095, 2017.
Castellanos, P. and Boersma, K. F.: Reductions in nitrogen oxides over Europe driven by environmental policy and economic recession, Sci. Rep., 2, 265, https://doi.org/10.1038/srep00265, 2012.

Castellanos, P., Boersma, K. F., and van der Werf, G. R.: Satellite observations indicate substantial spatiotemporal variability in biomass burning $\mathrm{NO}_{\mathrm{x}}$ emission factors for South America, Atmos. Chem. Phys., 14, 3929-3943, https://doi.org/10.5194/acp14-3929-2014, 2014.

Cebula, R. P., Park, H., and Heath, D. F.: Characterization of the Nimbus-7 SBUV radiometer for the long-term monitoring of stratospheric ozone, J. Atmos. Ocean. Tech., 5, 215-227, 1988.

Chang N. B., Feng R., Gao Z. Q., and Gao W.: Skin cancer incidence is highly associated with ultraviolet-B radiation history, International Journal of Hygiene and Environmental Health, 213, https://doi.org/10.1016/j.ijheh.2010.06.006, 2010.

Chan Miller, C., Gonzalez Abad, G., Wang, H., Liu, X., Kurosu, T., Jacob, D. J., and Chance, K.: Glyoxal retrieval from the Ozone Monitoring Instrument, Atmos. Meas. Tech., 7, 38913907, https://doi.org/10.5194/amt-7-3891-2014, 2014.

Chan Miller, C., Jacob, D. J., González Abad, G., and Chance, K.: Hotspot of glyoxal over the Pearl River delta seen from the OMI satellite instrument: implications for emissions of aromatic hydrocarbons, Atmos. Chem. Phys., 16, 4631-4639, https://doi.org/10.5194/acp-16-4631-2016, 2016.

Chance, K.: OMI/Aura Bromine Monoxide (BrO) Total Column 1-orbit L2 Swath 13x24 km V003, Greenbelt, MD, USA, Goddard Earth Sciences Data and Information Services Center (GES DISC), https://doi.org/10.5067/Aura/OMI/DATA2006, 2007a.

Chance, K.: OMI/Aura Chlorine Dioxide (OClO) Total Column 1-orbit L2 Swath $13 \times 24$ km V003, Goddard Earth Sciences Data and Information Services Center (GES DISC), https://doi.org/10.5067/Aura/OMI/DATA2019, $2007 \mathrm{~b}$.

Chance, K.: OMI/Aura Formaldehyde (HCHO) Total Column 1-orbit L2 Swath 13×24 km V003, Goddard Earth Sciences Data and Information Services Center (GES DISC), https://doi.org/10.5067/Aura/OMI/DATA2015, 2007c.

Chance, K.: OMI/Aura Formaldehyde (HCHO) Total Column Daily L2 Global Gridded 0.25 degree x 0.25 degree V3, Goddard Earth Sciences Data and Information Services Center (GES DISC), https://doi.org/10.5067/Aura/OMI/DATA2016, 2014.

Chance, K. V., Burrows, J. P., and Schneider, W.: Retrieval and molecule sensitivity studies for the Global Ozone Monitoring Experiment and the SCanning Imaging Absorption spectroMeter for Atmospheric CHartographY, Proc. SPIE, 1491, 151-165, 1991.

Chandra, S., Ziemke, J. R., Duncan, B. N., Diehl, T. L., Livesey, N. J., and Froidevaux, L.: Effects of the 2006 El Niño on tropospheric ozone and carbon monoxide: implications for dynamics and biomass burning, Atmos. Chem. Phys., 9, 4239-4249, https://doi.org/10.5194/acp-9-4239-2009, 2009.

Chen, Z., Torres, O., McCormick, M., Smith, W., and Ahn, C.: Comparative study of aerosol and cloud detected by CALIPSO and OMI, Atmos. Environ., 51, 187-195, https://doi.org/10.1016/j.atmosenv.2012.01.024, 2012.

Chimot, J., Veefkind, J. P., Vlemmix, T., de Haan, J. F., Amiridis, V., Proestakis, E., Marinou, E., and Levelt, P. F.: An exploratory study on the aerosol height retrieval from OMI measurements of the $477 \mathrm{~nm} \mathrm{O}-\mathrm{O}_{2}$ spectral band using a 
neural network approach, Atmos. Meas. Tech., 10, 783-809, https://doi.org/10.5194/amt-10-783-2017, 2017.

China Daily: China to launch 40 carrier rockets for various space missions in 2018, China Daily, available at: http://www.chinadaily.com.cn/a/201801/04/ WS5a4da7b1a31008cf16da50b9.html (last access: 5 April 2018), 2018.

Chipperfield, M. P., Bekki, S., Dhomse, S., Harris, N. R. P., Hassler, B., Hossaini, R., Steinbrecht, W., Thiéblemont, R., and Weber, M.: Detecting recovery of the stratospheric ozone layer, Nature, 549, 211-218, https://doi.org/10.1038/nature23681, 2017.

Choi, S., Joiner, J., Choi, Y., Duncan, B. N., Vasilkov, A., Krotkov, N., and Bucsela, E.: First estimates of global free-tropospheric $\mathrm{NO}_{2}$ abundances derived using a cloud-slicing technique applied to satellite observations from the Aura Ozone Monitoring Instrument (OMI), Atmos. Chem. Phys., 14, 10565-10588, https://doi.org/10.5194/acp-14-10565-2014, 2014.

Clark, L. P., Millet, D. B., and Marshall, J. D.: National patterns in environmental injustice and inequality: Outdoor $\mathrm{NO}_{2}$ air pollution in the United States, PLOS ONE, 9, 1-8, https://doi.org/10.1371/journal.pone.0094431, 2014.

Coldewey-Egbers, M., Loyola, D. G., Koukouli, M., Balis, D., Lambert, J.-C., Verhoelst, T., Granville, J., van Roozendael, M., Lerot, C., Spurr, R., Frith, S. M., and Zehner, C.: The GOMEtype Total Ozone Essential Climate Variable (GTO-ECV) data record from the ESA Climate Change Initiative, Atmos. Meas. Tech., 8, 3923-3940, https://doi.org/10.5194/amt-8-3923-2015, 2015.

Cooper, O. R., Parrish, D. D., Ziemke, J. R., Balashov, N. V., Cupeiro, M., Galbally, I., Gilge, S., Horowitz, L., Jensen, N. R., Lamarque, J.-F., Naik, V., Oltmans, S. J., Schwab, J., Shindell, D. T., Thompson, A. M., Thouret, V., Wang, Y., and Zbinden, R. M.: Global distribution and trends of tropospheric ozone: An observation-based review, Elementa: Science of the Anthropocene, 2, 000029, https://doi.org/10.12952/journal.elementa.000029, 2014.

Crouse, D. L., Peters, P. A., Hystad, P., Brook. J. R., van Donkelaar, A., Martin, R. V., Villeneuve, P. J., Jerrett, M., Goldberg, M. S., Pope III, C. A., Brauer, M., Brook, R. D., Robichaud, A., Menard, R., and Burnett, R. T.: Ambient $\mathrm{PM}_{2.5}, \mathrm{O}_{3}$, and $\mathrm{NO}_{2}$ exposures and associations with mortality over 16 years of follow-up in the Canadian Census Health and Environment Cohort (CanCHEC), Environ. Health Persp., 123, 1180-1186; https://doi.org/10.1289/ehp.1409276, 2015.

Cuesta, J., Eremenko, M., Liu, X., Dufour, G., Cai, Z., Höpfner, M., von Clarmann, T., Sellitto, P., Foret, G., Gaubert, B., Beekmann, M., Orphal, J., Chance, K., Spurr, R., and Flaud, J.-M.: Satellite observation of lowermost tropospheric ozone by multispectral synergism of IASI thermal infrared and GOME-2 ultraviolet measurements over Europe, Atmos. Chem. Phys., 13, 9675-9693, https://doi.org/10.5194/acp-13-9675-2013, 2013.

Curci, G., Palmer, P. I., Kurosu, T. P., Chance, K., and Visconti, G.: Estimating European volatile organic compound emissions using satellite observations of formaldehyde from the Ozone Monitoring Instrument, Atmos. Chem. Phys., 10, 11501-11517, https://doi.org/10.5194/acp-10-11501-2010, 2010.

Curier, R. L., Kranenburg, R., Segers, A. J., Timmermans, R. M., and Schaap, M.: Synergistic use of OMI $\mathrm{NO}_{2}$ tropospheric columns and LOTOS-EUROS to evaluate the $\mathrm{NO}_{x}$ emis- sion trends across Europe, Remote Sens. Environ., 149, 58-69, https://doi.org/10.1016/j.rse.2014.03.032, 2014.

Dahutia, P., Pathak, B., and Bhuyan, P. K.: Aerosols characteristics, trends and their climatic implications over Northeast India and adjoining South Asia, Int. J. Climatol., 38, 1234-1256, https://doi.org/10.1002/joc.5240, 2017.

David, L. M. and Nair, P. R.: Tropospheric column $\mathrm{O}_{3}$ and $\mathrm{NO}_{2}$ over the Indian region observed by Ozone Monitoring Instrument (OMI): Seasonal changes and long-term trends, Atmos. Environ., 65, 25-39, https://doi.org/10.1016/j.atmosenv.2012.09.033, 2013.

de Foy, B., Krotkov, N. A., Bei, N., Herndon, S. C., Huey, L. G., Martínez, A.-P., Ruiz-Suárez, L. G., Wood, E. C., Zavala, M., and Molina, L. T.: Hit from both sides: tracking industrial and volcanic plumes in Mexico City with surface measurements and OMI $\mathrm{SO}_{2}$ retrievals during the MILAGRO field campaign, Atmos. Chem. Phys., 9, 9599-9617, https://doi.org/10.5194/acp-99599-2009, 2009.

de Foy, B., Wilkins, J., Liu, Z., Streets, D., and Duncan, B. N.: Model evaluation of methods for estimating surface emissions and chemical lifetimes from satellite data, Atmos. Environ., 98, 66-77, https://doi.org/10.1016/j.atmosenv.2014.08.051, 2014.

de Foy, B., Lu, Z., Streets, D. G., Lamsal, L. N., and Duncan, B. N.: Estimates of power plant $\mathrm{NO}_{x}$ emissions and lifetimes from $\mathrm{OMI} \mathrm{NO}_{2}$ satellite retrievals, Atmos. Environ., 116, 1-11, https://doi.org/10.1016/j.atmosenv.2015.05.056, 2015.

de Foy, B., Lu, Z., and Streets, D. G.: Impacts of control strategies, the great recession and weekday variations on $\mathrm{NO}_{2}$ columns above North American cities, Atmos. Environ. 138, 74-86, 2016a.

de Foy, B., Lu, Z., and Streets, D. G.: Satellite $\mathrm{NO}_{2}$ retrievals suggest China has exceeded its $\mathrm{NO}_{x}$ reduction goals from the twelfth five-year plan, Sci. Rep., 6, 35912, https://doi.org/10.1038/srep35912, 2016b.

de Graaf, M., Tilstra, L. G., Wang, P., and Stammes, P.: Retrieval of the aerosol direct radiative effect over clouds from spaceborne spectrometry, J. Geophys. Res., 117, D07207, https://doi.org/10.1029/2011JD017160, 2012.

de Graaf, M., Bellouin, N., Tilstra, L. G., Haywood, J., and Stammes, P.: Aerosol direct radiative effect of smoke over clouds over the southeast Atlantic Ocean from 2006 to 2009, Geophys. Res. Lett. 41, https://doi.org/10.1002/2014GL061103, 2014.

de Graaf, M., Sihler, H., Tilstra, L. G., and Stammes, P.: How big is an OMI pixel?, Atmos. Meas. Tech., 9, 3607-3618, https://doi.org/10.5194/amt-9-3607-2016, 2016.

de Haan, J. and Veefkind, P.: OMI/Aura Ozone (O3) Profile 1-Orbit L2 Swath 13x48km V003, Goddard Earth Sciences Data and Information Services Center (GES DISC), https://doi.org/10.5067/Aura/OMI/DATA2026, 2009.

de Haan, J.: TROPOMI Algorithm theoretical basis document: Ozone profile and tropospheric profile, Tech. Rep., KNMI, S5PKNMI-L2-0004-RP, 2015.

de Haij, M., Wauben, W., and Klein Baltink, H.: Continuous mixing layer height determination using the LD-40 ceilometer: a feasibility study, KNMI Scientific Report, WR 2007-01, 2007.

de Hoogh, K., Gulliver, J., van Donkelaar, A., Martin, R. V., Marshall, J. D., Bechle, M. J., Cesaroni, G., Pradas, M. C., Dedele, A.,Eeftens, M., Forsberg, B., Galassi, C., Heinrich, J., Hoffmann, B., Jacquemin, B., Katsouyanni, K., Ko- 
rek, M., Künzli, N., Lindley, S. J., Lepeule, J., Meleux, F., de Nazelle, A., Nieuwenhuijsen, M., Nystad, W., RaaschouNielsen, O., Peters, A., Peuch, V.-H., Rouil, L., OUdvardy, O., Slama, R., Stempfelet, M., Stephanou, E. G., Tsai, M. Y., YliTuomi, T., Weinmayr, G., Brunekreef, B., Vienneau, D., and Hoek, G.: Development of West-European $\mathrm{PM}_{2.5}$ and $\mathrm{NO}_{2}$ land use regression models incorporating satellite-derived and chemical transport modelling data, Environ. Res., 151, 1-10, https://doi.org/10.1016/j.envres.2016.07.005, 2016.

de Laat, A. T. J., van der A, R. J., Allaart, M. A. F., van Weele, M., Benitez, G. C., Casiccia, C., Paes Leme, N. M., Quel, E., Salvador, J., and Wolfram, E.: Extreme sunbathing: Three weeks of small total $\mathrm{O}_{3}$ columns and high UV radiation over the southern tip of South America during the 2009 Antarctic $\mathrm{O}_{3}$ hole season, Geophys. Res. Lett., 37, L14805, https://doi.org/10.1029/2010GL043699, 2010.

de Laat, A. T. J., van der A, R. J., and van Weele, M.: Tracing the second stage of ozone recovery in the Antarctic ozone-hole with a "big data" approach to multivariate regressions, Atmos. Chem. Phys., 15, 79-97, https://doi.org/10.5194/acp-15-79-2015, 2015.

de Laat, A. T. J., van Weele, M., and van der A, R. J.: Onset of stratospheric ozone recovery in the Antarctic ozone hole in assimilated daily total ozone columns, J. Geophys. Res.-Atmos., 122, 11880-11899, https://doi.org/10.1002/2016JD025723, 2017.

DeLand, M. T. and Cebula, R. P.: Creation of a composite solar ultraviolet spectral irradiance data set, J. Geophys. Res., 113, A11103, https://doi.org/10.1029/2008JA013401, 2008.

DeLand, M. T. and Cebula, R. P.: Solar UV variations during the decline of Cycle 23, J. Atmos. Sol.-Terr. Phy., 77, 225-234, https://doi.org/10.1016/j.jastp.2012.01.007, 2012.

DeLand, M. T. and Marchenko, S.: The solar chromospheric Ca and Mg indices from Aura OMI, J. Geophys. Res., 118, 3415-3423, https://doi.org/10.1002/jgrd.50310, 2013.

DeLand, M. T., Shettle, E. P., Levelt, P. F., and Kowalewski, M. G.: Polar mesospheric clouds (PMCs) observed by the Ozone Monitoring Instrument (OMI) on Aura, J. Geophys. Res., 115, D21301, https://doi.org/10.1029/2009JD013685, 2010.

DeLand, M. T., Shettle, E. P., Thomas, G. E., and Olivero, J. J.: Direct observations of PMC local time variations by Aura OMI, J. Atmos. Sol.-Terr. Phy., 73, 2049-2064, https://doi.org/10.1016/j.jastp.2010.11.019, 2011.

De Smedt, I., Stavrakou, T., Hendrick, F., Danckaert, T., Vlemmix, T., Pinardi, G., Theys, N., Lerot, C., Gielen, C., Vigouroux, C., Hermans, C., Fayt, C., Veefkind, P., Müller, J.-F., and Van Roozendael, M.: Diurnal, seasonal and long-term variations of global formaldehyde columns inferred from combined OMI and GOME-2 observations, Atmos. Chem. Phys., 15, 12519-12545, https://doi.org/10.5194/acp-15-12519-2015, 2015.

DiGangi, J. P., Henry, S. B., Kammrath, A., Boyle, E. S., Kaser, L., Schnitzhofer, R., Graus, M., Turnipseed, A., Park, J.-H., Weber, R. J., Hornbrook, R. S., Cantrell, C. A., Maudlin III, R. L., Kim, S., Nakashima, Y., Wolfe, G. M., Kajii, Y., Apel, E. C., Goldstein, A. H., Guenther, A., Karl, T., Hansel, A., and Keutsch, F. N.: Observations of glyoxal and formaldehyde as metrics for the anthropogenic impact on rural photochemistry, Atmos. Chem. Phys., 12, 9529-9543, https://doi.org/10.5194/acp-129529-2012, 2012.

Ding, J., van der A, R. J., Mijling, B., Levelt, P. F., and Hao, N.: $\mathrm{NO}_{x}$ emission estimates during the 2014 Youth Olympic
Games in Nanjing, Atmos. Chem. Phys., 15, 9399-9412, https://doi.org/10.5194/acp-15-9399-2015, 2015.

Ding, J., van der A, R. J., Mijling, B., and Levelt, P. F.: Space-based $\mathrm{NO}_{x}$ emission estimates over remote regions improved in DECSO, Atmos. Meas. Tech., 10, 925-938, https://doi.org/10.5194/amt-10-925-2017, 2017a.

Ding, J., Miyazaki, K., van der A, R. J., Mijling, B., Kurokawa, J.-I., Cho, S., Janssens-Maenhout, G., Zhang, Q., Liu, F., and Levelt, P. F.: Intercomparison of $\mathrm{NO}_{x}$ emission inventories over East Asia, Atmos. Chem. Phys., 17, 10125-10141, https://doi.org/10.5194/acp-17-10125-2017, 2017b.

Dobber, M.: OMI/Aura Level 1B Solar Irradiances V003, Greenbelt, MD, USA, Goddard Earth Sciences Data and Information Services Center (GES DISC), https://doi.org/10.5067/Aura/OMI/DATA1001, 2007a.

Dobber, M.: OMI/Aura Level 1B UV Global Geolocated Earthshine Radiances 1-orbit L2 Swath 13x24 km V003, Greenbelt, MD, USA, Goddard Earth Sciences Data and Information Services Center (GES DISC), https://doi.org/10.5067/Aura/OMI/DATA1002, 2007b.

Dobber, M.: OMI/Aura Level 1B UV Zoom-in Geolocated Earthshine Radiances 1-orbit L2 Swath 13x12 km V003, Greenbelt, MD, USA, Goddard Earth Sciences Data and Information Services Center (GES DISC), https://doi.org/10.5067/Aura/OMI/DATA1003, 2007c.

Dobber, M.: OMI/Aura Level 1B VIS Global Geolocated Earth Shine Radiances 1-orbit L2 Swath 13x24 km V003, Greenbelt, MD, USA, Goddard Earth Sciences Data and Information Services Center (GES DISC), https://doi.org/10.5067/Aura/OMI/DATA1004, 2007d.

Dobber, M.: OMI/Aura Level 1B VIS Zoom-in Geolocated Earthshine Radiances 1-orbit L2 Swath 13x12 km V003, Greenbelt, MD, USA, Goddard Earth Sciences Data and Information Services Center (GES DISC), https://doi.org/10.5067/Aura/OMI/DATA1005, 2007e.

Dobber, M., Voors, R., Dirksen, R., Kleipool, Q., and Levelt, P.: The high-resolution solar reference spectrum between 250 and $550 \mathrm{~nm}$ and its application to measurements with the Ozone Monitoring Instrument, Sol. Phys., 249, 281-291, https://doi.org/10.1007/s11207-008-9187-7, 2008a.

Dobber, M., Kleipool, Q., Dirksen, R., Levelt, P., Jaross, G., Taylor, S., Kelly, T., and Flynn, L.: Validation of ozone monitoring instrument level-1b data products, J. Geophys. Res., 113, D15S06, https://doi.org/10.1029/2007JD008665, 2008b.

Dobber, M. R., Dirksen, R., Levelt, P., van den Oord, H. J., Voors, R., Kleipool, Q., Jaross, G., Kowalewski, M., Hilsenrath, E., Leppelmeier, G., de Vries, J., Dierssen W., and Rozemeijer N.: Ozone Monitoring Instrument calibration, IEEE T. Geosci. Remote, 44, 1209-1238, https://doi.org/10.1109/TGRS.2006.869987, 2006.

Donovan D. P. and Apituley, A.: Practical depolarization- ratiobased inversion procedure: lidar measurements of the Eyjafjallajökull ash cloud over the Netherlands, Appl. Opt., 52, 2394 2415, 2013.

Douglass, A., Fioletov, V., Godin-Beekmann, S., Müller, R., Stolarski, R. S., Webb, A., Arola, A., Burkholder, J. B., Burrows, J. P., Chipperfield, M. P., Cordero, R., David, C., den Outer, P. N., Diaz, S. B., Flynn, L. E., Hegglin, M., Herman, J. R., Huck, P., Janjai, S., Janosi, I. M., Kryscin, J. W., Liu, 
Y., Logan, J., Matthes, K., McKenzie, R. L., Muthama, N. J., Petropavlovskikh, I., Pitts, M., Ramachandran, S., Rex, M., Salawitch, R. J., Sinnhuber, B. M., Staehelin, J., Strahan, S., Tourpali, K., Valverde-Canossa, J., Vigouroux, C., Bodeker, G. E., Canty, T., De Backer, H., Demoulin, P., Feister, U., Frith, S. M., Grooß, J. U., Hase, F., Klyft, J., Koide, T., Kurylo, M. J., Loyola, D., McLinden, C. A., Megretskaia, I. A., Nair, P. J., Palm, M., Papanastasiou, D., Poole, L. R., Schneider, M., Schofield, R., Slaper, H., Steinbrecht, W., Tegtmeier, S., Terao, Y., Tilmes, S., Vyushin, D. I., Weber, M., and Yang, E. S.: Stratospheric Ozone and Surface Ultraviolet Radiation, in: Scientific Assessment of Ozone Depletion: 2010, Chapter 2, World Meteorological Organization, Geneva, Switzerland, 1-80, 2011.

Duncan, B., Yoshida, Y., Damon, M., Douglass, A., and Witte, J.: Temperature dependence of factors controlling isoprene emissions, Geophys. Res. Lett., L05813, https://doi.org/10.1029/2008GL037090, 2009.

Duncan, B., Yoshida, Y., Olson, J., Sillman, S., Martin, R., Lamsal, L., Hu, Y., Pickering, K. Retscher, D. Allen, D., and Crawford, J.: Application of OMI observations to a space-based indicator of $\mathrm{NO}_{x}$ and VOC controls on surface ozone formation, Atmos. Environ., 44, 2213-2223, https://doi.org/10.1016/j.atmosenv.2010.03.010, 2010.

Duncan, B., Yoshida, Y., de Foy, B., Lamsal, L., Streets, D., Lu, Z., Pickering, K., and Krotkov, N.: The observed response of Ozone Monitoring Instrument (OMI) $\mathrm{NO}_{2}$ columns to $\mathrm{NO}_{x}$ emission controls on power plants in the United States: 2005-2011, Atmos. Environ., 81, 102-111, https://doi.org/10.1016/j.atmosenv.2013.08.068, 2013.

Duncan, B., Prados, A. I., Lamsal, L. N., Liu, Y., Streets, D. G., Gupta, P., Hilsenrath, E., Kahn, R. A., Nielsen, J. E., Beyersdorf, A. J., Burton, S. P., Fiore, A. M., Fishman, J., Henze, D. K., Hostetler, C. A., Krotkov, N. A., Lee, P., Lin, M., Pawson, S., Pfister, G., Pickering, K. E., Pierce, R. B., Yoshida, Y., and Ziemba, L. D.: Satellite Data of Atmospheric Pollution for U.S. Air Quality Applications: Examples of Applications, Summary of Data End-User Resources, Answers to FAQs, and Common Mistakes to Avoid, Atmos. Environ., 94, 647-662, https://doi.org/10.1016/j.atmosenv.2014.05.061, 2014.

Duncan, B. N., Lamsal, L. N., Thompson, A. M., Yoshida, Y., Lu, Z., Streets, D. G., Hurwitz, M. M., and Pickering, K. E.: A spacebased, high-resolution view of notable changes in urban $\mathrm{NO}_{x}$ pollution around the world (2005-2014), J. Geophys. Res., 121, 976-996, https://doi.org/10.1002/2015JD024121, 2016.

Eck, T. F., Bhartia P. K., and Kerr J. B.: Satellite Estimation of Spectral UVB Irradiance Using TOMS Derived Total Ozone and UV Reflectivity, Geophys. Res. Lett., 22, 611-614, 1995.

Eisinger, M. and Burrows, J. P.: Tropospheric sulfur dioxide observed by the ERS-2 GOME instrument, Geophys. Res. Lett. 25, 4177-4180, 1998.

Eldering, A., Wennberg, P. O., Crisp, D., Schimel, D. S., Gunson, M. R., Chatterjee, A., Liu, J., Schwandner, F. M., Sun, Y., O’Dell, C. W., Frankenberg, C., Taylor, T., Fisher, B., Osterman, G. B., Wunch, D., Hakkarainen, J., Tamminen, J., and Weir, B.: The Orbiting Carbon Observatory-2 early science investigations of regional carbon dioxide fluxes, Science, 358, eaam5745, https://doi.org/10.1126/science.aam5745, 2017.

Ermolli, I., Matthes, K., Dudok de Wit, T., Krivova, N. A., Tourpali, K., Weber, M., Unruh, Y. C., Gray, L., Langematz, U., Pilewskie,
P., Rozanov, E., Schmutz, W., Shapiro, A., Solanki, S. K., and Woods, T. N.: Recent variability of the solar spectral irradiance and its impact on climate modelling, Atmos. Chem. Phys., 13, 3945-3977, https://doi.org/10.5194/acp-13-3945-2013, 2013.

Eskes, H., Huijnen, V., Arola, A., Benedictow, A., Blechschmidt, A.-M., Botek, E., Boucher, O., Bouarar, I., Chabrillat, S., Cuevas, E., Engelen, R., Flentje, H., Gaudel, A., Griesfeller, J., Jones, L., Kapsomenakis, J., Katragkou, E., Kinne, S., Langerock, B., Razinger, M., Richter, A., Schultz, M., Schulz, M., Sudarchikova, N., Thouret, V., Vrekoussis, M., Wagner, A., and Zerefos, C.: Validation of reactive gases and aerosols in the MACC global analysis and forecast system, Geosci. Model Dev., 8, 3523-3543, https://doi.org/10.5194/gmd-8-3523-2015, 2015.

Eyring, V., Cionni, I., Bodeker, G. E., Charlton-Perez, A. J., Kinnison, D. E., Scinocca, J. F., Waugh, D. W., Akiyoshi, H., Bekki, S., Chipperfield, M. P., Dameris, M., Dhomse, S., Frith, S. M., Garny, H., Gettelman, A., Kubin, A., Langematz, U., Mancini, E., Marchand, M., Nakamura, T., Oman, L. D., Pawson, S., Pitari, G., Plummer, D. A., Rozanov, E., Shepherd, T. G., Shibata, K., Tian, W., Braesicke, P., Hardiman, S. C., Lamarque, J. F., Morgenstern, O., Pyle, J. A., Smale, D., and Yamashita, Y.: Multimodel assessment of stratospheric ozone return dates and ozone recovery in CCMVal-2 models, Atmos. Chem. Phys., 10, 94519472, https://doi.org/10.5194/acp-10-9451-2010, 2010.

Ferguson, D. J., Barnie, T. D., Pyle, D. M., Oppenheimer, C., Yirgu, G., Lewi, E., Kidane, T., Carn, S. A., and Hamling, I.: Recent riftrelated volcanism in Afar, Ethiopia, Earth Planet. Sc. Lett., 292, 409-418, https://doi.org/10.1016/j.eps1.2010.02.010, 2010.

Fishman, J., Creilson, J. K., Parker, P. A., Ainsworth, E. A., Vining, G. G., Szarka, J., Booker, F. L., and Xu, X.: An investigation of widespread ozone damage to the soybean crop in the upper Midwest determined from ground-based and satellite measurements, Atmos. Environ., 44, 2248-2256, https://doi.org/10.1016/j.atmosenv.2010.01.015, 2010.

Fioletov, V. E., McLinden, C. A., Krotkov, N., Moran, M. D., and Yang, K.: Estimation of $\mathrm{SO}_{2}$ emissions using OMI retrievals, Geophys. Res. Lett., 38, L21811, https://doi.org/10.1029/2011GL049402, 2011.

Fioletov, V. E., McLinden, C. A., Krotkov, N., Yang, K., Loyola, D. G., Valks, P., Theys, N., Van Roozendael, M., Nowlan, C. R., Chance, K., Liu, X., Lee, C., and Martin, R. V.: Application of OMI, SCIAMACHY, and GOME-2 satellite $\mathrm{SO}_{2}$ retrievals for detection of large emission sources, J. Geophys. Res., 118, 11399-11418, https://doi.org/10.1002/jgrd.50826, 2013.

Fioletov, V. E., McLinden, C. A., Krotkov, N. A., and Li, C.: Lifetimes and emissions of $\mathrm{SO}_{2}$ from point sources estimated from OMI, Geophys. Res. Lett., 42, 1-8, https://doi.org/10.1002/2015GL063148, 2015.

Fioletov, V. E., McLinden, C. A., Krotkov, N., Li, C., Joiner, J., Theys, N., Carn, S., and Moran, M. D.: A global catalogue of large $\mathrm{SO}_{2}$ sources and emissions derived from the Ozone Monitoring Instrument, Atmos. Chem. Phys., 16, 11497-11519, https://doi.org/10.5194/acp-16-11497-2016, 2016.

Flower, V. J. B. and Carn, S. A.: Characterizing volcanic cycles at Soufriere Hills Volcano, Montserrat: time series analysis of multi-parameter satellite data, J. Volcanol. Geoth. Res., 304, 8293, https://doi.org/10.1016/j.jvolgeores.2015.07.035, 2015. 
Floyd, L. E., Herring, L. C., Prinz, D. K., and Crane, P. C.: Instrument responsivity evolution of SUSIM UARS, Proc. SPIE, 3427 , 445-456, 1998.

Flynn, C., Pickering, K. E., Crawford, J. H., Lamsal, L., Krotkov, N., Herman, J., Weinheimer, A., Chen, G., Liu, X., Szykman, J., Tsay, S.-C., Loughner, C. P., Hains, J., Lee, P., Dickerson, R. R., Stehr, J. W., and Brent, L.: The relationship between column-density and surface mixing ratio: statistical analysis of $\mathrm{O}_{3}$ and $\mathrm{NO}_{2}$ data from the July 2011 Maryland DISCOVER-AQ mission, Atmos. Environ., 92, 429-441, https://doi.org/10.1016/j.atmosenv.2014.04.041, 2014.

Flynn, L., Long, C., Wu, X., Evans, R., Beck, C. T., Petropavlovskikh, I., McConville, G., Yu, W., Zhang, Z., Niu, J., Beach, E., Hao, Y., Pan, C., Sen, B., Novicki, M., Zhou, S., and Seftor, C.: Performance of the Ozone Mapping and Profiler Suite (OMPS) products, J. Geophys. Res., 119, 6181-6195, https://doi.org/10.1002/2013JD020467, 2014.

Foret, G., Eremenko, M., Cuesta, J., Sellitto, P., Barré, J., Gaubert, B., Coman, A., Dufour, G., Liu, X., Joly, M., and Beekmann, M.: Ozone pollution: What can we see from space? A case study, J. Geophys. Res., 119, 8476-8499, https://doi.org/10.1002/2013JD021340, 2014.

Frith, S. M., Kramarova, N. A., Stolarski, R. S., McPeters, R. D., Bhartia, P. K., and Labow, G. J.: Recent changes in total column ozone based on the SBUV Version 8.6 merged ozone data set, J. Geophys. Res., 119, 9735-9751, https://doi.org/10.1002/2014JD021889, 2014.

Fu, D., Worden, J. R., Liu, X., Kulawik, S. S., Bowman, K. W., and Natraj, V.: Characterization of ozone profiles derived from Aura TES and OMI radiances, Atmos. Chem. Phys., 13, 3445-3462, https://doi.org/10.5194/acp-13-3445-2013, 2013.

Fu, D., Bowman, K. W., Worden, H. M., Natraj, V., Worden, J. R., Yu, S., Veefkind, P., Aben, I., Landgraf, J., Strow, L., and Han, Y.: High-resolution tropospheric carbon monoxide profiles retrieved from CrIS and TROPOMI, Atmos. Meas. Tech., 9, 2567-2579, https://doi.org/10.5194/amt-9-2567-2016, 2016.

Fu, D., Kulawik, S. S., Miyazaki, K., Bowman, K. W., Worden, J. R., Eldering, A., Livesey, N. J., Teixeira, J., Irion F. W., Herman, R. L., Osterman, G. B., Liu, X., Levelt, P., Thompson, A. M., Strow, L. L., and Luo, M.: Retrievals of Tropospheric Ozone Profiles from the Synergic Observation of AIRS and OMI: Methodology and Validation, Atmos. Meas. Tech. Discuss., submitted, 2018

Gassó, S. and Torres, O.: The role of cloud contamination, aerosol layer height and aerosol model in the assessment of the OMI near-UV retrievals over the ocean, Atmos. Meas. Tech., 9, 30313052, https://doi.org/10.5194/amt-9-3031-2016, 2016.

Gelaro, R., McCarty, W., Suárez, M. J., Todling, R., Molod, A., Takacs, L., Randles, C. A., Darmenov, A., Bosilovich, M. G., Reichle, R., Wargan, K., Coy, L., Cullather, R., Draper, C., Akella, S., Buchard, V., Conaty, A., da Silva, A. M., Gu, W., Kim, G., Koster, R., Lucchesi, R., Merkova, D., Nielsen, J. E., Partyka, G., Pawson, S., Putman, W., Rienecker, M., Schubert, S. D., Sienkiewicz, M., and Zhao, B.: The Modern-Era Retrospective Analysis for Research and Applications, Version 2 (MERRA-2), J. Climate, 30, 5419-5454, https://doi.org/10.1175/JCLI-D-160758.1, 2017.

Ghosh, D., Lal, S., and Sarkar, U.: Variability of tropospheric columnar $\mathrm{NO}_{2}$ and $\mathrm{SO}_{2}$ over eastern Indo-Gangetic Plain and impact of meteorology, Air Qual. Atmos. Hlth., 10, 565-574, 2017.

Ghude, S. D., Pfister, G. G., Jena, C., van der A, R. J., Emmons, L. K., and Kumar, R.: Satellite constraints of nitrogen oxide $\left(\mathrm{NO}_{x}\right)$ emissions from India based on OMI observations and WRF-Chem simulations, Geophys. Res. Lett., 40, 423-428, https://doi.org/10.1029/2012GL053926, 2013.

Goitom, B., Oppenheimer, C., Hammond, J., Grandin, R., Barnie, T., Donovan, A., Ogubazghi, G., Yohannes, E., Kibrom, G., Kendall, M., Carn, S. A., Fee, D., Sealing, C., Blundy, J., Hamlyn, J., Keir, D., Ayele, A., Wright, T., and Berhe, S.: First recorded eruption of Nabro volcano, Eritrea, 2011, B. Volcanol., 77, 85, https://doi.org/10.1007/s00445-015-0966-3, 2015.

González Abad, G., Liu, X., Chance, K., Wang, H., Kurosu, T. P., and Suleiman, R.: Updated Smithsonian Astrophysical Observatory Ozone Monitoring Instrument (SAO OMI) formaldehyde retrieval, Atmos. Meas. Tech., 8, 19-32, https://doi.org/10.5194/amt-8-19-2015, 2015.

Gupta, P., Joiner, J., Vasilkov, A., and Bhartia, P. K.: Top-of-theatmosphere shortwave flux estimation from satellite observations: an empirical neural network approach applied with data from the A-train constellation, Atmos. Meas. Tech., 9, 28132826, https://doi.org/10.5194/amt-9-2813-2016, 2016.

Hache, E., Attié, J.-L., Tourneur, C., Ricaud, P., Coret, L., Lahoz, W. A., El Amraoui, L., Josse, B., Hamer, P., Warner, J., Liu, X., Chance, K., Höpfner, M., Spurr, R., Natraj, V., Kulawik, S., Eldering, A., and Orphal, J.: The added value of a visible channel to a geostationary thermal infrared instrument to monitor ozone for air quality, Atmos. Meas. Tech., 7, 2185-2201, https://doi.org/10.5194/amt-7-2185-2014, 2014.

Haigh, J. D., Winning, A. R., Toumi, R., and Harder, J. W.: An influence of solar spectral variations on radiative forcing of climate, Nature, 467, 696-699, https://doi.org/10.1038/nature09426, 2010.

Hains, J. C., Boersma, K. F., Kroon, M., Dirksen, R., Cohen, R. C., Perring, A., Bucsela, E., Volten, H., Swart, D., Richter, A., Wittrock, F., Schoenhardt, A., Wagner, T., Ibrahim, O., Van Roozendael, M., Pinardi, G., Gleason, J. F., Veefkind, J., and Levelt, P. F.: Testing and Improving OMI DOMINO Tropospheric $\mathrm{NO}_{2}$ Using Observations from the DANDELIONS and INTEX-B Validation Campaigns, J. Geophys. Res., 115, D05301, https://doi.org/10.1029/2009JD012399, 2010.

Hakkarainen, J., Ialongo, I., and Tamminen, J.: Direct spacebased observations of anthropogenic $\mathrm{CO}_{2}$ emission areas from OCO-2, Geophys. Res. Lett., 43, 11400-11406, https://doi.org/10.1002/2016GL070885, 2016.

Haley, C. S. and Brohede, S.: Status of the Odin/OSIRIS stratospheric $\mathrm{O}_{3}$ and $\mathrm{NO}_{2}$ data products, Can. J. Phys., 85, 1177-1194, https://doi.org/10.1139/P07-114, 2007.

Hammer, M. S., Martin, R. V., van Donkelaar, A., Buchard, V., Torres, O., Ridley, D. A., and Spurr, R. J. D.: Interpreting the ultraviolet aerosol index observed with the OMI satellite instrument to understand absorption by organic aerosols: implications for atmospheric oxidation and direct radiative effects, Atmos. Chem. Phys., 16, 2507-2523, https://doi.org/10.5194/acp16-2507-2016, 2016.

Han, X., Zhang, M., Skorokhod, A., and Kou, X.: Modeling dry deposition of reactive nitrogen in China with RAMS-CMAQ, Atmos. Environ., 166, 47-61, 2017. 
Harder, J. W., Fontenla, J. M., Pilewskie, P., Richard, E. C., and Woods, T. N.: Trends in solar spectral irradiance variability in the visible and infrared, Geophys. Res. Lett., 36, L07801, https://doi.org/10.1029/2008GL036797, 2009.

Hassinen, S., Tamminen, J., Tanskanen, A., Leppelmeier, G., Mälkki, A., Koskela, T., Karhu, J. M., Lakkala, K., Veefkind, P., Krotkov, N., and Aulamo, O.: Description and validation of the OMI very fast delivery products, J. Geophys. Res., 2, D16S35, https://doi.org/10.1029/2007JD008784, 2008.

Hayashida, S., Liu, X., Ono, A., Yang, K., and Chance, K.: Observation of ozone enhancement in the lower troposphere over East Asia from a space-borne ultraviolet spectrometer, Atmos. Chem. Phys., 15, 9865-9881, https://doi.org/10.5194/acp-159865-2015, 2015.

Hayashida, S., Kayaba, S., Deushi, M., Yamaji, K., Ono, A., Kajino, M., Sekiyama, T. T., Maki, T., and Liu, X.: Study on lower tropospheric ozone over central and eastern China: Comparison of satellite observation with model simulation, Springer in LandAtmospheric Interactions in Asia, 2016.

Heath, D. F., Krueger, A. J., Roeder, H. R., and Henderson, B.D.: The solar backscatter ultraviolet and total ozone mapping spectrometer (SBUV/TOMS) for Nimbus G, Opt. Eng., 14, 323-331, 1975.

Herman, J., Cede, A., Spinei, E., Mount, G., Tzortziou, M., and Abuhassan, N.: $\mathrm{NO}_{2}$ column amounts from groundbased Pandora and MFDOAS spectrometers using the direct-sun DOAS technique: Intercomparisons and application to OMI validation, J. Geophys. Res., 114, D13307, https://doi.org/10.1029/2009JD011848, 2009.

Herron-Thorpe, F. L., Lamb, B. K., Mount, G. H., and Vaughan, J. K.: Evaluation of a regional air quality forecast model for tropospheric $\mathrm{NO}_{2}$ columns using the OMI/Aura satellite tropospheric $\mathrm{NO}_{2}$ product, Atmos. Chem. Phys., 10, 8839-8854, https://doi.org/10.5194/acp-10-8839-2010, 2010.

Hoek, G., Eeftens, M., Beelen, R., Fischer, P., Brunekreef, B., Boersma, K. F., and Veefkind, J. P.: Satellite $\mathrm{NO}_{2}$ data improve national land use regression models for ambient $\mathrm{NO}_{2}$ in a small densely populated country, Atmos. Environ., 105, 173180, https://doi.org/10.1016/j.atmosenv.2015.01.053, 2015.

Hoff, R. and Christopher, S. A.: Remote sensing of particulate matter air pollution from space: Have we reached the promised land?, J. Air Waste Manage., 59, 642-675, https://doi.org/10.3155/1047-3289.59.6.642, 2009.

Hönninger, G., von Friedeburg, C., and Platt, U.: Multi axis differential optical absorption spectroscopy (MAX-DOAS), Atmos. Chem. Phys., 4, 231-254, https://doi.org/10.5194/acp-4231-2004, 2004.

Hovila, J., Arola, A., and Tamminen, J.: OMI/Aura Surface UV Irradiance 1-orbit L2 Swath 13x24 km V003, Greenbelt, MD, USA, Goddard Earth Sciences Data and Information Services Center (GES DISC), https://doi.org/10.5067/Aura/OMI/DATA2027, 2007.

Hovila, J., Arola, A., and Tamminen, J.: OMI/Aura Surface UVB Irradiance and Erythemal Dose Daily L3 Global Gridded 1.0 degree x 1.0 degree V3, Goddard Earth Sciences Data and Information Services Center (GES DISC), https://doi.org/10.5067/Aura/OMI/DATA3009, 2013.

Hovila, J., Arola, A., and Tamminen, J.: OMI/Aura Surface UVB Irradiance and Erythemal Dose Daily L2 Global Grid- ded 0.25 degree x 0.25 degree V3, Goddard Earth Sciences Data and Information Services Center (GES DISC), https://doi.org/10.5067/Aura/OMI/DATA2028, 2014.

Hsu, N. C., Li, C., Krotkov, N. A., Liang, Q., Yang, K., and Tsay, S.-C.: Rapid transpacific transport in autumn observed by the A-train satellites, J. Geophys. Res., 117, D06312, https://doi.org/10.1029/2011JD016626, 2012.

Huang, G., Liu, X., Chance, K., Yang, K., Bhartia, P. K., Cai, Z., Allaart, M., Ancellet, G., Calpini, B., Coetzee, G. J. R., CuevasAgulló, E., Cupeiro, M., De Backer, H., Dubey, M. K., Fuelberg, H. E., Fujiwara, M., Godin-Beekmann, S., Hall, T. J., Johnson, B., Joseph, E., Kivi, R., Kois, B., Komala, N., König-Langlo, G., Laneve, G., Leblanc, T., Marchand, M., Minschwaner, K. R., Morris, G., Newchurch, M. J., Ogino, S.-Y., Ohkawara, N., Piters, A. J. M., Posny, F., Querel, R., Scheele, R., Schmidlin, F. J., Schnell, R. C., Schrems, O., Selkirk, H., Shiotani, M., Skrivánková, P., Stübi, R., Taha, G., Tarasick, D. W., Thompson, A. M., Thouret, V., Tully, M. B., Van Malderen, R., Vömel, H., von der Gathen, P., Witte, J. C., and Yela, M.: Validation of 10-year SAO OMI Ozone Profile (PROFOZ) product using ozonesonde observations, Atmos. Meas. Tech., 10, 2455-2475, https://doi.org/10.5194/amt-10-2455-2017, 2017.

Hystad, P. W., Setton, E., Cervantes, A., Poplawski, K.. Deschenes, S., Brauer, M., van Donkelaar, A., Lamsal, L. N., Martin, R. V., Jerrett, M., and Demers, P. A.: Creating National Air Pollution Models for Population Exposure Assessment in Canada, Environ. Health Persp., 119, 1123-1129, https://doi.org/10.1289/ehp.1002976, 2011.

Hystad, P. W., Demers, P. A., Johnson, K.C., Brook, J. R., van Donkelaar, A., Lamsal, L. N., Martin, R. V., and Brauer, M.: Spatiotemporal air pollution exposure assessment for a Canadian population-based lung cancer case-control study, Environ. Health, 11, 22, https://doi.org/10.1186/1476-069X-11-22, 2012.

Ialongo, I., Hakkarainen, J., Kivi, R., Anttila, P., Krotkov, N. A., Yang, K., Li, C., Tukiainen, S., Hassinen, S., and Tamminen, J.: Comparison of operational satellite $\mathrm{SO}_{2}$ products with groundbased observations in northern Finland during the Icelandic Holuhraun fissure eruption, Atmos. Meas. Tech., 8, 2279-2289, https://doi.org/10.5194/amt-8-2279-2015, 2015.

Ialongo, I., Herman, J., Krotkov, N., Lamsal, L., Boersma, K. F., Hovila, J., and Tamminen, J.: Comparison of OMI $\mathrm{NO}_{2}$ observations and their seasonal and weekly cycles with ground-based measurements in Helsinki, Atmos. Meas. Tech., 9, 5203-5212, https://doi.org/10.5194/amt-9-5203-2016, 2016.

Ingmann, P., Veihelmann, B., Langen, J., Lamarre, D., Stark, H., and Courrèges-Lacoste, G. B.: Requirements for the GMES Atmosphere Service and ESA's implementation concept: Sentinels-4/-5 and -5p, Remote Sens. Environ., 120, 58-69, https://doi.org/10.1016/j.rse.2012.01.023, 2012.

Inness, A., Baier, F., Benedetti, A., Bouarar, I., Chabrillat, S., Clark, H., Clerbaux, C., Coheur, P., Engelen, R. J., Errera, Q., Flemming, J., George, M., Granier, C., Hadji-Lazaro, J., Huijnen, V., Hurtmans, D., Jones, L., Kaiser, J. W., Kapsomenakis, J., Lefever, K., Leitão, J., Razinger, M., Richter, A., Schultz, M. G., Simmons, A. J., Suttie, M., Stein, O., Thépaut, J.-N., Thouret, V., Vrekoussis, M., Zerefos, C., and the MACC team: The MACC reanalysis: an $8 \mathrm{yr}$ data set of atmospheric composition, Atmos. Chem. Phys., 13, 4073-4109, https://doi.org/10.5194/acp13-4073-2013, 2013. 
Inness, A., Blechschmidt, A.-M., Bouarar, I., Chabrillat, S., Crepulja, M., Engelen, R. J., Eskes, H., Flemming, J., Gaudel, A., Hendrick, F., Huijnen, V., Jones, L., Kapsomenakis, J., Katragkou, E., Keppens, A., Langerock, B., de Mazière, M., Melas, D., Parrington, M., Peuch, V. H., Razinger, M., Richter, A., Schultz, M. G., Suttie, M., Thouret, V., Vrekoussis, M., Wagner, A., and Zerefos, C.: Data assimilation of satelliteretrieved ozone, carbon monoxide and nitrogen dioxide with ECMWF's Composition-IFS, Atmos. Chem. Phys., 15, 52755303, https://doi.org/10.5194/acp-15-5275-2015, 2015.

Irie, H., Boersma, K. F., Kanaya, Y., Takashima, H., Pan, X., and Wang, Z. F.: Quantitative bias estimates for tropospheric $\mathrm{NO}_{2}$ columns retrieved from SCIAMACHY, OMI, and GOME-2 using a common standard for East Asia, Atmos. Meas. Tech., 5, 2403-2411, https://doi.org/10.5194/amt-5-2403-2012, 2012.

Jethva, H., Torres, O., and Ahn, C.: Global assessment of OMI aerosol single-scattering albedo using ground-based AERONET inversion, J. Geophys. Res., 119, 9020-9040, https://doi.org/10.1002/2014JD021672, 2014a.

Jethva, H. T., Torres, O., Waquet, F., Chand, D., and Hu, Y.: How do A-train sensors intercompare in the retrieval of above-cloud aerosol optical depth? A case study-based assessment, Geophys. Res. Lett., 41, 186-192, https://doi.org/10.1002/2013GL058405, 2014b.

Jethva, H., Torres, O., and Ahn, C.: A ten-year global record of absorbing aerosols above clouds from OMI's near-UV observations, SPIE Asia-Pacific Remote Sensing Symposium, Remote Sensing of the Atmosphere, Clouds, and Precipitation VI, https://doi.org/10.1117/12.2225765, 2016.

Jin, X. and Holloway, T.: Spatial and temporal variability of ozone sensitivity over China observed from the Ozone Monitoring Instrument, J. Geophys. Res., 120, 7229-7246, https://doi.org/10.1002/2015JD023250, 2015.

Jing, P., Cunnold, D., Choi, Y., and Wang, Y.: Summertime tropospheric ozone columns from Aura OMI/MLS measurements versus regional model results over the United States, Geophys. Res. Lett., 33, L17817, https://doi.org/10.1029/2006GL026473, 2006.

Joiner, J.: OMI/Aura Cloud Pressure and Fraction (Raman Scattering) 1-Orbit L2 Swath 13x24 km V003, Greenbelt, MD, USA, Goddard Earth Sciences Data and Information Services Center (GES DISC), https://doi.org/10.5067/Aura/OMI/DATA2010, 2006.

Joiner, J.: OMI/Aura Effective Cloud Pressure and Fraction (Raman Scattering) Daily L2 Global Gridded 0.25 degree $\mathrm{x}$ 0.25 degree V3, Greenbelt, MD, USA, Goddard Earth Sciences Data and Information Services Center (GES DISC), https://doi.org/10.5067/Aura/OMI/DATA2011, 2012.

Joiner, J.: OMI/Aura and MODIS/Aqua Merged Cloud Product 1-Orbit L2 Swath 13x24 km V003, Greenbelt, MD, USA, Goddard Earth Sciences Data and Information Services Center (GES DISC), https://disc.sci.gsfc.nasa.gov/datacollection/ OMMYDCLD_003.html, 2014.

Joiner, J.: OMI/Aura and MODIS/Aqua Merged Aerosol Geocolocation Product 1-Orbit L2 Swath 13x24 km V003, Greenbelt, MD, USA, Goddard Earth Sciences Data and Information Services Center (GES DISC), https://disc.sci.gsfc.nasa.gov/ datacollection/OMMYDAGEO_003.html, 2017.
Joiner, J. and Vasilkov, A.: First Results from the OMI Rotational Raman Scattering Cloud Pressure Algorithm, IEEE T. Geosci. Remote, 44, 1272-1282, 2006.

Joiner, J., Vasilkov, A. P., Yang, K., and Bhartia, P. K.: Observations over hurricanes from the ozone monitoring instrument, Geophys. Res. Lett., 33, L06807, https://doi.org/10.1029/2005GL025592, 2006.

Joiner, J., Vasilkov, A. P., Bhartia, P. K., Wind, G., Platnick, S., and Menzel, W. P.: Detection of multi-layer and vertically-extended clouds using A-train sensors, Atmos. Meas. Tech., 3, 233-247, https://doi.org/10.5194/amt-3-233-2010, 2010.

Joiner, J., Vasilkov, A. P., Gupta, P., Bhartia, P. K., Veefkind, P., Sneep, M., de Haan, J., Polonsky, I., and Spurr, R.: Fast simulators for satellite cloud optical centroid pressure retrievals; evaluation of OMI cloud retrievals, Atmos. Meas. Tech., 5, 529-545, https://doi.org/10.5194/amt-5-529-2012, 2012.

Kar, J., Fishman, J., Creilson, J. K., Richter, A., Ziemke, J., and Chandra, S.: Are there urban signatures in the tropospheric ozone column products derived from satellite measurements?, Atmos. Chem. Phys., 10, 5213-5222, https://doi.org/10.5194/acp-105213-2010, 2010.

Karpechko, A. Y., Backman, L., Thlix, L., Ialongo, I., Andersson, M., Fioletov, V., Heikkil, A., Johnsen, B., Koskela, T., Kyrl, E., Lakkala, K., Myhre, C. L., Rex, M., Sofieva, V. F., Tamminen, J., and Wohltmann, I.:. The link between springtime total ozone and summer UV radiation in Northern Hemisphere extratropics, J. Geophys. Res., 118, 8649-8661, 2013.

Kerminen, V.-M., Niemi, J. V., Timonen, H., Aurela, M., Frey, A., Carbone, S., Saarikoski, S., Teinilä, K., Hakkarainen, J., Tamminen, J., Vira, J., Prank, M., Sofiev, M., and Hillamo, R.: Characterization of a volcanic ash episode in southern Finland caused by the Grimsvötn eruption in Iceland in May 2011, Atmos. Chem. Phys., 11, 12227-12239, https://doi.org/10.5194/acp-11-122272011, 2011.

Kim, J.: GEMS (Geostationary Enviroment Monitoring Spectrometer) onboard the GeoKOMPSAT to monitor air quality in high temporal and spatial resolution over Asia- Pacific region, Abstract EGU2012-4051 presented at the 2012 EGU General Assembly, 2012.

Kim, P. S., Jacob, D. J., Liu, X., Warner, J. X., Yang, K., Chance, K., Thouret, V., and Nedelec, P.: Global ozone-CO correlations from OMI and AIRS: constraints on tropospheric ozone sources, Atmos. Chem. Phys., 13, 9321-9335, https://doi.org/10.5194/acp13-9321-2013, 2013.

Kinne, S., O’Donnel, D., Stier, P., Kloster, S., Zhang, K., Schmidt, H., Rast, S., Giorgetta, M., Eck, T. F., and Stevens, B.: MAC-v1: A new global aerosol climatology for climate studies, J. Adv. Model. Earth Syst., 5, 704-740, https://doi.org/10.1002/jame.20035, 2013.

Kleipool, Q.: OMI/Aura Surface Reflectance Climatology L3 Global Gridded 0.5 degree x 0.5 degree V3, Goddard Earth Sciences Data and Information Services Center (GES DISC), https://doi.org/10.5067/Aura/OMI/DATA3006, 2010.

Knepp, T., Pippin, M., Crawford, J., Chen, G., Szykman, J., Long, R., Cowen, L., Cede, A., Abuhassan, N., Herman, J., Delgado, R., Compton, J., Berkoff, T., Fishman, J., Martins, D., Stauffer, R., Thompson, A. M., Weinheimer, A., Knapp, D., Montzka, D., Lenschow, D., and Neil, D.: Estimating surface $\mathrm{NO}_{2}$ and $\mathrm{SO}_{2}$ mixing ratios from fastresponse total column observations and 
potential application to geostationary missions, J. Atmos. Chem., D15308, https://doi.org/10.1007/s10874-013-9257-6, 2013.

Knibbe, J. S., van der A, R. J., and de Laat, A. T. J.: Spatial regression analysis on 32 years of total column ozone data, Atmos. Chem. Phys., 14, 8461-8482, https://doi.org/10.5194/acp14-8461-2014, 2014.

Knibbs, L. D., Hewson, M. G., Bechle, M. J., Marshall, J. D., and Barnett, A. G.: A national satellite-based land-use regression model for air pollution exposure assessment in Australia, Environ. Res., 135, 204-211, https://doi.org/10.1016/j.envres.2014.09.011, 2014.

KNMI OMI: KNMI OMI website, available at: http://projects.knmi. nl/omi/research/calibration/instrument_status_v3/ last access: 10 April 2018.

Konovalov, I. B., Berezin, E. V., Ciais, P., Broquet, G., Zhuravlev, R. V., and Janssens-Maenhout, G.: Estimation of fossil-fuel $\mathrm{CO} 2$ emissions using satellite measurements of "proxy" species, Atmos. Chem. Phys., 16, 13509-13540, https://doi.org/10.5194/acp-16-13509-2016, 2016.

Kreher, K., Van Roozendael, M., Hendrick, F., Apituley, A., Friess, U., Lampel, J., Piters, A., Richter, A., Wagner, T., and CINDI2 Team: First results of the CINDI-2 semi-blind MAX-DOAS intercomparison, EGU General Assembly, Vienna, Austria, 2328 April 2017, EGU2017-13927, 2017.

Kroon, M., Veefkind, J. P., Sneep, M., McPeters, R. D., Bhartia, P. K., and Levelt, P. F.: Comparing OMI-TOMS and OMIDOAS total ozone column data, J. Geophys. Res., 113, D16S28, https://doi.org/10.1029/2007JD008798, 2008.

Kroon, M., de Haan, J. F., Veefkind, J. P., Froidevaux, L., Wang, R., Kivi, R., and Hakkarainen, J. J.: Validation of operational ozone profiles from the Ozone Monitoring Instrument, J. Geophys. Res., 116, D18305, https://doi.org/10.1029/2010JD015100, 2011

Krotkov, N. A., Bhartia, P. K., Herman, J. R., Fioletov, V., and Kerr, J.: Satellite estimation of spectral surface UV irradiance in the presence of tropospheric aerosols, J. Geophys. Res., 103, 87798793, 1998.

Krotkov, N. A., Bhartia, P. K., Herman, J. R., Ahmad, Z., and Fioletov, V.: Satellite estimation of spectral surface UV irradiance 2: effect of horizontally homogeneous clouds and snow, J. Geophys. Res., 106, 11743-11759, 2001.

Krotkov, N. A., Carn, S. A., Krueger, A. J., Bhartia, P. K., and Yang, K.: Band Residual Difference algorithm for retrieval of $\mathrm{SO}_{2}$ from the Aura Ozone Monitoring Instrument (OMI), IEEE T. Geosci. Remote, 44, 1259-1266, https://doi.org/10.1109/TGRS.2005.861932, 2006.

Krotkov, N. A., Schoeberl, M. R., Morris, G. A., Carn, S. A., and Yang, K.: Dispersion and lifetime of the $\mathrm{SO}_{2}$ cloud from the August 2008 Kasatochi eruption, J. Geophys. Res., 115, D00L20, https://doi.org/10.1029/2010JD013984, 2010.

Krotkov, N. A.: OMI/Aura NO2 Cloud-Screened Total and Tropospheric Column L3 Global Gridded 0.25 degree x 0.25 degree V3, NASA Goddard Space Flight Center, Goddard Earth Sciences Data and Information Services Center (GES DISC), https://doi.org/10.5067/Aura/OMI/DATA3007, 2013.

Krotkov, N. A., Li, C., Leonard, P.: OMI/Aura Sulfur Dioxide (SO2) Total Column L3 1 day Best Pixel in 0.25 degree x 0.25 degree V3, Greenbelt, MD, USA, Goddard Earth
Sciences Data and Information Services Center (GES DISC), https://doi.org/10.5067/Aura/OMI/DATA3008, 2015.

Krotkov, N. A., McLinden, C. A., Li, C., Lamsal, L. N., Celarier, E. A., Marchenko, S. V., Swartz, W. H., Bucsela, E. J., Joiner, J., Duncan, B. N., Boersma, K. F., Veefkind, J. P., Levelt, P. F., Fioletov, V. E., Dickerson, R. R., He, H., Lu, Z., and Streets, D. G.: Aura OMI observations of regional $\mathrm{SO}_{2}$ and $\mathrm{NO}_{2}$ pollution changes from 2005 to 2015, Atmos. Chem. Phys., 16, 46054629, https://doi.org/10.5194/acp-16-4605-2016, 2016.

Krotkov, N. A., Lamsal, L. N., Celarier, E. A., Swartz, W. H., Marchenko, S. V., Bucsela, E. J., Chan, K. L., Wenig, M., and Zara, M.: The version $3 \mathrm{OMI} \mathrm{NO}_{2}$ standard product, Atmos. Meas. Tech., 10, 3133-3149, https://doi.org/10.5194/amt10-3133-2017, 2017.

Krueger, A. J.: Sighting of El Chichon sulfur dioxide clouds with the Nimbus 7 total ozone mapping spectrometer, Science 220, 1377-1379, 1983.

Kurosu, T. P. and Celarier, E. A.: OMI/Aura Global Ground Pixel Corners 1-Orbit L2 Swath 13x24km V003, Greenbelt, MD, USA, Goddard Earth Sciences Data and Information Services Center (GES DISC), https://doi.org/10.5067/Aura/OMI/DATA2020, 2010a.

Kurosu, T. P. and Celarier, E. A.: OMI/Aura Zoomin Ground Pixel Corners 1-Orbit L2 Swath $13 \times 12 \mathrm{~km}$ V003, Greenbelt, MD, USA, Goddard Earth Sciences Data and Information Services Center (GES DISC), https://doi.org/10.5067/Aura/OMI/DATA2021, 2010 b.

Kushendratno, Pallister, J. S., Kristianto, Bina, F. R., McCausland, W., Carn, S. A., Haerani, N., Griswold, J., and Keeler, R. Recent explosive eruptions and volcano hazards at Soputan volcano - a basalt stratovolcano in north Sulawesi, Indonesia, B. Volcanol., 74, 1581-1609, 2012.

Labow, G., McPeters, R., Bhartia, P. K., and Kramarova, N.: A comparison of 40 years of SBUV measurements of column ozone with data from the Dobson/Brewer network, J. Geophys. Res., 118, 7370-7378, https://doi.org/10.1002/jgrd.50503, 2013.

Lacagnina, C., Hasekamp, O. P., Bian, H., Curci, G., Myhre, G., van Noije, T., Schulz, M., Skeie, R. B., Takemura, T., and Zhang, K.: Aerosol single-scattering albedo over the global oceans: Comparing PARASOL retrievals with AERONET, OMI, and AeroCom models estimates, J. Geophys. Res., 120, 9814-9836, https://doi.org/10.1002/2015JD023501, 2015.

Lacagnina C., Hasekamp, O. P., and Torres, O.: Direct radiative effect of aerosols based on PARASOL and OMI satellite observations, J. Geophys. Res., 122, 2366-2388, https://doi.org/10.1002/2016JD025706, 2016.

Landgraf, J. and Hasekamp, O. P.: Retrieval of tropospheric ozone: The synergistic use of thermal infrared emission and ultraviolet reflectivity measurements from space, J. Geophys. Res., 112, D08310, https://doi.org/10.1029/2006JD008097, 2007.

Langston, M., Dennis, L., Lynch, C., Roe, D., and Brown, H.: Temporal Trends in Satellite- Derived Erythemal UVB and Implications for Ambient Sun Exposure Assessment, Intl. J. Environ. Res. Public Health, 14, 176, https://doi.org/10.3390/ijerph14020176, 2017.

Lamsal, L. N., Martin, R. V., Steinbacher, M., Celarier, E. A., Bucsela, E., Dunlea, E. J., and Pinto, J.: Ground level nitrogen dioxide concentrations inferred from the satellite-borne 
Ozone Monitoring Instrument, J. Geophys. Res., 113, D16308, https://doi.org/10.1029/2007JD009235, 2008.

Lamsal, L. N., Krotkov, N. A., Celarier, E. A., Swartz, W. H., Pickering, K. E., Bucsela, E. J., Gleason, J. F., Martin, R. V., Philip, S., Irie, H., Cede, A., Herman, J., Weinheimer, A., Szykman, J. J., and Knepp, T. N.: Evaluation of OMI operational standard $\mathrm{NO}_{2}$ column retrievals using in situ and surface-based $\mathrm{NO}_{2}$ observations, Atmos. Chem. Phys., 14, 11587-11609, https://doi.org/10.5194/acp-14-11587-2014, 2014.

Lamsal, L. N., Duncan, B. N., Yoshida, Y., Krotkov, N. A., Pickering, K. E., Streets, D. G., and Lu, Z.: U.S. $\mathrm{NO}_{2}$ trends (2005-2013): EPA Air Quality System (AQS) data versus improved observations from the Ozone Monitoring Instrument (OMI), Atmos. Environ., 110, 130-143, https://doi.org/10.1016/j.atmosenv.2015.03.055, 2015.

Lamsal, L. N., Janz, S., Krotkov, N., Pickering, K. E., Spurr, R. J. D., Kowalewski, M., Loughner, C. P., Crawford, J., Swartz, W. H., and Herman, J. R.: High-resolution NO2 observations from the Airborne Compact Atmospheric Mapper: Retrieval and validation, J. Geophys. Res., 122, 1953-1970, https://doi.org/10.1002/2016JD025483, 2017.

Lean, J. L. and DeLand, M. T.: How does the Sun's spectrum vary?, J. Climate, 25, 2555-2560, https://doi.org/10.1175/JCLI-D-11$00571.1,2012$.

Lee, C., Martin, R. V., van Donkelaar, A., O’Byrne, G., Krotkov, N., Richter, A., Huey, L. G., and Holloway, J. S.: Retrieval of vertical columns of sulfur dioxide from SCIAMACHY and OMI: Air mass factor algorithm development, validation, and error analysis, J. Geophys. Res., 114, D22303, https://doi.org/10.1029/2009JD012123, 2009.

Lee, C., Martin, R. V., van Donkelaar, A., Lee, H., Dickerson, R. R., Hains, J. C., Krotkov, N., Richter, A., Vinnikov, K., and Schwab, J. J.: $\mathrm{SO}_{2}$ emissions and lifetimes: Estimates from inverse modeling using in situ and global, space-based (SCIAMACHY and OMI) observations, J. Geophys. Res., 116, D06304, https://doi.org/10.1029/2010JD014758, 2011.

Levelt, P. F., van den Oord, G. H. J., Dobber, M. R., Mälkki, A., Visser, H., de Vries, J., Stammes, P., Lundell, J., and Saari, H.: The Ozone Monitoring Instrument, IEEE T. Geosci. Remote, 44, 1093-1101, https://doi.org/10.1109/TGRS.2006.872333, 2006a.

Levelt, P. F., Hilsenrath, E., Leppelmeier, G. W., van den Oord, G. H. J., Bhartia, P. K., Tamminen, J., de Haan, J. F., and Veefkind, J. P.: Science objectives of the Ozone Monitoring Instrument, IEEE T. Geosci. Remote, 44, 1093-1101, 2006b.

Li, C., Krotkov, N. A., and Joiner, J.: OMI/Aura Sulphur Dioxide (SO2) Total Column 1-orbit L2 Swath 13×24 km V003, Greenbelt, MD, USA, Goddard Earth Sciences Data and Information Services Center (GES DISC), https://doi.org/10.5067/Aura/OMI/DATA2022, 2006.

Li, C., Zhang, Q., Krotkov, N. A., Streets, D. G., He, K., Tsay, S. C., and Gleason, J. F.: Recent large reduction in sulfur dioxide emissions from Chinese power plants observed by the Ozone Monitoring Instrument, Geophys. Res. Lett., 37, L08807, https://doi.org/10.1029/2010GL042594, 2010.

Li, C., Joiner, J., Krotkov, N. A., and Bhartia, P. K.: A fast and sensitive new satellite $\mathrm{SO}_{2}$ retrieval algorithm based on principal component analysis: Application to the ozone monitoring instrument, Geophys. Res. Lett., 40, 6314-6318, https://doi.org/10.1002/2013GL058134, 2013.
Li, C., McLinden, C., Fioletov, V., Krotkov, N. A., Carn, S. A., Joiner, J., Streets, D., He, H., Ren, X., Li, Z., and Dickerson, R. R.: India is overtaking China as the world's largest emitter of anthropogenic sulfur dioxide, Sci. Rep., 7, 14304, doi:10.1038/s41598-017-14639-8, 2017a.

Li, C., Krotkov, N., Carn, S.A., Zhang, Y., Spurr, R. J. D., and Joiner, J.: New-generation NASA Aura Ozone Monitoring Instrument (OMI) volcanic $\mathrm{SO}_{2}$ dataset: algorithm description, initial results, and continuation with the Suomi-NPP Ozone Mapping and Profiler Suite (OMPS), Atmos. Meas. Tech., 10, 445458, https://doi.org/10.5194/amt-10-445-2017, $2017 \mathrm{~b}$.

Lin, J.-T.: Satellite constraint for emissions of nitrogen oxides from anthropogenic, lightning and soil sources over East China on a high-resolution grid, Atmos. Chem. Phys., 12, 2881-2898, https://doi.org/10.5194/acp-12-2881-2012, 2012.

Lin, J.-T. and McElroy, M. B.: Detection from space of a reduction in anthropogenic emissions of nitrogen oxides during the Chinese economic downturn, Atmos. Chem. Phys., 11, 8171-8188, https://doi.org/10.5194/acp-11-8171-2011, 2011.

Lin, J.-T., Martin, R. V., Boersma, K. F., Sneep, M., Stammes, P., Spurr, R., Wang, P., Van Roozendael, M., Clémer, K., and Irie, H.: Retrieving tropospheric nitrogen dioxide from the Ozone Monitoring Instrument: effects of aerosols, surface reflectance anisotropy, and vertical profile of nitrogen dioxide, Atmos. Chem. Phys., 14, 1441-1461, https://doi.org/10.5194/acp14-1441-2014, 2014.

Ling, Z., Huang, T., Zhao, Y., Li, J., Zhang, X., Wang, J., Lian, L., Mao, X., Gao, H., and Ma, J.: OMI-measured increasing $\mathrm{SO}_{2}$ emissions due to energy industry expansion and relocation in northwestern China, Atmos. Chem. Phys., 17, 9115-9131, https://doi.org/10.5194/acp-17-9115-2017, 2017.

Liu, C., Liu, X., and Chance, K.: The impact of using different ozone cross sections on ozone profile retrievals from OMI UV measurements, J. Quant. Spectrosc. Ra., 130, 365-372, https://doi.org/10.1016/j.jqsrt.2013.06.006, 2013a.

Liu, C., Liu, Y., Liu, X., and Chance, K.: Dynamical and chemical features of a cutoff-low over northeast China in July 2007: Results from satellite measurements and reanalysis, Adv. Atmos. Sci., 30, 525-540, 2013b.

Liu, F., Zhang, Q., van der A, R. J., Zheng, B., Tong, D., Yan, L., Zheng, Y., and He, K.: Recent reduction in $\mathrm{NO}_{x}$ emissions over China: synthesis of satellite observations and emission inventories, Environ. Res. Lett., 11, 114002, https://doi.org/10.1088/1748-9326/11/11/114002, 2016a.

Liu, F., Beirle, S., Zhang, Q., Dörner, S., He, K., and Wagner, T.: $\mathrm{NO}_{x}$ lifetimes and emissions of cities and power plants in polluted background estimated by satellite observations, Atmos. Chem. Phys., 16, 5283-5298, https://doi.org/10.5194/acp16-5283-2016, $2016 \mathrm{~b}$.

Liu, F., Beirle, S., Zhang, Q., van der A, R. J., Zheng, B., Tong, D., and He, K.: $\mathrm{NO}_{x}$ emission trends over Chinese cities estimated from OMI observations during 2005 to 2015, Atmos. Chem. Phys., 17, 9261-9275, https://doi.org/10.5194/acp-179261-2017, 2017.

Liu, F., van der A, R. J., Eskes, H., Ding, J., and Mijling, B.: Evaluation of modeling $\mathrm{NO}_{2}$ concentrations driven by satellitederived and bottom-up emission inventories using in situ measurements over China, Atmos. Chem. Phys., 18, 4171-4186, https://doi.org/10.5194/acp-18-4171-2018, 2018. 
Liu, X., Bhartia, P. K., Chance, K., Spurr, R. J. D., and Kurosu, T. P.: Ozone profile retrievals from the Ozone Monitoring Instrument, Atmos. Chem. Phys., 10, 2521-2537, https://doi.org/10.5194/acp-10-2521-2010, 2010a.

Liu, X., Bhartia, P. K., Chance, K., Froidevaux, L., Spurr, R. J. D., and Kurosu, T. P.: Validation of Ozone Monitoring Instrument (OMI) ozone profiles and stratospheric ozone columns with Microwave Limb Sounder (MLS) measurements, Atmos. Chem. Phys., 10, 2539-2549, https://doi.org/10.5194/acp-102539-2010, 2010b.

Lopez, T. M., Carn, S. A., Werner, C., Kelly, P., Doukas, M., Pfeffer, M., Fee, D., Webley, P., Cahill, C., and Schneider, D. J.: Evaluation of Redoubt volcano's sulfur dioxide emissions by the Ozone Monitoring Instrument, J. Volcanol. Geoth. Res., 259, 290-307, https://doi.org/10.1016/j.jvolgeores.2012.03.002, 2013.

Lu, Z. and Streets, D. G.: Increase in NOx emissions from Indian thermal power plants during 1996-2010: Unit-based inventories and multisatellite observations, Environ. Sci. Tech., 46, 74637470, https://doi.org/10.1021/es300831w, 2012.

Lu, Z., Streets, D. G., de Foy, B., and Krotkov, N. A.: Ozone monitoring instrument observations of interannual increases in $\mathrm{SO}_{2}$ emissions from Indian coal-fired power plants during 2005-2012, Environ. Sci. Technol., 47, 13993-14000, https://doi.org/10.1021/es4039648, 2013.

Lu, Z., Streets, D. G., de Foy, B., Lamsal, L. N., Duncan, B. N., and Xing, J.: Emissions of nitrogen oxides from US urban areas: estimation from Ozone Monitoring Instrument retrievals for 2005-2014, Atmos. Chem. Phys., 15, 10367-10383, https://doi.org/10.5194/acp-15-10367-2015, 2015.

Lucas, R., Prüss-Ustün, A., and Perkins van Deventer, E.: Solar ultraviolet radiation: Assessing the environmental burden of disease at national and local levels, World Health Organization, Geneva, Switzerland, edited by: Prüss-Ustün, A. and Perkins van Deventer, E., 2010.

Lucock, M., Beckett, E., Martin, C., Jones, P., Furst, J., Yates, Z., Jablonski, N. G., Chaplin, G., and Veysey, M.: UV-associated decline in systemic folate: implications for human nutrigenetics, health, and evolutionary processes, Am. J. Hum. Biol., 29, e22929, https://doi.org/10.1002/ajhb.22929, 2016.

Marais, E. A., Jacob, D. J., Kurosu, T. P., Chance, K., Murphy, J. G., Reeves, C., Mills, G., Casadio, S., Millet, D. B., Barkley, M. P., Paulot, F., and Mao, J.: Isoprene emissions in Africa inferred from OMI observations of formaldehyde columns, Atmos. Chem. Phys., 12, 6219-6235, https://doi.org/10.5194/acp12-6219-2012, 2012.

Marais, E. A., Jacob, D. J., Wecht, K., Lerot, C., Zhang, L., Yu, K., Kurosu, T. P., Chance, K., and Sauvage, B.: Anthropogenic emissions in Nigeria and implications for ozone air quality: a view from space, Atmos. Environ., 99, 32-40, 2014.

Marchenko, S., Krotkov, N., Lamsal, L., Celarier, E., Swartz, W., and Bucsela, E.: Revising the slant column density retrieval of nitrogen dioxide observed by the Ozone Monitoring Instrument, J. Geophys. Res., 120, 5670-5692, https://doi.org/10.1002/2014JD022913, 2015.

Marchenko, S. V. and DeLand, M. T.: Solar spectral irradiance changes during Cycle 24, Astrophys. J., 789, 117, https://doi.org/10.1088/0004-637X/789/2/117, 2014.

Marchenko, S. V., DeLand, M. T., and Lean, J. L.: Solar spectral irradiance variability in Cycle 24: Obser- vations and models, J. Space Weath. Spac., 6, A40, https://doi.org/10.1051/swsc/2016036, 2016.

Marécal, V., Peuch, V.-H., Andersson, C., Andersson, S., Arteta, J., Beekmann, M., Benedictow, A., Bergström, R., Bessagnet, B., Cansado, A., Chéroux, F., Colette, A., Coman, A., Curier, R. L., Denier van der Gon, H. A. C., Drouin, A., Elbern, H., Emili, E., Engelen, R. J., Eskes, H. J., Foret, G., Friese, E., Gauss, M., Giannaros, C., Guth, J., Joly, M., Jaumouillé, E., Josse, B., Kadygrov, N., Kaiser, J. W., Krajsek, K., Kuenen, J., Kumar, U., Liora, N., Lopez, E., Malherbe, L., Martinez, I., Melas, D., Meleux, F., Menut, L., Moinat, P., Morales, T., Parmentier, J., Piacentini, A., Plu, M., Poupkou, A., Queguiner, S., Robertson, L., Rouïl, L., Schaap, M., Segers, A., Sofiev, M., Tarasson, L., Thomas, M., Timmermans, R., Valdebenito, Á., van Velthoven, P., van Versendaal, R., Vira, J., and Ung, A.: A regional air quality forecasting system over Europe: the MACC-II daily ensemble production, Geosci. Model Dev., 8, 2777-2813, https://doi.org/10.5194/gmd-8-2777-2015, 2015.

Martin, R. V.: Satellite remote sensing of surface air quality, Atmos. Environ., 42, 7823-7843, https://doi.org/10.1016/j.atmosenv.2008.07.018, 2008.

Martin, R. V., Fiore, A. M., and Van Donkelaar, A.:Spacebased diagnosis of surface ozone sensitivity to anthropogenic emissions, Geophys. Res. Lett., 31, L06120, https://doi.org/10.1029/2004GL019416, 2004.

McCormick, B. T., Edmonds, M., Mather, T. A., and Carn, S. A.: First synoptic analysis of volcanic degassing in Papua New Guinea, Geochem. Geophy. Geosy., 13, Q03008, https://doi.org/10.1029/2011GC003945, 2012.

McCormick, B. T., Edmonds, M., Mather, T., Campion, R., Hayer, C., Thomas, H. E., and Carn, S. A.: Volcano monitoring applications of the Ozone Monitoring Instrument (OMI), in: Remote Sensing of Volcanoes and Volcanic Processes: Integrating Observation and Modeling, edited by: Pyle, D. M., Mather, T. A., and Biggs, J., Geol. Soc. Lon, Special Publications, 380, https://doi.org/10.1144/SP380.11, 2013.

McLinden, C. A., Fioletov, V., Boersma, K. F., Kharol, S. K., Krotkov, N., Lamsal, L., Makar, P. A., Martin, R. V., Veefkind, J. P., and Yang, K.: Improved satellite retrievals of $\mathrm{NO}_{2}$ and $\mathrm{SO}_{2}$ over the Canadian oil sands and comparisons with surface measurements, Atmos. Chem. Phys., 14, 3637-3656, https://doi.org/10.5194/acp-14-3637-2014, 2014.

McLinden, C. A., Fioletov, V., Krotkov, N. A., Li, C., Boersma, K. F., and Adams, C.: A decade of change in $\mathrm{NO}_{2}$ and $\mathrm{SO}_{2}$ over the Canadian oil sands as seen from space, Environ. Sci. Technol., 50, 331-337, https://doi.org/10.1021/acs.est.5b04985, 2016 a.

McLinden, C. A., Fioletov, V., Shephard, M. W., Krotkov, N., Li, C., Martin, R. V., Moran, M. D., and Joiner, J.: Space-based detection of missing sulfur dioxide sources of global air pollution, Nat. Geosci., 9, 496-500, https://doi.org/10.1038/ngeo2724, 2016b.

McPeters, R. D., Bhartia, P. K., Krueger, A. J., Herman, J. R., Wellemeyer, C. G., Seftor, C. J., Jaross, G., Torres, O., Moy, L., Labow, G., Byerly, W., Taylor, S. L., Swissler, T., and Cebula, R. P.: Earth Probe Total Ozone Mapping Spectrometer (TOMS) Data Products User's Guide, NASA/TP-1998-206895, 1998.

McPeters, R. D., Frith, S., and Labow, G. J.: OMI total column ozone: extending the long-term data record, Atmos. Meas. Tech., 8, 4845-4850, https://doi.org/10.5194/amt-8-4845-2015, 2015. 
Mielonen, T., de Haan, J. F., van Peet, J. C. A., Eremenko, M., and Veefkind, J. P.: Towards the retrieval of tropospheric ozone with the Ozone Monitoring Instrument (OMI), Atmos. Meas. Tech., 8, 671-687, https://doi.org/10.5194/amt-8-671-2015, 2015.

Mijling, B. and van der A, R. J.: Using daily satellite observations to estimate emissions of short-lived air pollutants on a mesoscopic scale, J. Geophys. Res., 117, D17302, https://doi.org/10.1029/2012JD017817, 2012.

Mijling, B., van der A, R. J., and Zhang, Q.: Regional nitrogen oxides emission trends in East Asia observed from space, Atmos. Chem. Phys., 13, 12003-12012, https://doi.org/10.5194/acp-1312003-2013, 2013.

Millet, D. B., Jacob, D. J., Boersma, K. F., Fu, T.-M., Kurosu, T. P., Chance, K., Heald, C. L., and Guenther, A.: Spatial distribution of isoprene emissions from North America derived from formaldehyde column measurements by the OMI satellite sensor, J. Geophys. Res., 113, D02307, https://doi.org/10.1029/2007JD008950, 2008.

MIRADOR: MIRADOR data search tool, NASA GES-DISC, MIRADOR data search tool, available at: https://mirador.gsfc.nasa. gov/, last access: 5 April 2018.

Miyazaki, K. and Eskes, H.: Constraints on surface $\mathrm{NO}_{x}$ emissions by assimilating satellite observations of multiple species, Geophys. Res. Lett., 40, 4745-4750, https://doi.org/10.1002/grl.50894, 2013.

Miyazaki, K., Eskes, H. J., and Sudo, K.: Global $\mathrm{NO}_{x}$ emission estimates derived from an assimilation of OMI tropospheric $\mathrm{NO}_{2}$ columns, Atmos. Chem. Phys., 12, 2263-2288, https://doi.org/10.5194/acp-12-2263-2012, 2012.

Miyazaki, K., Eskes, H., Sudo, K., Boersma, K. F., Bowman, K., and Kanaya, Y.: Decadal changes in global surface $\mathrm{NO}_{x}$ emissions from multi-constituent satellite data assimilation, Atmos. Chem. Phys., 17, 807-837, https://doi.org/10.5194/acp-17-8072017, 2017.

Miyazaki, K., Sekiya, T., Fu, D., Bowman, K. W., Kulawik, S. S., Sudo, K., Walker, T., Kanaya, Y., Takigawa, M., Ogochi, K., Eskes, H., Boersam, F., Gaubert, B., Barre, J., and Emmons, L., and KORUS-AQ team: Balance of emission and dynamical controls on ozone during KORUS-AQ from multi-constituent satellite data assimilation, J. Geophys. Res.-Atmos., submitted, 2018.

Morrill, J. S., Floyd, L., and McMullin, D.: Comparison of solar UV spectral irradiance from SUSIM and SORCE, Sol. Phys., 289, 3641-3661, https://doi.org/10.1007/s11207-014-0535-5, 2014.

Müller, M., Tiefengraber, M., and Cede, A.: ESA Ground-Based Air-Quality Spectrometer Validation Network and Uncertainties Study, LuftBlick Report 2016011, Validation reports, 2017.

NASA: NASA, GES-DISC, available at: https://disc.sci.gsfc.nasa. gov/Aura/data-holdings/OMI, last access: 5 April 2018.

Novotny, E. V., Bechle, M. J., Millet, D. B., and Marshall, J. D.: National satellite-based land-use regression: $\mathrm{NO}_{2}$ in the United States, Environ. Sci. Tech., 45, 4407-4414, https://doi.org/10.1021/es103578x, 2011.

Nowlan, C. R., Martin, R. V., Philip, S., Lamsal, L. N., Krotkov, N. A., Marais, E. A., Wang, S., and Zhang, Q.: Global dry deposition of nitrogen dioxide and sulfur dioxide inferred from spacebased measurements, Global Biogeochem. Cy., 28, 1025-1043, https://doi.org/10.1002/2014GB004805, 2014.

Ortega, I., Koenig, T., Sinreich, R., Thomson, D., and Volkamer, R.: The CU 2-D-MAX-DOAS instrument - Part 1: Retrieval of
3-D distributions of $\mathrm{NO}_{2}$ and azimuth-dependent OVOC ratios, Atmos. Meas. Tech., 8, 2371-2395, https://doi.org/10.5194/amt8-2371-2015, 2015.

Pickering, K. E., Bucsela, E., Allen, D., Ring, A., Holzworth, R., and Krotkov, N.: Estimates of lightning $\mathrm{NO}_{x}$ production based on $\mathrm{OMI} \mathrm{NO}_{2}$ observations over the Gulf of Mexico, J. Geophys. Res., 121, 8668-8691, https://doi.org/10.1002/2015JD024179, 2016.

Piters, A. J. M., Boersma, K. F., Kroon, M., Hains, J. C., Van Roozendael, M., Wittrock, F., Abuhassan, N., Adams, C., Akrami, M., Allaart, M. A. F., Apituley, A., Beirle, S., Bergwerff, J. B., Berkhout, A. J. C., Brunner, D., Cede, A., Chong, J., Clémer, K., Fayt, C., Frieß, U., Gast, L. F. L., Gil-Ojeda, M., Goutail, F., Graves, R., Griesfeller, A., Großmann, K., Hemerijckx, G., Hendrick, F., Henzing, B., Herman, J., Hermans, C., Hoexum, M., van der Hoff, G. R., Irie, H., Johnston, P. V., Kanaya, Y., Kim, Y. J., Klein Baltink, H., Kreher, K., de Leeuw, G., Leigh, R., Merlaud, A., Moerman, M. M., Monks, P. S., Mount, G. H., Navarro-Comas, M., Oetjen, H., Pazmino, A., Perez-Camacho, M., Peters, E., du Piesanie, A., Pinardi, G., Puentedura, O., Richter, A., Roscoe, H. K., Schönhardt, A., Schwarzenbach, B., Shaiganfar, R., Sluis, W., Spinei, E., Stolk, A. P., Strong, K., Swart, D. P. J., Takashima, H., Vlemmix, T., Vrekoussis, M., Wagner, T., Whyte, C., Wilson, K. M., Yela, M., Yilmaz, S., Zieger, P., and Zhou, Y.: The Cabauw Intercomparison campaign for Nitrogen Dioxide measuring Instruments (CINDI): design, execution, and early results, Atmos. Meas. Tech., 5, 457-485, https://doi.org/10.5194/amt-5457-2012, 2012

Pittman, J. V., Pan, L. L., Wei, J. C., Irion, F. W., Liu, X., Maddy, E., S., Barnet, C. D., Chance, K., and Gao, R. S.: Evaluation of AIRS, IASI, and OMI ozone profile retrievals in the extratropical tropopause region using in situ aircraft measurements, J. Geophys. Res., 114, D24109, https://doi.org/10.1029/2009JD012493, 2009.

Popp, T., de Leeuw, G., Bingen, C., Brühl, C., Capelle, V., Chedin, A., Clarisse, L., Dubovik, O., Grainger, R., Griesfeller, J., Heckel, A., Kinne, S., Klüser, L., Kosmale, M., Kolmonen, P., Lelli, L., Litvinov, P., Mei, L., North, P., Pinnock, S., Povey, A., Robert, C., Schulz, M., Sogacheva, L., Stebel, K., Stein Zweers, D., Thomas, G., Tilstra, L. G., Vandenbussche, S., Veefkind, P., Vountas, M., and Xue, Y.: Development, production and evaluation of aerosol climate data records from european satellite observations (Aerosol_cci), Remote Sens., 8, 421, https://doi.org/10.3390/rs8050421, 2016.

Pour-Biazar, A., Khan, M., Wang, L, Park, Y. H., Newchurch, M. J., McNider, D., Liu, X., Byun, D., and Cameron, R.: Utilization of satellite observation of ozone and aerosols in providing initial and boundary condition for regional air quality studies, J. Geophys. Res, D18309, https://doi.org/10.1029/2010JD015200, 2011.

Prata, A. J., Carn, S. A., Stohl, A., and Kerkmann, J.: Long range transport and fate of a stratospheric volcanic cloud from Soufrière Hills volcano, Montserrat, Atmos. Chem. Phys., 7, 5093-5103, https://doi.org/10.5194/acp-7-5093-2007, 2007.

Prata, A. J., Gangale, G., Clarisse, L., and Karagulian F.: Ash and sulfur dioxide in the 2008 eruptions of Okmok and Kasatochi: Insights from high spectral resolution 
satellite measurements, J. Geophys. Res., 115, D00L18, https://doi.org/10.1029/2009JD013556, 2010

Prather, M. J. and ATom Team: The Atmospheric Tomography Experiment (ATom): Photochemistry Controlling Methane and Ozone in the Bulk Troposphere over the Remote Ocean Basins, AMS Annual Meeting, Austin, Texas, 7-11 January 2018, 4B.1, 2018.

Prud'homme, G., Dobbin, N. A., Sun, L., Burnett, R. T., Martin, R. V., Davidson, A., Cakmak, S., Villeneuve, P. J., Lamsal, L. N., van Donkelaar, A., Peters, P. A., and Johnson, M.: Comparison of remote sensing and fixed-site monitoring approaches for examining air pollution and health in a national study population, Atmos. Environ., 80, 161-171, https://doi.org/10.1016/j.atmosenv.2013.07.020, 2013.

Qu, Z., Henze, D. K., Capps, S. L., Wang, Y., Xu, X., and Wang, J.: Monthly top-down $\mathrm{NO}_{x}$ emissions for China (2005-2012): a hybrid inversion method and trend analysis, J. Geophys. Res., 122, 4600-4625, https://doi.org/10.1002/2016JD025852, 2017.

Reed, A. J., Thompson, A. M., Kollonige, D. E., Martins, D. K., Tzortziou, M. A., Herman, J. R., Berkoff, T. A., Abuhassan, N. K., and Cede, A.: Effects of local meteorology and aerosols on ozone and nitrogen dioxide retrievals from OMI and pandora spectrometers in Maryland, USA during DISCOVER-AQ 2011, J. Atmos. Chem., 72, 455-482, 2015.

Roscoe, H. K., Van Roozendael, M., Fayt, C., du Piesanie, A., Abuhassan, N., Adams, C., Akrami, M., Cede, A., Chong, J., Clémer, K., Friess, U., Gil Ojeda, M., Goutail, F., Graves, R., Griesfeller, A., Grossmann, K., Hemerijckx, G., Hendrick, F., Herman, J., Hermans, C., Irie, H., Johnston, P. V., Kanaya, Y., Kreher, K., Leigh, R., Merlaud, A., Mount, G. H., Navarro, M., Oetjen, H., Pazmino, A., Perez-Camacho, M., Peters, E., Pinardi, G., Puentedura, O., Richter, A., Schönhardt, A., Shaiganfar, R., Spinei, E., Strong, K., Takashima, H., Vlemmix, T., Vrekoussis, M., Wagner, T., Wittrock, F., Yela, M., Yilmaz, S., Boersma, F., Hains, J., Kroon, M., Piters, A., and Kim, Y. J.: Intercomparison of slant column measurements of $\mathrm{NO}_{2}$ and $\mathrm{O}_{4}$ by MAXDOAS and zenith-sky UV and visible spectrometers, Atmos. Meas. Tech., 3, 1629-1646, https://doi.org/10.5194/amt-3-16292010, 2010.

Russell, A. R., Valin, L. C., Bucsela, E. J., Wenig, M. O., and Cohen, R. C.: Space-based Constraints on Spatial and Temporal Patterns of $\mathrm{NO}_{x}$ Emissions in California, 2005-2008, Environ. Sci. Technol. 44, 3608-3615, https://doi.org/10.1021/es903451j, 2010.

Russell, A. R., Perring, A. E., Valin, L. C., Bucsela, E. J., Browne, E. C., Wooldridge, P. J., and Cohen, R. C.: A high spatial resolution retrieval of $\mathrm{NO}_{2}$ column densities from OMI: method and evaluation, Atmos. Chem. Phys., 11, 8543-8554, https://doi.org/10.5194/acp-11-8543-2011, 2011.

Russell, A. R., Valin, L. C., and Cohen, R. C.: Trends in OMI $\mathrm{NO}_{2}$ observations over the United States: effects of emission control technology and the economic recession, Atmos. Chem. Phys., 12, 12197-12209, https://doi.org/10.5194/acp-12-121972012, 2012.

SAMPO: FMI, SAMPO, available at: http://sampo.fmi.fi/, last access: 5 April 2018.

Santer, B. D., Bonfils, C., Painter, J. F., Zelinka, M. D., Mears, C., Solomon, S., Schmidt, G. A., Fyfe, J. C., Cole, J. N. S., Nazarenko, L., Taylor, K. E., and Wentz, F. J.: Volcanic con- tribution to decadal changes in tropospheric temperature, Nat. Geosci., 7, 185-189, https://doi.org/10.1038/ngeo2098, 2014.

Satheesh, S., Torres, O., Remer, L., Babu, S. S., Vinoj, V., Eck, T. F., Kleidman, R. G., and Holben, B. N.: Improved assessment of aerosol absorption using OMIMODIS joint retrieval, J. Geophys. Res., 114, D05209, https://doi.org/10.1029/2008JD011024, 2009.

Sauvage, B., Martin, R. V., van Donkelaar, A., and Ziemke, J. R.: Quantification of the factors controlling tropical tropospheric ozone and the South Atlantic maximum, J. Geophys. Res., 112, D11309, https://doi.org/1029/2006JD008008, 2007.

Sawyer, G. M., Carn, S. A., Oppenheimer, C., Tsanez, V. I., and Burton, M.: Investigation into magma degassing at Nyiragongo volcano, Democratic Republic of Congo, Geochem. Geophy. Geosy., 9, Q02017, https://doi.org/10.1029/2007GC001829, 2008.

Schenkeveld, V. M. E., Jaross, G., Marchenko, S., Haffner, D., Kleipool, Q. L., Rozemeijer, N. C., Veefkind, J. P., and Levelt, P. F.: In-flight performance of the Ozone Monitoring Instrument, Atmos. Meas. Tech., 10, 1957-1986, https://doi.org/10.5194/amt-10-1957-2017, 2017.

Schmidt, A., Leadbetter, S., Theys, N., Carboni, E., Witham, C. S., Stevenson, J. A., Birch, C. E., Thordarson, T., Turnock, S., Barsotti, S., Delaney, L., Feng, W., Grainger, R. G., Hort, M. C., Höskuldsson, Á., Ialongo, I., Ilyinskaya, E., Jóhannsson, T., Kenny, P., Mather, T. A., Richards, N. A. D., and Shepherd, J.: Satellite detection, long-range transport, and air quality impacts of volcanic sulfur dioxide from the 2014-2015 flood lava eruption at Bárðarbung (Iceland), J. Geophys. Res., 120, 9739-9757, https://doi.org/10.1002/2015JD023638, 2015.

Schoeberl, M. R., Douglass, A. R., and Joiner, J.: Introduction to special section on Aura Validation, J. Geophys. Res., 113, D15S01, https://doi.org/10.1029/2007JD009602, 2008.

Sellitto, P., Bojkov, B. R., Liu, X., Chance, K., and Del Frate, F.: Tropospheric ozone column retrieval at northern mid-latitudes from the Ozone Monitoring Instrument by means of a neural network algorithm, Atmos. Meas. Tech., 4, 2375-2388, https://doi.org/10.5194/amt-4-2375-2011, 2011.

Sigmarsson, O., Haddadi, B., Carn, S. A., Moune, S., Gudnason, J., Yang, K., and Clarisse, L.: The sulfur budget of the 2011 Grímsvötn eruption, Iceland, Geophys. Res. Lett., 40, 60956100, https://doi.org/10.1002/2013GL057760, 2013.

Sihler, H., Lübcke, P., Lang, R., Beirle, S., de Graaf, M., Hörmann, C., Lampel, J., Penning de Vries, M., Remmers, J., Trollope, E., Wang, Y., and Wagner, T.: In-operation field-of-view retrieval (IFR) for satellite and ground-based DOAS-type instruments applying coincident high-resolution imager data, Atmos. Meas. Tech., 10, 881-903, https://doi.org/10.5194/amt-10-8812017, 2017.

Silver, J. D., Brandt, J., Hvidberg, M., Frydendall, J., and Christensen, J. H.: Assimilation of $\mathrm{OMI} \mathrm{NO}_{2}$ retrievals into the limited-area chemistry-transport model DEHM (V2009.0) with a 3-D OI algorithm, Geosci. Model Dev., 6, 1-16, https://doi.org/10.5194/gmd-6-1-2013, 2013.

Singh, H. B., Brune, W. H., Crawford, J. H., Flocke, F., and Jacob, D. J.: Chemistry and transport of pollution over the Gulf of Mexico and the Pacific: spring 2006 INTEX-B campaign overview and first results, Atmos. Chem. Phys., 9, 2301-2318, https://doi.org/10.5194/acp-9-2301-2009, 2009. 
Sluis, W. W., Allaart, M. A. F., Piters, A. J. M., and Gast, L. F .L.: The development of a nitrogen dioxide sonde, Atmos. Meas. Tech., 3, 1753-1762, https://doi.org/10.5194/amt-3-1753-2010, 2010.

Sneep, M., de Haan, J., Stammes, P., Wang, P., Vanbauce, C., Joiner, J., Vasilkov, A. P., and Levelt, P. F.: Three way comparison between OMI/Aura and POLDER/PARASOL cloud pressure products, J. Geophys. Res., 113, D15S23, https://doi.org/10.1029/2007JD008694, 2008.

Solomon, S., Daniel, J. S., Neely III, R. R., Vernier, J.-P., Dutton, E. G., and Thomason, L. W.: The persistently variable "background" stratospheric aerosol layer and global climate change, Science, 333, 866-870, 2011.

Spinei, E., Carn, S. A., Krotkov, N. A., Mount, G. H., Yang, K., and Krueger, A. J.: Validation of Ozone Monitoring Instrument $\mathrm{SO}_{2}$ measurements in the Okmok volcanic cloud over Pullman, WA in July 2008, J. Geophys. Res, 115, D00L08, https://doi.org/10.1029/2009JD013492, 2010.

Stammes, P., Sneep, M., de Haan, J. F., Veefkind, J. P., Wang, P., and Levelt, P. F.: Effective cloud fractions from the Ozone Monitoring Instrument: Theoretical framework and validation, J. Geophys. Res., 113, D16S38, https://doi.org/10.1029/2007JD008820, 2008.

Stavrakou, T., Müller, J.-F., De Smedt, I., Van Roozendael, M., Kanakidou, M., Vrekoussis, M., Wittrock, F., Richter, A., and Burrows, J. P.: The continental source of glyoxal estimated by the synergistic use of spaceborne measurements and inverse modelling, Atmos. Chem. Phys., 9, 8431-8446, https://doi.org/10.5194/acp-9-8431-2009, 2009.

Stavrakou, T., Müller, J.-F., Boersma, K. F., van der A, R. J., Kurokawa, J., Ohara, T., and Zhang, Q.: Key chemical $\mathrm{NO}_{x}$ sink uncertainties and how they influence top-down emissions of nitrogen oxides, Atmos. Chem. Phys., 13, 9057-9082, https://doi.org/10.5194/acp-13-9057-2013, 2013.

Stavrakou, T., Müller, J.-F., Bauwens, M., De Smedt, I., Van Roozendael, M., De Mazière, M., Vigouroux, C., Hendrick, F., George, M., Clerbaux, C., Coheur, P.-F., and Guenther, A.: How consistent are top-down hydrocarbon emissions based on formaldehyde observations from GOME-2 and OMI?, Atmos. Chem. Phys., 15, 11861-11884, https://doi.org/10.5194/acp-1511861-2015, 2015.

Stavrakou, T., Muller, J. F., Bauwens, M., De Smedt, I., Lerot, C., Van Roozendael, M., Coheur, P. F., Clerbaux, C., Boersma, K. F., van der A, R. J., and Song, Y.: Substantial underestimation of post-harvest burning emissions in the North China Plain revealed by multi-species space observations, Sci. Rep., 6, 32307, https://doi.org/10.1038/srep32307, 2016.

Stein Zweers, D. C. and Veefkind, P.: OMI/Aura Multi-wavelength Aerosol Optical Depth and Single Scattering Albedo 1-orbit L2 Swath 13x24 km V003, Greenbelt, MD, USA, Goddard Earth Sciences Data and Information Services Center (GES DISC), https://doi.org/10.5067/Aura/OMI/DATA2001, 2012a.

Stein Zweers, D. C. and Veefkind, P.: OMI/Aura Multiwavelength Aerosol Optical Depth and Single Scattering Albedo L3 1 day Best Pixel in 0.25 degree $x \quad 0.25$ degree V3, NASA Goddard Space Flight Center, Goddard Earth Sciences Data and Information Services Center (GES DISC), https://doi.org/10.5067/Aura/OMI/DATA3004, 2012b.
Stein Zweers, D. C. and Veefkind, P.: OMI/Aura Aerosol product Multi-wavelength Algorithm Zoomed 1-Orbit L2 Swath $13 \times 12 \mathrm{~km}$ V003, Greenbelt, MD, USA, Goddard Earth Sciences Data and Information Services Center (GES DISC), https://doi.org/10.5067/Aura/OMI/DATA2003, 2012c.

Strahan, S. E. and Douglass, A. R.: Decline in Antarctic ozone depletion and lower stratospheric chlorine determined from Aura Microwave Limb Sounder observations, Geophys. Res. Lett., 44, 382-390, https://doi.org/10.1002/2017GL074830, 2017.

Streets, D. G., Canty, T., Carmichael, G. R., de Foy, B., Dickerson, R. R., Duncan, B. N., Edwards, D. P., Haynes, J. A., Henze, D. K., Houyoux, M. R., Jacob, D. J., Krotkov, N. A., Lamsal, L. N., Liu, Y., Lu, Z., Martin, R. V., Pfister, G. G., Pinder, R. W., Salawitch, R. J., and Wecht, K. J.: Emissions estimation from satellite retrievals: A review of current capability, Atmos. Environ., 77, 1011-1042, https://doi.org/10.1016/j.atmosenv.2013.05.051, 2013.

Su, S., He, J. H., Liu, Y., Wang, Y., Cai, Z., and Liu, X.: Relationships between low ozone and the longitudinal oscillation of the south Asia high over the Tibetan plateau in summer, Clim. Environ. Res., 16, 39-46, 2011.

Surono, P., Jousset, P., Pallister, J., Boichu, M., Buongiorno, M. F., Budisantoso, A., Costa, F., Andreastuti, S., Prata, F., Schneider, D., Clarisse, L, Humaida, H., Sumarti, S., Bignami, C., Griswold, J., Carn, S. A., Oppenheimer, C., and Lavigne, F.: The 2010 explosive eruption of Java's Merapi volcano - a "100-year" event, J. Volcanol. Geoth. Res., 241-242, 121-135, https://doi.org/10.1016/j.jvolgeores.2012.06.018, 2012.

Tang, Q. and Prather, M. J.: Five blind men and the elephant: what can the NASA Aura ozone measurements tell us about stratosphere-troposphere exchange?, Atmos. Chem. Phys., 12, 2357-2380, https://doi.org/10.5194/acp-12-2357-2012, 2012.

Tanskanen, A., Krotkov, N., Herman, J. R., and Arola, A.: Surface ultraviolet irradiance from OMI, IEEE T. Geosci. Remote, 44, 1267-1271, 2006.

Tanskanen, A., Lindfors, A., Määttä, A., Krotkov, N., Herman, J., Kaurola, J., Koskela, T., Lakkala, K., Fioletov, V., Bernhard, G., McKenzie, R., Kondo, Y., O’Neill, M., Slaper, H., den Outer, P., Bais, A. F., and Tamminen, J.: Validation of daily erythemal doses from Ozone Monitoring Instrument with groundbased UV measurement data, J. Geophys. Res., 112, D24S44, https://doi.org/10.1029/2007JD008830, 2007.

Tarasick, D. W., Jin, J. J., Fioletov, V. E., Liu, G., Thompson, A. M., Oltmans, S. J., Liu, J., Sioris, C. E., Liu, X., Cooper, O. R., Dann, T., and Thouret, V.: Highresolution tropospheric ozone fields for INTEX and ARCTAS from IONS ozonesondes, J. Geophys. Res., 115, D20301, https://doi.org/10.1029/2009JD012918, 2010.

Telling, J. W., Flower, V. J. B., and Carn, S. A.: A multi-sensor satellite assessment of $\mathrm{SO}_{2}$ emissions from the 2012-13 eruption of Plosky Tolbachik volcano, Kamchatka, J. Volcanol. Geoth. Res., 307, 98-106, https://doi.org/10.1016/j.jvolgeores.2015.07.010, 2015.

Theys, N., De Smedt, I., Van Roozendael, M., Froidevaux, L., Clarisse, L., and Hendrick, F.: First satellite detection of volcanic OClO after the eruption of Puyehue-Cordón Caulle, Geophys. Res. Lett. 41, 667-672, https://doi.org/10.1002/2013GL058416, 2014. 
Theys, N., De Smedt, I., van Gent, J., Danckaert, T., Wang, T., Hendrick, F., Stavrakou, T., Bauduin, S., Clarisse, L., Li, C., Krotkov, N., Yu, H., Brenot, H., and Van Roozendael, M.: Sulfur dioxide vertical column DOAS retrievals from the Ozone Monitoring Instrument: Global observations and comparison to ground-based and satellite data, J. Geophys. Res., 120, 24702491, https://doi.org/10.1002/2014JD022657, 2015.

Thomas, G. E.: Global change in the mesosphere-lower thermosphere region: Has it already arrived?, J. Atmos. Sol.-Terr. Phy., 58, 1629-1656, 1996.

Thompson, A. M., Miller, S. K., Tilmes, S., Kollonige, D. W., Witte, J. C., Oltmans, S. J., Johnson, B. J., Fujiwara, M., Schmidlin, F. J., Coetzee, G. J. R., Komala, N., Maata, M., bt Mohamad, M., Nguyo, J., Mutai, C., Ogino, S-Y., Da Silva, F. R., Paes Leme, N. M., Posny, F., Scheele, R., Selkirk, H. B., Shiotani, M., Stübi, R., Levrat, G., Calpini, B., Thouret, V., Tsuruta, H., Canossa, J. V., Vömel, H., Yonemura, S., Diaz, J. A., Tan Thanh, N. T., and Thuy Ha, H. T.: Southern Hemisphere Additional Ozonesondes (SHADOZ) ozone climatology (2005-2009): Tropospheric and tropical tropopause layer (TTL) profiles with comparisons to OMI-based ozone products, J. Geophys. Res., 117, D23301, https://doi.org/10.1029/2011JD016911, 2012.

Thompson, A. M., Stauffer, R. M., Miller, S. K, Martins, D. K., Joseph, E., Weinheimer, A. J., and Diskin, G. S.: Ozone profiles in the Baltimore-Washington region (2006-2011): satellite comparisons and DISCOVER-AQ observations, J. Atmos. Chem., https://doi.org/10.1007/s10874-014-9283-z, 2014.

Torres, O., Tanskanen, A., Veihelman, B., Ahn, C., Braak, R., Bhartia, P. K., Veefkind, P., and Levelt, P. F.: Aerosols and Surface UV Products from OMI Observations: An Overview, J. Geophys. Res., 112, D24S47, https://doi.org/10.1029/2007JD008809, 2007.

Torres, O., Jethva, H., and Bhartia, P. K.: Retrieval of aerosol optical depth above clouds from OMI observations: Sensitivity analysis and case studies, J. Atmos. Sci., 69, 1037-1053, https://doi.org/10.1175/JAS-D-11-0130.1, 2012.

Torres, O., Ahn, C., and Chen, Z.: Improvements to the OMI near-UV aerosol algorithm using A-train CALIOP and AIRS observations, Atmos. Meas. Tech., 6, 3257-3270, https://doi.org/10.5194/amt-6-3257-2013, 2013.

Torres, O.: OMI/Aura Near UV Aerosol Optical Depth and Single Scattering Albedo 1-orbit L2 Swath 13x24 km V003, Greenbelt, MD, USA, Goddard Earth Sciences Data and Information Services Center (GES DISC), https://doi.org/10.5067/Aura/OMI/DATA2004, 2006.

Torres, O.: OMI/Aura Near UV Aerosol Optical Depth and Single Scattering Albedo L3 1 day 1.0 degree x 1.0 degree V3, NASA Goddard Space Flight Center, Goddard Earth Sciences Data and Information Services Center (GES DISC), https://doi.org/10.5067/Aura/OMI/DATA3003, 2008.

Torres, O.: OMI/Aura Near UV Aerosol Optical Depth and Single Scattering Albedo Daily L2 Global Gridded 0.25 degree x 0.25 degree V3, Greenbelt, MD, USA, Goddard Earth Sciences Data and Information Services Center (GES DISC), https://doi.org/10.5067/Aura/OMI/DATA2005, 2015.

Travis, K. R., Jacob, D. J., Fisher, J. A., Kim, P. S., Marais, E. A., Zhu, L., Yu, K., Miller, C. C., Yantosca, R. M., Sulprizio, M. P., Thompson, A. M., Wennberg, P. O., Crounse, J. D., St. Clair, J. M., Cohen, R. C., Laughner, J. L., Dibb, J. E.,
Hall, S. R., Ullmann, K., Wolfe, G. M., Neuman, J. A., and Zhou, X.: Why do models overestimate surface ozone in the Southeast United States, Atmos. Chem. Phys., 16, 13561-13577, https://doi.org/10.5194/acp-16-13561-2016, 2016.

Tropospheric Emission Monitoring Internet Service (TEMIS): KNMI, TEMIS, available at: http://www.temis.nl, last access: 5 April 2018.

Tzortziou, M., Herman, J. R., Cede, A., Loughner, C. P., Abuhassan, N., and Naik, S.: Spatial and temporal variability of ozone and nitrogen dioxide over a major urban estuarine ecosystem, J. Atmos. Chem., 72, 287-309, https://doi.org/10.1007/s10874013-9255-8, 2013.

Valin, L. C., Fiore, A. M., Chance, K., and Gonzalez Abad, G.: The role of $\mathrm{OH}$ production in interpreting the variability of $\mathrm{CH}_{2} \mathrm{O}$ columns in the southeast U.S., J. Geophys. Res., 121, 478-493, https://doi.org/10.1002/2015JD024012, 2016.

van den Oord, G. H. J., Rozemeijer, N. C., Schenkelaars, V., Levelt, P. F., Dobber, M. R., Voors, R., Claas, J., de Vries, J., ter Linden, M., de Haan C., and van den Berg, T.: OMI level 0 to $1 \mathrm{~b}$ processing and operational aspects, IEEE T. Geosci. Remote, 44, 1380-1397, 2006.

van $\operatorname{der}$ A, R. J., Allaart, M. A. F., and Eskes, H. J.: Multi sensor reanalysis of total ozone, Atmos. Chem. Phys., 10, 11277-11294, https://doi.org/10.5194/acp-10-11277-2010, 2010.

van der A, R. J., Allaart, M. A. F., and Eskes, H. J.: Extended and refined multi sensor reanalysis of total ozone for the period 1970-2012, Atmos. Meas. Tech., 8, 3021-3035, https://doi.org/10.5194/amt-8-3021-2015, 2015.

van $\operatorname{der}$ A, R. J., Mijling, B., Ding, J., Koukouli, M. E., Liu, F., Li, Q., Mao, H., and Theys, N.: Cleaning up the air: effectiveness of air quality policy for $\mathrm{SO}_{2}$ and $\mathrm{NO}_{x}$ emissions in China, Atmos. Chem. Phys., 17, 1775-1789, https://doi.org/10.5194/acp17-1775-2017, 2017.

van Dingenen, R., Detener, F. J., Raes, F., Krol, M. C., Emberson, L., and Cofala. J.: The global impact of ozone on agricultural crop yields under current and future air quality legislation, Atmos. Environ., 43, 604-618, 2009.

van Geffen, J. H. G. M., Boersma, K. F., Van Roozendael, M., Hendrick, F., Mahieu, E., De Smedt, I., Sneep, M., and Veefkind, J. P.: Improved spectral fitting of nitrogen dioxide from OMI in the 405-465 nm window, Atmos. Meas. Tech., 8, 1685-1699, https://doi.org/10.5194/amt-8-1685-2015, 2015.

van Geffen, J., Van Weele, M., Allaart, M., and Van der A, R.: TEMIS UV index and UV dose operational data products, version 2, Dataset, Royal Netherlands Meteorological Institute (KNMI), https://doi.org/10.21944/temis-uv-oper-v2, 2017.

Vasilkov, A. P., Joiner, J., Spurr, R., Bhartia, P. K., Levelt, P. F., and Stephens, G.: Evaluation of the OMI cloud pressures derived from rotational Raman scattering by comparisons with other satellite data and radiative transfer simulations, J. Geophys. Res., 113, D15S19, https://doi.org/10.1029/2007JD008689, 2008.

Vasilkov, A. P., Joiner, J., Haffner, D., Bhartia, P. K., and Spurr, R. J. D.: What do satellite backscatter ultraviolet and visible spectrometers see over snow and ice? A study of clouds and ozone using the A-train, Atmos. Meas. Tech., 3, 619-629, https://doi.org/10.5194/amt-3-619-2010, 2010.

Vasilkov, A., Qin, W., Krotkov, N., Lamsal, L., Spurr, R., Haffner, D., Joiner, J., Yang, E.-S., and Marchenko, S.: Accounting for the effects of surface BRDF on satellite cloud and trace-gas re- 
trievals: a new approach based on geometry-dependent Lambertian equivalent reflectivity applied to OMI algorithms, Atmos. Meas. Tech., 10, 333-349, https://doi.org/10.5194/amt-10-3332017, 2017.

Veefkind, J. P., De Haan, J., Brinksma, E., Kroon, M., and Levelt, P.: Total ozone from the Ozone Monitoring Instrument (OMI) using the OMI-DOAS technique, IEEE T. Geosci. Remote, 44, 1239-1244, 2006.

Veefkind, J. P., Boersma, K. F., Wang, J., Kurosu, T. P., Krotkov, N., Chance, K., and Levelt, P. F.: Global satellite analysis of the relation between aerosols and short-lived trace gases, Atmos. Chem. Phys., 11, 1255-1267, https://doi.org/10.5194/acp11-1255-2011, 2011.

Veefkind, J. P., Aben, I., McMullan, K., Förster, H., de Vries, J., Otter, G., Claas, J., Eskes, H. J., de Haan, J. F., Kleipool, Q., van Weele, M., Hasekamp O., Hoogeveen R., Landgraf J., Snel R., Tol P., Ingmann P., Voors R., Kruizinga B., Vink R., Visser H., and Levelt, P.F.: TROPOMI on the ESA Sentinel-5 Precursor: A GMES mission for global observations of the atmospheric composition for climate, air quality and ozone layer applications, Remote Sens. Environ., 120, 70-83, https://doi.org/10.1016/j.rse.2011.09.027, 2012.

Veefkind, J. P., de Haan, J. F., Sneep, M., and Levelt, P. F.: Improvements to the $\mathrm{OMI} \mathrm{O}_{2}-\mathrm{O}_{2}$ operational cloud algorithm and comparisons with ground-based radar-lidar observations, Atmos. Meas. Tech., 9, 6035-6049, https://doi.org/10.5194/amt-9-60352016, 2016.

Veefkind, J. P.: OMI/Aura DOAS Total Column Ozone Zoomed 1-Orbit L2 Swath $13 \times 12 \mathrm{~km}$ V003, Goddard Earth Sciences Data and Information Services Center (GES DISC), https://doi.org/10.5067/Aura/OMI/DATA2014, 2006.

Veefkind, J. P.: OMI/Aura Cloud Pressure and Fraction (O2-O2 Absorption) 1-Orbit L2 Swath 13x24km V003, Greenbelt, MD, USA, Goddard Earth Sciences Data and Information Services Center (GES DISC), https://doi.org/10.5067/Aura/OMI/DATA2007, 2006a.

Veefkind, J. P.: OMI/Aura Ozone (O3) DOAS Total Column 1-Orbit L2 Swath 13x24 km V003, Greenbelt, MD, USA, Goddard Earth Sciences Data and Information Services Center (GES DISC), https://doi.org/10.5067/Aura/OMI/DATA2012, 2006b.

Veefkind, J. P.: OMI/Aura Cloud Pressure and Fraction (O2O2 Absorption) Zoomed 1-Orbit L2 Swath 13x12km V003, Greenbelt, MD, USA, Goddard Earth Sciences Data and Information Services Center (GES DISC), https://doi.org/10.5067/Aura/OMI/DATA2009, 2006c.

Veefkind, J. P.: OMI/Aura Cloud Pressure and Fraction (O2O2 Absorption) Zoomed 1-Orbit L2 Swath 13x12km V003, Greenbelt, MD, USA, Goddard Earth Sciences Data and Information Services Center (GES DISC), https://doi.org/10.5067/Aura/OMI/DATA1009, 2007.

Veefkind, J. P.: OMI/Aura Cloud Pressure and Fraction (O2O2 Absorption) Daily L2 Global Gridded 0.25 degree $\mathrm{x}$ 0.25 degree V3, Greenbelt, MD, USA, Goddard Earth Sciences Data and Information Services Center (GES DISC), https://doi.org/10.5067/Aura/OMI/DATA2008, 2012a.

Veefkind, J. P.: OMI/Aura Ozone (O3) DOAS Total Column Daily L2 Global Gridded 0.25 degree $x \quad 0.25$ degree V3, Greenbelt, MD, USA, Goddard Earth Sciences
Data and Information Services Center (GES DISC), https://doi.org/10.5067/Aura/OMI/DATA2013, 2012b.

Veefkind, J. P.: OMI/Aura Ozone (O3) DOAS Total Column L3 1 day 0.25 degree x 0.25 degree V3, Greenbelt, MD, USA, Goddard Earth Sciences Data and Information Services Center (GES DISC), https://doi.org/10.5067/Aura/OMI/DATA3005, 2012c.

Vernier, J. P., Thomason, L. W., Pommereau, J.-P., Bourassa, A., Pelon, J., Garnier, A., Hauchecorne, A., Blanot, L., Trepte, C., Degenstein, D., and Vargas, F.: Major influence of tropical volcanic eruptions on the stratospheric aerosol layer during the last decade, Geophys. Res. Lett., 38, L12807, https://doi.org/10.1029/2011GL047563, 2011.

Verstraeten, W. W., Neu, J. L, Williams, J. E., Bowman, K. W., Worden, J. R., and Boersma, K. F.: Rapid increases in tropospheric ozone production and export from China, Nat. Geosci., 8, 690695, https://doi.org/10.1038/ngeo2493, 2015.

Vienneau, D., de Hoogh, K., Bechle, M. J., Beelen, R., van Donkelaar, A., Martin, R. V., Millet, D. B., Hoek, G., and Marshall, J. D.: Western European land use regression incorporating satelliteand ground-based measurements of $\mathrm{NO}_{2}$ and $\mathrm{PM}_{10}$, Environ. Sci. Technol., 47, 13555-13564, 2013.

Vinken, G. C. M., Boersma, K. F., van Donkelaar, A., and Zhang, L.: Constraints on ship $\mathrm{NO}_{x}$ emissions in Europe using GEOS-Chem and OMI satellite $\mathrm{NO}_{2}$ observations, Atmos. Chem. Phys., 14, 1353-1369, https://doi.org/10.5194/acp-141353-2014, 2014a.

Vinken, G. C. M., Boersma, K. F., Maasakkers, J. D., Adon, M., and Martin, R. V.: Worldwide biogenic soil $\mathrm{NO}_{x}$ emissions inferred from $\mathrm{OMI} \mathrm{NO}_{2}$ observations, Atmos. Chem. Phys., 14, 10363 10381, https://doi.org/10.5194/acp-14-10363-2014, 2014b.

Volten, H., Brinksma, E. J., Berkhout, A. J. C., Hains, J., Bergwerff, J. B., Van der Hoff, G. R., Apituley, A., Dirksen, R. J., CalabrettaJongen, S., and Swart, D. P. J.: $\mathrm{NO}_{2}$ lidar profile measurements for satellite interpretation and validation. J. Geophys. Res., 114, D24301, https://doi.org/10.1029/2009JD012441, 2009.

Wagner, T., Beirle, S., Sihler, H., and Mies, K.: A feasibility study for the retrieval of the total column precipitable water vapour from satellite observations in the blue spectral range, Atmos. Meas. Tech., 6, 2593-2605, https://doi.org/10.5194/amt-6-25932013, 2013.

Walker, T. W., Martin, R. V., van Donkelaar, A., Leaitch, W. R., MacDonald, A. M., Anlauf, K. G., Cohen, R. C., Bertram, T. H., Huey, L. G., Avery, M. A., Weinheimer, A. J., Flocke, F. M., Tarasick, D. W., Thompson, A. M., Streets, D. G., and Liu, X.: Trans-Pacific transport of reactive nitrogen and ozone to Canada during spring, Atmos. Chem. Phys., 10, 8353-8372, https://doi.org/10.5194/acp-10-8353-2010, 2010.

Wang, H., Liu, X., Chance, K., González Abad, G., and Chan Miller, C.: Water vapor retrieval from OMI visible spectra, Atmos. Meas. Tech., 7, 1901-1913, https://doi.org/10.5194/amt-71901-2014, 2014.

Wang, H., Gonzalez Abad, G., Liu, X., and Chance, K.: Validation and update of OMI Total Column Water Vapor product, Atmos. Chem. Phys., 16, 11379-11393, https://doi.org/10.5194/acp-1611379-2016, 2016.

Wang, J., Park, S., Zeng, J., Ge, C., Yang, K., Carn, S., Krotkov, N., and Omar, A. H.: Modeling of 2008 Kasatochi volcanic sulfate direct radiative forcing: assimilation of OMI $\mathrm{SO}_{2}$ plume height data and comparison with MODIS and 
CALIOP observations, Atmos. Chem. Phys., 13, 1895-1912, https://doi.org/10.5194/acp-13-1895-2013, 2013.

Wang, L., Newchurch, M. J., Biazoor, A. P., Liu, X., Kuang, S., and Khan, M.: Evaluating AURA/OMI ozone profile retrievals using ozonesonde data and EPA surface measurements for August 2006, Atmos. Environ., 45, 5523-5530, 2011.

Wang, L., Newchurch, M. J., Pour-Biazar, A., Khan, M., Liu, X., Koshak, W., and Chance, K.: Estimating the Influence of Lightning on Upper Tropospheric Ozone Using NLDN Lightning Data and CMAQ model, Atmos. Envrion., 67, 219-228, https://doi.org/10.1016/j.atmosenv.2012.11.001, 2013.

Wang, P., Sneep, M., Veefkind, J. P., Stammes, P., and Levelt, P. F.: Evaluation of broadband surface solar irradiance derived from the Ozone Monitoring Instrument, Remote Sens. Environ., 149, 88-99, https://doi.org/10.1016/j.rse.2014.03.036, 2014.

Wang, S., Zhang, Q., Martin, R. V, Philip, S., Liu, F., Li, M., Jiang, X., and He, K.: Satellite measurements oversee China's sulfur dioxide emission reductions from coal-fired power plants, Environ. Res. Lett., 10, 114015, https://doi.org/10.1088/17489326/10/11/114015, 2015.

Wang, S. W., Zhang, Q., Streets, D. G., He, K. B., Martin, R. V., Lamsal, L. N., Chen, D., Lei, Y., and Lu, Z.: Growth in $\mathrm{NO}_{x}$ emissions from power plants in China: bottom-up estimates and satellite observations, Atmos. Chem. Phys., 12, 4429-4447, https://doi.org/10.5194/acp-12-4429-2012, 2012.

Wang, X., Mallet, V., Berroir, J.-P., and Herlin, I.: Assimilation of $\mathrm{OMI} \mathrm{NO}_{2}$ retrievals into a regional chemistry-transport model for improving air quality forecasts over Europe, Atmos. Environ., 45, 485-492, https://doi.org/10.1016/j.atmosenv.2010.09.028, 2011.

Wang, X., Heald, C. L., Sedlacek, A. J., de Sá, S. S., Martin, S. T., Alexander, M. L., Watson, T. B., Aiken, A. C., Springston, S. R., and Artaxo, P.: Deriving brown carbon from multiwavelength absorption measurements: method and application to AERONET and Aethalometer observations, Atmos. Chem. Phys., 16, 1273312752, https://doi.org/10.5194/acp-16-12733-2016, 2016.

Wargan, K., Pawson, S., Olsen, M. A., Witte, J. C., Douglass, A. R., Ziemke, J. R., Strahan, S. E., and Nielsen, J. E.: The global structure of upper troposphere-lower stratosphere ozone in GEOS-5: A multiyear assimilation of EOS Aura data, J. Geophys. Res., 120, 2013-2036, https://doi.org/10.1002/2014JD022493, 2015.

Wargan, K., Labow, G., Frith, S., Pawson, S., Livesey, N., and Partyka, G.: Evaluation of the Ozone Fields in NASA's MERRA-2 Reanalysis, J. Climate, 30, 2961-2988, https://doi.org/10.1175/JCLI-D-16-0699.1, 2017.

Witte, J. C., Douglass, A. R., da Silva, A., Torres, O., Levy, R., and Duncan, B. N.: NASA A-Train and Terra observations of the 2010 Russian wildfires, Atmos. Chem. Phys., 11, 9287-9301, https://doi.org/10.5194/acp-11-9287-2011, 2011.

Wittrock, F., Oetjen, H., Richter, A., Fietkau, S., Medeke, T., Rozanov, A., and Burrows, J. P.: MAX-DOAS measurements of atmospheric trace gases in Ny-Ålesund - Radiative transfer studies and their application, Atmos. Chem. Phys., 4, 955-966, https://doi.org/10.5194/acp-4-955-2004, 2004.

Worden, J., Liu, X., Bowman, K., Chance, K., Beer, R., Eldering, A., Gunson, M., and Worden, H.: Improved tropospheric ozone profile retrievals using OMI and TES radiances, Geophys. Res. Lett., 34, L01809, https://doi.org/10.1029/2006GL027806, 2007.
World Bank: The cost of air pollution: Strengthening the economic case for action, Tech. Rep., World Bank, available at: https://openknowledge.worldbank.org/handle/10986/25013 (last access: 5 April 2018), 2016.

World Health Organization: Ambient (outdoor) air quality and health: Fact sheet No. 313, 2014.

World Health Organization: Ambient air pollution: A global assessment of exposure and burden of disease, Tech. Rep., available at: http://apps.who.int/iris/bitstream/10665/250141/1/ 9789241511353-eng.pdf?ua=1 (last access: 5 April 2018), 2016.

Yang, K., Krotkov, N. A., Krueger, A. J., Carn, S. A., Bhartia, P. K., and Levelt, P. F.: Retrieval of large volcanic $\mathrm{SO}_{2}$ columns from the Aura Ozone Monitoring Instrument (OMI): comparison and limitations, J. Geophys. Res., 112, D24S43, https://doi.org/10.1029/2007JD008825, 2007.

Yang, K., Liu, X. Krotkov, N. A., Krueger, A. J., and Carn, S. A.: Estimating the altitude of volcanic sulfur dioxide plumes from space-borne hyper-spectral UV measurements, Geophys. Res. Lett., 36, L10803, https://doi.org/10.1029/2009GL038025, 2009a.

Yang, K., Krotkov, N. A., Krueger, A. J., Carn, S. A., Bhartia, P. K., and Levelt, P. F.: Improving retrieval of volcanic sulfur dioxide from backscattered UV satellite observations, Geophys. Res. Lett., 36, L03102, https://doi.org/10.1029/2008GL036036, 2009b.

Yang, K., Liu, X., Bhartia, P. K., Krotkov, N. A., Carn, S. A., Hughes, E. J., Krueger, A. J., Spurr, R. J. D., and Trahan, S. G.: Direct retrieval of sulfur dioxide amount and altitude from spaceborne hyperspectral UV measurements: Theory and application, J. Geophys. Res., 115, D00L09, https://doi.org/10.1029/2010JD013982, 2010.

Yang, Q., Cunnold, D. M., Wang, H.-J., Froidevaux, L., Claude, H., Merrill, J., Newchurch, M., and Oltmans, S., J.: Mid-latitude tropospheric ozone columns derived from the Aura Ozone Monitoring Instrument and Microwave Limb Sounder measurements, J. Geophys. Res., 112, D20305, https://doi.org/10.1029/2007JD008528, 2007.

Young, M. T., Bechle, M. J., Sampson, P. D., Szpiro, A. A., Marshall, J. D., Sheppard, L., and Kaufman, J. D.: Satellite-based $\mathrm{NO}_{2}$ and model validation in a national prediction model based on universal kriging and land-use regression, Environ. Sci. Technol., 50, 3686-3694, https://doi.org/10.1021/acs.est.5b05099, 2016.

Zempila, M.-M., Koukouli, M.-E., Bais, A., Fountoulakis, I., Arola, A., Kouremeti, N., and Balis, D.: OMI/Aura UV product validation using NILU-UV ground-based measurements in Thessaloniki, Greece, Atmos. Environ., 140, 2016, 283-297, 2016.

Zhang, L., Jacob, D. J., Liu, X., Logan, J. A., Chance, K., Eldering, A., and Bojkov, B. R.: Intercomparison methods for satellite measurements of atmospheric composition: application to tropospheric ozone from TES and OMI, Atmos. Chem. Phys., 10, 4725-4739, https://doi.org/10.5194/acp-10-4725-2010, 2010.

Zhang, L., Lee, C. S., Zhang, R., and Chen, L.: Spatial and temporal evaluation of long term trend (2005-2014) of OMI retrieved $\mathrm{NO}_{2}$ and $\mathrm{SO}_{2}$ concentrations in Henan Province, China, Atmos. Environ., 154, 151-166, 2017.

Zhou, Y., Brunner, D., Spurr, R. J. D., Boersma, K. F., Sneep, M., Popp, C., and Buchmann, B.: Accounting for surface reflectance anisotropy in satellite retrievals of tropospheric $\mathrm{NO}_{2}$, Atmos. 
Meas. Tech., 3, 1185-1203, https://doi.org/10.5194/amt-3-11852010, 2010.

Zhou, Y., Brunner, D., Hueglin, C., Henne, S., and Staehelin, J.: Changes in OMI tropospheric $\mathrm{NO}_{2}$ columns over Europe from 2004 to 2009 and the influence of meteorological variability, Atmos. Environ., 46, 482-495, https://doi.org/10.1016/j.atmosenv.2011.09.024, 2012.

Zhu, L., Jacob, D. J., Mickley, L. J., Marais, E. A., Cohan, D. S., Yoshida, Y., Duncan, B. N., González Abad, G., and Chance, K. V.: Anthropogenic emissions of highly reactive volatile organic compounds in eastern Texas inferred from oversampling of satellite (OMI) measurements of HCHO columns, Environ. Res. Lett., 9, 114004, https://doi.org/10.1088/17489326/9/11/114004, 2014.

Zhu, L., Jacob, D. J., Kim, P. S., Fisher, J. A., Yu, K., Travis, K. R., Mickley, L. J., Yantosca, R. M., Sulprizio, M. P., De Smedt, I., González Abad, G., Chance, K., Li, C., Ferrare, R., Fried, A., Hair, J. W., Hanisco, T. F., Richter, D., Jo Scarino, A., Walega, J., Weibring, P., and Wolfe, G. M.: Observing atmospheric formaldehyde ( $\mathrm{HCHO})$ from space: validation and intercomparison of six retrievals from four satellites (OMI, GOME2A, GOME2B, OMPS) with SEAC ${ }^{4}$ RS aircraft observations over the southeast US, Atmos. Chem. Phys., 16, 1347713490, https://doi.org/10.5194/acp-16-13477-2016, 2016.

Zhu, L., Jacob, D. J., Keutsch, F. N., Mickley, L. J., Scheffe, R., Strum, M., González Abad, G., Chance, K., Yang, K., Rappenglück, B., Millet, D. B., and Baasandorj, M.: Formaldehyde (HCHO) as a Hazardous Air Pollutant: Mapping surface air concentrations from satellite and inferring cancer risks in the United States, Environ. Sci. Technol., 51, 5650-5657, https://doi.org/10.1021/acs.est.7b01356, 2017.

Ziemke, J. R., Chandra, S., and Bhartia, P. K.: Two new methods for deriving tropospheric column ozone from TOMS measurements: The assimilated UARS MLS/HALOE and convectivecloud differential techniques, J. Geophys. Res., 103, 2211522127, https://doi.org/10.1029/98JD01567, 1998.

Ziemke, J. R., Chandra, S., Duncan, B. N., Froidevaux, L., Bhartia, P. K., Levelt, P. F., and Waters, J. W.: Tropospheric ozone determined from Aura OMI and MLS: Evaluation of measurements and comparison with the Global Modeling Initiative's Chemical Transport Model, J. Geophys. Res., 111, D19303, https://doi.org/10.1029/2006JD007089, 2006.
Ziemke, J. R., Joiner, J., Chandra, S., Bhartia, P. K., Vasilkov, A., Haffner, D. P., Yang, K., Schoeberl, M. R., Froidevaux, L., and Levelt, P. F.: Ozone mixing ratios inside tropical deep convective clouds from OMI satellite measurements, Atmos. Chem. Phys., 9, 573-583, https://doi.org/10.5194/acp-9-573-2009, 2009.

Ziemke, J. R., Chandra, S., Oman, L. D., and Bhartia, P. K.: A new ENSO index derived from satellite measurements of column ozone, Atmos. Chem. Phys., 10, 3711-3721, https://doi.org/10.5194/acp-10-3711-2010, 2010.

Ziemke, J. R., Olsen, M. A., Witte, J. C., Douglass, A. R., Strahan, S. E., Wargan, K., Liu, X., Schoeberl, M. R., Yang, K., Kaplan, T. B., Pawson, S., Duncan, B. N., Newman, P. A., Bhartia, P. K., and Heney, M. K.: Assessment and applications of NASA ozone data products derived from Aura OMI/MLS satellite measurements in context of the GMI Chemical Transport Model, J. Geophys. Res., 119, 5671-5699, https://doi.org/10.1002/2013JD020914, 2014.

Ziemke, J. R., Douglass, A. R., Oman, L. D., Strahan, S. E., and Duncan, B. N.: Tropospheric ozone variability in the tropics from ENSO to MJO and shorter timescales, Atmos. Chem. Phys., 15, 8037-8049, https://doi.org/10.5194/acp-15-8037-2015, 2015.

Zoogman, P., Liu, X., Suleiman, R., M., Pennington, W. F., Flittner, D. E., Al-Saadi, J. A., Hilton, B. B., Nicks, D. K., Newchurch, M. J., Carr, J. L., Janz, S. J., Andraschko, M. R., Arola, A., Baker, B. D., Canova, B. P., Chan Miller, C., Cohen, R. C., Davis, J. E., Dussault, M. E., Edwards, D. P., Fishman, J., Ghulam, A., González Abad, G., Grutter, M., Herman, J. R., Houck, J., Jacob, D. J., Joiner, J., Kerridge, B. J., Kim, J., Krotkov, N. A., Lamsal, L., Li, C., Lindfors, A., Martin, R. V., McElroy, C. T., McLinden, C., Natraj, V., Neil, D. O., Nowlan, C. R., O’Sullivan, E. J., Palmer, P. I., Pierce, R. B., Pippin, M. R., Saiz-Lopez, A., Spurr, R. J. D., Szykman, J. J., Torres, O., Veefkind, J. P., Veihelmann, B., Wang, H., Wang, J., and Chance, K.: Tropospheric emissions: Monitoring of pollution (TEMPO), J. Quant. Spectrosc. Ra., 1739, https://doi.org/10.1016/j.jqstt.2016.05.008, 2016. 